\title{
Articles
}

\section{The Uneasy Relationship Between \\ Criminal Procedure and Criminal Justice}

\author{
William J. Stuntz ${ }^{\dagger}$
}

\section{CONTENTS}

I. Defendants' Rights and the State's Resources . . . . . . . . 6

A. Courts' Domain, Legislatures' Domain . . . . . . . . . . 6

B. Criminal Procedure as an Incomplete Regulatory System . . . 12

II. How CRIMINAL Litigation Is Rationed (and how Criminal Procedure Changes IT) $\ldots \ldots \ldots \ldots .22$

A. The Prosecution ...................... 23

1. Crime Rates and the Level of Prosecurion ... . . . . . 23

2. Defendants' Wealth and the Cost of Prosecution ..... . 27

B. The Defense ....................... 31

1. Underlitigation .................. 32

2. Differently Distributed Litigation ........... 35

a. Why Some Claims Displace Others .......... 35

b. Procedural Claims and Factual Claims ... . . . . 37

C. Reacting to the Defense: The Prosecution (Continued) . . . . 45

$\doteqdot$ Class of 1962 Professor and Horace W Goldsmith Research Professur. Universily ut Virginia School of Law. I am grateful to a long list of readers of earlier drafts who offered helplul comments Ken Abraham, Bruce Ackerman, Akhil Amar, lan Ayres, Anne Coughlın. John Hamson, Juhn Jellnies. Mlike Klarman, Stanton Krauss, John Langbein, Peler Schuck, and Eltzabeth Scoll Special thankes are due to Daniel Richman, Mike Seidman, and Carol Stekker, their detalled cnttctsms enormuusly atded and influenced my thinking. For useful discussions, I thank participants in workshops at Comell Luw Schowl. Northwestem University School of Law, Quinniplac College of Law. and Yale Law Schoul. along with participants in the Virginia Constitutuonal Law Workshop and the Constututuonal Law Collogutum at Siew York University. Last but not least, I thank Alıson Siegler. Ken Sugarman. and Chnsune Tellı lor tıne research assistance. Errors and omissions are mine, not theirs 
D. Distribution, Discretion, and Discrimination

III. Defining CRiminal Procedure . . . . . . . . . . . 52

A. The Structure of the System . . . . . . . . . . . . 53

B. Legislatures' Incentives . . . . . . . . . . . . . 55

C. Appellate Courts' Perceptions . . . . . . . . . . . . 60

IV. A Different Constitutional Path: Substance AND Funding . 65

V. Conclusion $\ldots \ldots \ldots \ldots \ldots \ldots \ldots \ldots \ldots \ldots \ldots \ldots$ 
Most talk about the law of criminal procedure treats that law as a selfcontained universe. The picture looks something like this: The Supreme Court says that suspects and defendants have a right to be free from certain types of police or prosecutorial behavior. Police and prosecutors, for the most par, then do as they're told. When they don't, and when the misconduct is tied to criminal convictions, the courts reverse the convictions, thereby sending a message to misbehaving officials. Within the bounds of this picture there is room for a lot of debate about the wisdom or constitutional pedigree of particular doctrines, and the literature is filled with debate of that sor. ' There is also room for theorizing about the optimal specificity of the rules the Supreme Court creates; the literature contains some of that, though less than it should. ${ }^{2}$ Finally, there is room for arguing about remedies-about whether reversing criminal convictions is an appropriate means of getting the police, prosecutors, and trial judges to do what the law says they ought to do. At least in the sphere of Fourth and Fifth Amendment law, a lively debate along those lines exists. ${ }^{3}$ But for all their variety, these debates take for granted the same basic picture of the process, a process whose only variables are the rules themselves and the remedies for their violation.

The picture is, of course, wrong. Criminal procedure's rules and remedies are embedded in a larger system, a system that can adjust to those rules in ways other than obeying them. And the rules can in turn respond to the system

1. Until recently, the literature has been more concemed with the law's wisdom, with whether the rules made sense, than with its constitutional pedigree. That seems to have changed The past few years have seen an outpouring of work on the origins and histoncal development of Fourth. Fifth. and Sixth Amendment doctrine, so much so that history is becoming the dominant subject malter in criminal

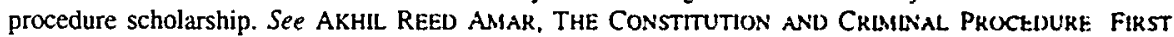
PRINCIPLES (1997); R.H. HelMHOLZ ET AL., The PRIVILEGE AGALNST SELF-INCRLMLNatION ITS ORIGLSS AND DEvelopment (1997); Morgan Cloud. The Fourh Anendment Durng the Lochner Era. Prnan. Property, and Liberty in Constitutional Theon, 48 STAN L REV 555 (1996). Tracey Maclin. The Central Meaning of the Fourth Amendment. 35 WM. \& MARY L REv 197 (1993). Willam J StuniL. The Substantive Origins of Criminal Procedure, 105 YALE L.J 393 (1995): Morgin Cloud, Searching Throught History; Searching for Histon;, 63 U. CHI. L. REV 1707 (1996) (book review)

2. The best work remains a pair of classic anteles from over iwo decades ago Anthony $G$ Amsterdam, Perspectives on the Fourh Amendmen, 58 MLN. L REv 349 (1974). and Wayne R Lafave. "Case-by-Case Adjudication" Versus "Standardized Procedures". The Robinson Dilenuna. 1974 SUP CT REV. 127.

3. The full literature on the exclusionary rule is much too lange to cute In the past few years. that literature has focused on the merits of a series of arguments. mostly but not enturely histoncal. advanced by Akhil Amar, who is currently the exclusionary rule's leading cnuc For Amar's work on the subject, see Akhil Reed Amar, Against Exclusion (Except so Prosect Truth or Prevent Privact Violations), $20 \mathrm{HakV}$ J.L. \& PUB. POL'Y 457 (1997); Akhil Reed Amar \& Rence B Letlow. Fifth Amendment First Principles The Self-Incrimination Clause, $93 \mathrm{MICH}$. L. REV. 857 (1995), and Akhul Reed Amar, Fourth Amendment First Principles, 107 HARv. L. REv. 757 (1994). For responses. soc Donald A Dnpps, Atlul Amar on Criminal Procedure and Constitutional Law: "Here / Go Down That Wrong Road Agan." 74 N C L ReV 1559 (1996); Yale Kamisar, On the "Fruits" of Miranda Violastons, Coerced Confessions, and Compelled Testimony, $93 \mathrm{MICH}$. L. REV. 929 (1995); Tracey Maclın. When the Cure for the Fourth Amendment is Worse Than the Disease, 68 S. CAL. L. REV. 1 (1994); and Carol S Steker. Second Thoughts About First Principles, 107 HARV. L. Rev. 820 (1994). For a more ambivalent discussion of the ments of the exclusionary rule, see William J. Stuntz, The Virtues and Vices of the Exchusionary Rule. $20 \mathrm{HakV} \mathrm{J} \mathrm{L}$ \& PUB. POL'Y 443 (1997). 
in a variety of ways, not all of them pleasant. The more one focuses on that dynamic, the more problematic the law of criminal procedure seems.

The heart of the problem is the system's structure. The criminal justice system is dominated by a trio of forces: crime rates, the definition of crime (which of course partly determines crime rates), and funding decisions-how much money to spend on police, prosecutors, defense attorneys, judges, and prisons. These forces determine the ratio of crimes to prosecutors and the ratio of prosecutions to public defenders, and those ratios in turn go far toward determining what the system does and how the system does it. But the law that defines what the criminal process looks like, the law that defines defendants' rights, is made by judges and Justices who have little information about crime rates and funding decisions, and whose incentives to take account of those factors may be perverse. High crime rates make it easy for prosecutors to substitute cases without strong procedural claims for cases with such claims. Underfunding of criminal defense counsel limits the number of procedural claims that can be pressed. Both phenomena make criminal procedure doctrines seem inexpensive to the appellate judges who define those doctrines. Unsurprisingly, given that regulating the criminal justice system has seemed cheap, the courts have done a lot of regulating-more, one suspects, than they would have done in a world where defendants could afford to litigate more often and more aggressively, or where prosecutors could not so easily substitute some cases for others. Criminal procedure is thus distorted by forces its authors probably do not understand.

The distortion runs both ways. As courts have raised the cost of criminal investigation and prosecution, legislatures have sought out devices to reduce those costs. Severe limits on defense funding are the most obvious example, but not the only one. Expanded criminal liability makes it easier for the government to induce guilty pleas, as do high mandatory sentences that serve as useful threats against recalcitrant defendants. And guilty pleas avoid most of the potentially costly requirements that criminal procedure imposes. These strategies would no doubt be politically attractive anyway, but the law of criminal procedure makes them more so. Predictably, underfunding, overcriminalization, and oversentencing have increased as criminal procedure has expanded.

Nor are the law's perverse effects limited to courts and legislatures. Constitutional criminal procedure raises the cost of prosecuting wealthier defendants by giving those defendants more issues to litigate. The result, at the margin, is to steer prosecutors away from such defendants and toward poorer ones. By giving defendants other, cheaper claims to raise, constitutional criminal procedure also raises the cost to defense counsel of investigating and litigating factual claims, claims that bear directly on their clients' innocence or guilt. The result is to steer defense counsel, again at the margin, away from those sorts of claims and toward constitutional issues. More Fourth, Fifth, and 
Sixth Amendment claims probably mean fewer self-defense claims and mens rea arguments. This turns the standard conservative criticism of the law of criminal procedure on its head. Ever since the 1960s, the right has argued that criminal procedure frees too many of the guilty. The better criticism may be that it helps to imprison too many of the innocent.

It also does little about the concern that, more than anything else, prompted its creation. The post-1960 constitutionalization of criminal procedure arose, in large part, out of the sense that the system was treating black suspects and defendants much worse than white ones. Warren-era constitutional criminal procedure began as a kind of antidiscrimination law * But the criminal justice system is characterized by extraordinary discretion - over the definition of crimes (legislatures can criminalize as much as they wish), over enforcement (police and prosecutors can arrest and charge whom they wish), and over funding (legislatures can allocate resources as they wish). In a system so dominated by discretionary decisions, discrimination is easy, and constitutional law has surprisingly little to say about it.

To some degree, these problems are the product of a particular set of contingent circumstances. Vary the circumstances, and the problems would look quite different. For example, we may someday return to the very low crime-to-prosecutor ratios of the early 1960s, either because crime takes a nosedive or because criminal justice budgets go through the roof (or both). If that happens, prosecutorial discretion will seem less important, for prosecutors will be able to pursue all strong cases and a good number of weak ones. Guilty plea rates will fall as the proportion of contestable cases rises. More trials will mean that the cost of constitutional regulation in this area will become more visible to judges, which might lead the Supreme Court to alter the regulation in important ways. This is just one set of speculations about one possible scenario; other scenarios, pushing prosecutors and courts in very different directions, could easily be spun out. The lesson seems clear: Generalizing is dangerous, for the problems that afflict the system today are the consequence of today's facts and today's law, and both facts and law are certain to change.

Yet some cautious generalizing is still possible. In a legislatively funded system with state-paid prosecutors and defense attorneys, judge-made procedural rights are bound to have some perverse effects, pushing prosecutors and defense attorneys and legislators and even the judges themselves in uncomfortable directions. The effects are impossible to measure, and they will be larger or smaller depending on background circumstances. But they remain real, and inevitable.

4. This observation is most often made about Fourth Amendment law See, e g. Jokn HakT ELY, DEMOCRACY AND DISTRUST 97 (1980); Steiker, supra note 3, at 841 -4 for an argument that the point holds more broadly, see Michael J. Klarman. The Puziling Resesfance to Polincal Process Theorn. T7 VA L. REV. $747,753-66$ (1991). 
Interestingly, judicial intervention in other aspects of the criminal justice system-the definition of crimes and the funding of criminal defense-does not seem likely to have these sorts of perverse effects. Constitutionalizing procedure, in a world where substantive law and funding are the province of legislatures, may tend to encourage bad substantive law and underfunding. But constitutionalizing some aspects of substantive criminal law and defense funding would not tend to encourage bad procedure, or bad anything else. Yet substance and funding are the areas where courts have most deferred to legislatures, where passivity rather than activism has been the judicial norm. It may be that the broad structure of constitutional regulation of criminal justice has it backward, that courts have been not too activist, but activist in the wrong places.

The balance of this Article is organized as follows. Part I discusses the twin sources of the problem: the allocation of power between the criminal justice system's two bosses-courts and legislatures-and the nature of the law of constitutional criminal procedure. Part II discusses how criminal litigation is rationed in a system with public prosecutors and state-paid defense counsel, and how that rationing process changes the effect of the constitutional rules that govern criminal procedure. Part III suggests that courts and legislatures are locked into a perverse dynamic, that the existing system pushes appellate courts to make too much (and the wrong kind of) law, which in turn pushes legislatures to fund criminal defense too stingily and to define substantive criminal law too broadly. Part IV briefly raises the possibility of a different sort of constitutional regulation, one focused more on criminal substance and the funding of defense counsel and less on the details of criminal procedure. These discussions are sketchy and speculative; the goal is to begin an argument, not to end one. They are also one-sided: My aim is to suggest that constitutional criminal procedure has substantial unappreciated costs; I do not discuss its (better appreciated) benefits, which may also be substantial. The argument thus does not lead to any confident bottom line. It does, however, undermine what seems to be the confident bottom line of most judges and most academics in the field-that the current approach to constitutional law and criminal justice is unambiguously sound.

\section{DefENDANTS' RIGHTS AND THE STATE'S RESOURCES}

\section{A. Courts' Domain, Legislatures' Domain}

Criminal procedure is, basically, a subset of constitutional law. That is why the criminal procedure literature focuses so thoroughly on the latest Supreme Court cases-in this area, the Supreme Court makes the relevant policy judgments, albeit with some fleshing out by other federal and state appellate courts. And once made, those judgments stick. 
Or do they? Consider the effects of two other variables, both of which legislatures control and both of which go far toward defining what the law of criminal procedure means on the ground. The first is the scope of criminal liability. Broader substantive criminal law allows the state to end-run much of criminal procedure. ${ }^{5}$ In a world where trivial crimes stay on the books, or one where routine traffic offenses count as crimes, the requirement of probable cause to arrest may mean almost nothing. Officers can arrest for a minor offense-everyone violates the traffic rules-in order to search or question a suspect on a major one. ${ }^{6}$ This allows arrests and searches of suspected drug dealers without any ex ante support for the suspicion, the very thing the probable cause standard is supposed to forbid. In a world where sodomy laws remain valid long after their enforcement has ceased, prosecutors can induce guilty pleas in some problematic sexual assault cases-the need to prove nonconsent disappears, and with it (again, in some cases) the ability to mount a plausible defense. This amounts to convicting defendants of sexual assault without proving the crime, by pointing to another crime that serves as the excuse for punishment, but not the reason.

Notice that procedural constraints on police and prosecutors actually encourage the government to behave in this fashion. One of the govemment's biggest gains from overcriminalization is the ability to avoid costly criminal procedure doctrines. Traffic "crimes" reduce the cost of the probable cause requirement, just as no-longer-enforced sodomy laws reduce the cost of the beyond-a-reasonable-doubt standard of proof. Those criminal procedure doctrines thus raise the government's incentive to overcriminalize. Not only can the state get around inconvenient constitutional limits by expanding criminal law's scope; the limits themselves tend, at the margin, to induce the expansion. These effects do not cover the whole of criminal litigation. But the pair of examples offered above (and there are many others) shows how thoroughly a state's definition of its criminal law can undermine important parts of criminal procedure.

Which leads to the second variable legislatures control: They fund the system. Legislatures decide how many police officers, prosecutors, and judges to have, and how much to pay them. They also decide how generously to fund criminal defense counsel in those cases (the majority) ${ }^{7}$ in which the court

5. The balance of this paragraph sketches an argument developed in more detall in Willum J Stunle. Substance, Process, and the Civil-Criminal Line, 7 J. CONTEMP LEGAL IssuES I (1996)

6. See Whren v. United States, 116 S. Cl. 1769 (1996) (holding that police can detain motonsts where there is probable cause to believe that they have volaled traffic laws, regardless of whether the stop is pretextual).

7. According to the Bureau of Jusuce Stausucs, the "generally accepled indigency rate" lor state felony cases in the early 1980s was 48\%. Bureau of Justice Statistics. US Dep'T of Justick. Niational CRIMINAL DEFENSE SYSTEMS STUDY 33 (1986). In 1962, the comparable tigure was $43 \%$ See Lit Silverstein, Defense of the Poor in Criminal Cases in american Statt: CuUkts a Fitlo Study AND REPORT 7-8 (1965). By 1992, the comparable figure was almost $80 \%$ See Steven $K$ Smith \& Carol J. DeFrances, Indigent Defense, Bureau Just. STat Selected Findings. Feb 1996, at 1 , 4 
appoints counsel.

Over the course of the past couple of decades, legislatures have exercised this funding power to expand substantially the resources devoted to law enforcement, though the budget increases appear less substantial in light of parallel increases in crime. In constant dollars, total state and local expenditures for prosecution and other government legal services trebled between 1971 and $1990 ;^{8}$ expenditures for police rose $60 \% .^{9}$ During the same period, the number of index crimes (a figure that includes, basically, murder, rape, robbery, arson, aggravated assault, and serious theft offenses) rose nearly $70 \%{ }^{10}$-and that increase followed the $1960 \mathrm{~s}$, when such crimes rose more than $187 \% .^{11}$ Those figures do not include drug offenses, which by 1990

8. See Bureau of Justice Statistics, U.S. Dep't of Justice, Sourcebook on Criminal JusticE-1993, at 3 tbl.1.3 (Kathleen Maguire \& Ann L. Pastore eds., 1994) (hereinafter 1993 SOURCEBOOKJ (showing an $889 \%$ rise in state and local expenditures on prosecution and legal services, excluding public defense); U.S. DEP'T OF COMMERCE, STATISTICAL ABSTRACT OF THE UNITED STATES-1996, at 483 (1996) [hereinafter 1996 STATISTICAL ABSTRACT] (showing that inflation during the same period was $223 \%$ ). This increase overstates the rise in expenditures on criminal prosecution. Stute expenditures rose faster than those of local government, see 1993 SOURCEBOOK, supra, at 3 tbl.1.3, but the mass of criminal cases were and are prosecuted by local officials.

9. See 1993 SouRCEBOOK, supra note 8, at 3 tbl.1.3 (stating that state and local expenditures on police rose $418 \%$ ). The figure in the text is discounted for inflation. See 1996 STaTISTICAL ABSTRACT, supra note 8 , at 483 .

10. Compare FBI, UNiform CRIME REPorts For the UNITEd STATEs-1980, at 41 tbl.2 (1981) [hereinafter 1980 UNIFORM CRIME REPORTS] (showing 8.6 million index crimes in 1971), with FBI, UNIFORM CRIME REPORTS FOR THE UNITED STATES-1991, at 5 (1992) [hereinafter 1991 UNIFORM CRIME REPORTS] (showing 14.5 million index crimes in 1990).

The National Crime Victimization Survey tells a different story; according to that survey, crime-not just crime rates, but crime-actually declined between 1973 and 1990. See BUREAU OF JUSTICE STATISTICS, U.S. DeP'T OF Justice, CRIMINAL Victimization IN THE UNITED STATES: 1973-90 TRENdS 9 tbl.l (1992) [hereinafter CRIMINAL VICTIMIZATION]. I have two reasons for using the FBI data rather than the estimates provided by the victimization surveys. First, the FBI data are based on crime reports, which are likely to correlate fairly strongly with cases presented to prosecutors for further action. Because the effect of criminal procedure on prosecutors and defense lawyers depends more on the number of criminal cases than on the number of crimes, this makes crime reports a more useful source than after-the-fact victim surveys.

The second reason is more speculative. The victimization surveys conflict with a number of other indicators of crime-not only the number of crimes reported to the police, but numbers of artests, felony prosecutions, and convictions as well. Each of those figures rose sharply during the relevant time period. Arrests rose $48 \%$ from 1976 to 1990. Compare BUREAU OF JUSTICE STATISTICS, U.S. DEP'T OF JUSTICE, SOURCEBOOK ON CRIMNAL JuSTICE-1978, at 478 tbl.4.1 (Nicolette Parisi et al. eds., 1979), with BUREAU of Justice Statistics, U.S. DEP'T OF JUSTICE, SOURCEBOOK ON CRIMINAL JustiCE-1991, at 432 tbl.4.1 (1992) [hereinafter 1991 SOURCEBOOK]. Felony filings by state and local prosecutors more than doubled from 1978 to 1991. See infra note 19. State court felony convictions rose 53\% from 1986 to 1992 (pre1986 data does not allow for good cross-time comparison). Compare BUREAU OF JUSTICE STATISTICS, U.S. DEP'T OF JUSTICE, FELONY SENTENCES IN STATE COURTS, 1986, at 2 tbl.1 (1989), with Bureau of Justice STATistics, U.S. DEP'T OF JUSTICE, FELONY SENTENCES IN STATE COURTS, 1992, at 2 tbl.1 (1995). All these indicators are in some tension with flat or declining crime through the $1970 \mathrm{~s}$ and $1980 \mathrm{~s}$. To be sure, it is possible that the rise in arrests and prosecutions reflects both greater efficiency on the part of police and prosecutors and a greater desire to "crack down" on criminals, and that crime rates werc declining even while arrest, prosecution, and conviction rates were rising. But the magnitude of this supposed efficiency gain is, at the least, surprising; it requires some account of why police, prosccutors, and courts all sought to punish a steadily and substantially higher proportion of criminals through the $1970 \mathrm{~s}$ and 1980s. The more natural assumption is that increases in crime generated at least some of the increases in arrests, prosecutions, and convictions.

11. See FBI, UNIFORM CRIME REPORTS FOR THE UNITED STATES-1972, at 61 tbl.2 (1972) [hereinafter 1972 UNIFORM CRME REPORTS]. 
accounted for one-third of all state felony convictions; ${ }^{12}$ two decades earlier, drugs had been a small part of prosecutors' dockets. ${ }^{13}$ The overall picture is of prosecutorial budgets that have outstripped the rise in crime during the 1970 s and 1980s, coupled with police budgets that have not. On the other hand, though comparable budget data on the 1960s are hard to come by, it seems unlikely that either police or prosecutors' offices have kept pace with the huge rise in crime since the early 1960s. ${ }^{14}$

Criminal defense has been treated both more and less generously. Budgets in the early 1970s saw enormous percentage increases, but from a very low baseline. ${ }^{15}$ By the late 1970 s, the increases had slowed considerably. Total spending on indigent defense rose slightly more than $60 \%$ in constant dollars between 1979 and $1990 ;^{16}$ state and local spending on indigents roughly doubled. ${ }^{17}$ Meanwhile, the percentage of cases in which defendants were given appointed counsel was also rising, from just under half in the late 1970s and early 1980 s to $80 \%$ by $1992 .{ }^{18}$ And the total number of criminal cases was rising as well: State court felony filings more than doubled between 1978 and $1990 .^{19}$ Thus, notwithstanding nominal budget increases, spending on

12. See 1993 SOURCEBOOK, supra note 8 , at 535 thl 555

13. Drug cases comprised less than 5\% of stale commal charges in 1971 See BUktau of Justict: STATISTICS, U.S. DEP'T OF JUSTICE, SOURCEBOOK ON CRIMINAL JUSTICE-1973. al 325 tbl 532 (1973) [hereinafter 1973 SOURCEBOOK]. Data on the percentage of feluny drug convictions for 1971 or thereabouts is unavailable. Another indication of the growth in importance of drug cases is the number of drug artests. which more than quintupled from 1968 to 1988. See Roben Reinhold. Police, Hard Pressed in Drug War. Are Tuming to Preventive Efforts, N.Y. TMMES. Dec 28. 1989. At Al (reporting that Justlce Depanment statistics show arrests for drug violations rising from 162.177 in 1968 (0 850.034 in 1988)

14. I am unaware of any nationwide data on state and local expenditures on cnminal prosecution during the 1960s. Presumably budgets rose somewhat dunng the course of that dectede li seems unlukely. however, that they rose even close to proponionatcly with the rase in senous crime. FBI index crmes nearly trebled from 1961 to 1971 . See supra notes 10-11 and accompanying text Absent good data, the safest assumption is that budgets fell far behind crime increases in the 1960s, and the lange inereases of the 1970 s were designed to catch up. The increases would have accomplished that purpose had drug cnme not steeply increased during the 1970 s and 1980s.

15. Compare 1973 SOURCEBOOK, supra note 13, at 24 tbl 12 (stating that state and local expenditures on public defense in 1970 were $\$ 46$ million), wh/ BUREAU OF JUSTICE STATISTICS, U S DE:P'T Or JUSTICE. SOURCEBOOK ON CRIMINAL JUSTICE-1980, at 7 tbl.1 4 (lisung the comparable figure for 1978 as 5315 million).

16. See 1993 SOURCEBOOK, supra note 8, at 3 thl 13 (showing an increase in total spending on indigent defense of $192 \%$ between 1979 and 1990). The consumer price index rose 80\% Junng the same period. See 1996 STATISTICAL ABSTRACT, supra nole 8, at 483

17. State and local spending on indigent defense increased $274 \%$ in nominal dollars during the same period. See 1993 SouRCEBOOK, supra note 8 , at 3 tbl.1.3 Given the inflation figures stated supra note 16. in constant dollars the increase was $108 \%$.

18. See supra note 7.

19. Compare National CTR. for State Courts, State Court Caseload Statistics anival REPORT 1984, at 189-90 bl.35 (1986) [hereinafter 1984 CASElOAD STATISTICS) (showing a 36\% increase in felony filings from 1978 to 1984), with NATIONAL CTR. FOR STATE COURTS. STATE COUKT CASELOAD STATISTICS: ANNUAL REPORT 1991, at 37 tbl.1.25 (1993) [heremafter 1991 CASELOAD STATISTICS] (showing a $51 \%$ increase in felony filings from 1985 to 1991). If filings were constant from 1984 to 1985. this would mean a $105 \%$ increase from 1978 to 1991 . The increase was probably greater, as the number of filings was growing especially rapidly in the mid-1980s See 1991 CASELOAD STATISTICS, supra. at 37 tbl.1.25 (showing a $10 \%$ increase from 1985 to 1986) 
indigent defendants in constant dollars per case appears to have declined significantly between the late 1970s and the early 1990s.

The predictable result is public defenders' offices with very large ratios of cases to lawyers. One recent study found a jurisdiction in which some public defenders represented over four hundred felony defendants in an eight-month span, and the average representation was more than half that number. ${ }^{20}$ In another jurisdiction, some lawyers represented over one thousand misdemeanor defendants in one year; again the averages were not vastly different. ${ }^{21}$ These numbers are, of course, extreme; more typical ratios are no doubt lower (though little data exist on what more typical ratios are). Still, those familiar with the system agree that the story these numbers tell is generally true: Public defenders are terribly overburdened. ${ }^{22}$

The story is essentially the same in jurisdictions that use separately appointed defense counsel rather than public defenders. Such counsel are usually paid according to statutory fee schedules that fix hourly amounts, sometimes varying the amount for pretrial preparation, trial, and appeal. Often the hourly fees are quite low: In Alabama, defense counsel receive $\$ 20$ per hour for out-of-court time; ${ }^{23}$ in New York, the figure is $\$ 25 .{ }^{24}$ Not all the hourly rates are so stingy: Nevada offers $\$ 75$ per hour, ${ }^{25}$ and rates of $\$ 40$ per hour are not unusual. ${ }^{26}$ The real key to the statutory fee schedules, however, is not the hourly amounts but the caps on total fees. Most states have such caps, ${ }^{27}$ they range as low as $\$ 265^{28}$ and go no higher than $\$ 3500$ for

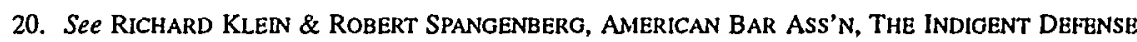
CRISIS 8 (1993).

21. See id.

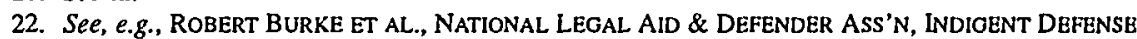
Caseloads AND Common Sense: AN UPdATE 3-5 (1992); Charles J. Ogletrce, Jr., An Essay on the New Public Defender for the 21st Century, LAW \& CONTEMP. PROBS., Winter 1995, at 81, 85-86; see also LisA J. MCINTYRe, THE PUBlic DEFENDER: The PRACTICE OF LAW IN THE SHADOWS OF REPUTE 103-04 (1987) (discussing docket pressures and limits on training of new public defenders). The current trend in the literature is to argue that, despite these resource constraints, public defenders do a surprisingly good job.

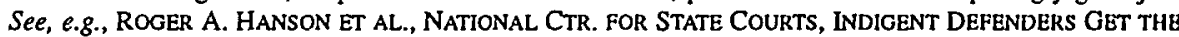
JOB DONE AND DONE WELL (1992); John B. Mitchell, Redefining the Sixth Amendment, 67 S. CAL. L. REV. 1215 (1994).

23. See ALA. CODE $\S 15-12-21(d)$ (1995).

24. See N.Y. COUNTY LAW § 722-b (McKinney 1991).

25. See NEV. REV. STAT. ANN. $§ 7.125 .1$ (Michie Supp. 1995).

26. See, e.g., S.C. CODE ANN. § 17-3-50(A) (Law Co-op. Supp. 1996); WIS. STAT. ANN. § 977.08(4m)(b) (West Supp. 1996); ALASKA ADMIN. R. 12(d)(2)(F).

27. Virtually all states that statutorily specify fees for appointed counsel have caps. Some states do not specify fees by statute, but rather provide that a judicial or executive commission will set fees. See, e.g., ARK. CODE ANN. § 16-87-209(g) (Michie Supp. 1993); MASS. GEN. LAWS ANN. ch. 211D, $\$ 12$ (West Supp. 1997); OR. REV. STAT. $\$ 151.430(5)-.430(6)$ (1995). Finally, a large number of states provide that fees are at the discretion of the trial court. See, e.g., ARL. REV. STAT. ANN. \$13-4013 (West 1989); CAL. PENAL CODE $\S 987.2$ (a) (West Supp. 1997). As there is no contrary indication in the literature on this subject, I assume that those states that do not statutorily specify fees pay counsel at rates comparable to those states that do.

28. See VA. CODE ANN. § 19-2-163 (Michie 1995). 
noncapital felonies. ${ }^{29}$ The typical range is $\$ 500$ to $\$ 1000 .^{30}$ These caps can be waived for good cause, but the governing statutes seem designed to ensure that waiver is exceptional, typically requiring a finding that the waiver was "necessary" or the circumstances "extraordinary." Thus, a typical appointed defense lawyer faces something like the following pay scale: $\$ 30$ or $\$ 40$ an hour for the first twenty to thirty hours, and zero thereafter.

This phenomenon is familiar, and it is the source of a familiar complaint. For at least the past decade, one of the standard attacks on the criminal justice system has been the attack on its poverty-especially the poverty of defense counsel, whose pay scales seem to preclude more than nominal litigation in more than a tiny number of cases. ${ }^{32}$ But for all the (justified) complaining about resources, no one has paid much attention to the way the resources relate to, and perhaps respond to, defendants' rights-to the way legislative funding decisions bear on the judge-made law that governs the criminal process, and vice versa.

In other areas the relationship is well known. When the Reagan Administration sought to deregulate various private industries, it did not devote its energies solely to pushing legislation that would overturn objectionable rules. Opponents of regulation also sought to cut funding for agencies that issued the kind of rules the opponents disliked. ${ }^{33}$ The idea behind the strategy was clear enough: Less money to an agency that makes bad policy means less bad policy. The disagreement was over substantive law, but funding strategies are valuable weapons in substantive fights.

The criminal justice system is a prime candidate for the same approach. There are a great many constitutional rules, most of which are highly contestable. The rules are produced by a cour system that acts quite independently of legislative preference, at least in this area. (Mapp v. Ohio ${ }^{\text {s4 }}$ $50(A)$.

29. See, e.g., OKLA. STAT. ANN. tit. 22. \$1355 8(G)(2) (WesI Supp 1997), S C CODE ANN $\$ 17.3$.

30. See, e.g., KY. REV. STAT. ANN. \$31.070 (Múchic 1992) (\$1000); NísS CODE ANN $\$ 99.15 .17$ (1994) (\$1000); N.H. REV. STAT. ANN. \$604-A:5 (1986) (\$500). ALASKA ADMLN R 12(d)(2)(F)(\$500)

31. See, e.g., GA. CODE ANN. § 17-12-5(b) (1990) (allowing waver in exurzordinary circumslances). KY. REV. STAT. ANN. $\$ 31.070$ (3) (Michic 1992) (stating that fees in excess of the cap are presumptively prohibited); MINN. STAT. ANN. §611.21(b) (West Supp. 1997) (allowing waver only when necessary to provide compensation for services of an unusual nature and requinng the chicf judge of the fistrict to approve any excess); N.H. REV. STAT. ANN. \$ 604-A:5 (1986) (allowing waver only in certaun leluny cases with extraordinary circumstances); TENN. CODE ANN $\$ 40-14-207(4)(2)$ (1990) (ullowing waver when necessary to provide fair compensation and requinng approval for excess from the chicf justice of the stale supreme cour).

32. See, e.g., Stephen J. Schulhofer \& David D Fnodman. Rethunkng Indigent Defense Pronotung Effective Representation Through Consumer Sovereignn and Freedom of Chouce for All Cruminal Defendants, 31 AM. CRIM. L. REV. 73, 93-94 (1993); sources cited supra noic 22

33. See Thomas O. McGarity. Regulaton. Reform in the Reagun Era. 45 Mid L RtV 253. 263 (1986). Rober L. Rabin, Federal Regulation in Historical Perspecrive, 38 STAN L REV 1189, 1318 (1986)

34. 367 U.S. 643 (1961). Mapp applied the tederal exclustonary rule, then and now the dominant remedy for Fourh Amendment violations, to the states See id at 655-57 
and Miranda v. Arizona ${ }^{35}$ were hardly examples of majoritarian lawmaking.) Perhaps more so than anywhere else in constitutional law, in criminal procedure the broad exercise of judicial power tends to be justified precisely by legislators' unwillingness to protect constitutional interests. Yet these judgemade rules are enforced through the efforts of criminal defense counsel who, in most cases, are paid by the state-the same state whose preferences the rules purport to trump. By buying less criminal defense, the state can buy less enforcement of constitutional criminal procedure. It can, to some degree, trump the trump. Of course, if it does so it necessarily also buys less of whatever else criminal defense counsel do.

\section{B. Criminal Procedure as an Incomplete Regulatory System}

What one thinks of this dynamic depends in part on the nature of the law criminal defense counsel enforce. Constitutional criminal procedure protects criminal defendants' rights. As elsewhere in constitutional law, the rights are almost all negative; defendants have the right to be free from certain kinds of government conduct. More particularly, they have the right to be free from criminal conviction except when the government follows a given set of procedures. Thus, defendants' rights are really the system's rules, rules that regulate the conduct of the various actors who take part in the process by which some criminal defendants are convicted and punished.

Broadly speaking, those rules do three things that separate the law of criminal procedure from the mostly nonconstitutional law of civil procedure. The first is obvious: Criminal procedure skews errors in defendants' favor, as by requiring proof of guilt beyond a reasonable doubt. ${ }^{36}$ The second is more subtle and often goes unnoticed, though it is extremely important as a practical matter: Constitutional criminal procedure limits trial judges' flexibility; it restricts a kind of discretionary trial management that is routine in civil cases. ${ }^{37}$ Criminal procedure's third role is more akin to tort than to conventional procedure: The law extensively regulates the conduct of various actors in the system, ranging from police officers and prosecutors to defense attorneys and court personnel. All three sorts of law depend for their enforcement on an adequate level of litigation by defendants, meaning in practice by defense counsel. Nevertheless, the system leaves the level of defense litigation (and the level of government litigation as well)

35. 384 U.S. 436 (1966). Miranda required police to warn suspects of their right to remain silent and their right to have counsel present during questioning, and held that statements obtained after these rights were read would be admissible only if the government carried a "heavy burden" of showing that these rights were waived "knowingly and intelligently." Id. at 467-75.

36. See In re Winship, 397 U.S. 358 (1970).

37. For a good discussion of the nature and sources of this phenomenon in the civil sphere, sce Judith Resnik, Managerial Judges, 96 HARV. L. REV. 376 (1982). 
constitutionally unregulated, and hence subject to legislative control.

The first of these three roles requires little discussion. Placing a heavy burden of proof on the government in criminal cases is uncontroversial, since one of the few propositions in this area about which everyone agrees is that the ratio of guilty acquittals to innocent convictions should be high. There are a few other doctrines of this sort-Gideon's requirement that indigent defendants receive counsel is a prime example ${ }^{38}$ - but not many.

The second is more complicated and deserves a brief detour. In civil cases the scope and length of discovery are to a large degree within the control of trial judges, who can give the parties as much or as little rope as the judges wish. ${ }^{39}$ So too, in civil cases judges have a great deal of authority to bar particular lines of relevant questioning or argument or particular bodies of relevant evidence on the ground that they are unduly prejudicial or simply a waste of time. ${ }^{40}$ Such decisions have some legal limits, but the limits do not matter much, if only because of the gentleness of abuse-of-discretion appellate review. ${ }^{41}$ The upshot is a great deal of negative judicial control in civil cases at the trial level, with judges able to cabin the parties' presentation of their cases. Our system of civil adjudication is adversarial; it rests on the idea of party control. But party control is bounded, and bounded significantly, by the power of trial judges.

Criminal litigation is different. A major portion of discovery is constitutionalized-the government must turn over exculpatory evidence, period. ${ }^{42}$ Trial judges have no power to truncate this requirement. The defendant's right to confront opposing witnesses means that trial court decisions to cut off a line of defense cross-examination at trial can raise substantial constitutional concerns. ${ }^{43}$ The right to compulsory process means that decisions barring particular defense witnesses also trigger constitutional alarm bells. ${ }^{44}$ Where these Sixth Amendment rights fail, the Due Process

38. See Gideon v. Wainwright, 372 U.S. 335 (1963). In Gideon ttself. 22 state attumeys general joined in an amicus brief on the defendant's side. See id. at 336 This was an carly indication of the widespread support the right to appointed counsel would enjoy, no doubi because that nght. like the beyond-areasonable-doubt standard, is so obviously protecuve of innocent defendants

39. For an excellent discussion of this point, see Stephen C Yeazell. The Misunderstood Consequences of Modem Civil Process, 1994 WIS. L. REv. 631. 649-54 Yejzell's essisy shows how this aspect of discovery practice is part of a larger shift in power from appellate courts to inal courts, a shift that began early in this century and has accelerated since.

40. See, e.g., Fed. R. Evid. 403; GRAHAM C. LILLY. AN INTRODUCTION TO tht LaW of EVIDENCE 36-37 (1978).

41. For the classic discussion (and criticism) of the abuse-of-discretuon standard, see Henry I Fnendly. Indiscretion About Discretion, 31 EMORY L.J. 747 (1982)

42. See Brady v. Maryland, 373 U.S. 83 (1963) Note that this requirement extends to cridence that the defendant has not requested. See United States v Agurs, 427 U S 97 (1976)

43. See, e.g., Olden v. Kentucky, 488 U.S. 227 (1988) (per cunium) Olden is discussed infra notes 47-51 and accompanying text.

44. For still-classic discussions, see Peter Westen, The Compulsong Process Clause. 73 Mich L Rev 71 (1974); and Peter Westen, Confrontanon and Compulson Process* A Unufied Theor of Estadence for Criminal Cases, 91 HARV. L. REv. 567 (1978). 
Clause gives defendants a potential claim whenever the trial court takes some defense evidence or argument off the table. ${ }^{45}$ These various constitutional claims do not always win. On the contrary, as with all criminal procedure claims, defendants usually lose. And even when defendants win on the merits of the claim, they can lose cases if appellate courts find errors harmless. But one should not minimize the shadow these rights cast. Harmless error review in criminal procedure is a far cry from its equivalent in civil procedure; it leaves much less room to the discretion of trial courts. ${ }^{46}$ And while constitutional challenges to trial management are not often litigated (and usually lose when they are), they are always potentially present, creating a risk of appellate litigation and reversal for trial court judgments that would go unchallenged in civil cases.

An obscure recent Supreme Court case makes the point nicely. In Olden v. Kentucky, ${ }^{47}$ a black man was charged with raping a white woman in his car late at night. After the alleged rape, the defendant drove the victim, at her request, to a friend's house. The victim's friend was a married black man. When she got out of the car, the victim immediately reported the rape to her friend, whose testimony to that effect was offered at trial some months later. ${ }^{48}$ The defense sought to show that at the time of trial the victim and her friend were sexually involved. By this time, the friend had left his wife. The theory was that since the two were lovers now, they might have been lovers at the time of the alleged rape, which would have given the victim reason to concoct the rape story as a means of explaining why she was driving around with the defendant late at night. The trial court barred the whole line of questioning, saying that the inferences were too tenuous, the issue was too much of a distraction, and there was obvious potential prejudice to the government. ${ }^{49}$ (The defense seemed to be trying to suggest to the jury that the victim liked

45. See, e.g., Skipper v. South Carolina, 476 U.S. 1 (1986) (holding that, in the sentencing phase of a capital murder trial, a defendant must be allowed to introduce evidence of good behavior in prison while awaiting trial to rebut the prosecutor's contention that the defendant would pose disciplinary problems if sentenced to prison).

46. In civil cases, error is harmless unless it "appears . . inconsistent with substantial justice" and "affect[s] the substantial rights of the parties." FED. R. CIV. P. 61; see 11 CHARLeS ALAN WRIOHT \& ARTHUR R. MILlER, FEDERAL PRACTICE AND PROCEDURE $\S \S 2881-88$ (1995). This standard holds as well for nonconstitutional errors in criminal cases, see Kotteakos v. United States, 328 U.S. 750 (1946), and for constitutional errors found on habeas corpus, see Brecht v. Abrahamson, 507 U.S. 619 (1993). For constitutional errors on direct appeal, however, the standard is harmless beyond a reasonable doubt, a much tougher threshold. See Chapman v. California, 386 U.S. 18 (1967). This is worth emphasizing because the criminal procedure literature on harmless error tends to focus on the cases where errors are found harmless, thereby creating the impression that appellate review of criminal procedure claims is lax. See, e.g., Stephen H. Goldberg, Harmless Error: Constitutional Sneak Thief, 71 J. CRIM. L. \& CRIMINoloor 421 (1980); Stephen A. Saltzburg, The Harm of Harmless Error, 59 VA. L. Rev. 988 (1973); Tom Stacy \& Kim Dayton, Rethinking Harmless Constitutional Error, 88 CoLUM. L. REV. 79 (1988). By the standards the legal system employs elsewhere, this impression is false.

47. 488 U.S. 227 (1988) (per curiam).

48. See id. at 228-29 (per curiam).

49. See id. at 229-30 (per curiam). 
sex with black men, and so probably consented to sex with the defendant.) ${ }^{\text {so }}$ The Supreme Court reversed in a brief per curiam opinion with only one dissent, and that not on the merits. ${ }^{51}$ Not only did the trial cour's decision violate Olden's right to confront the witnesses against him; the decision clearly violated Olden's rights. The Cour treated the case as easy. Olden's claim was, to use the current vernacular, a "slam dunk."

Cases like Olden send a powerful signal. Judges may and do shape criminal trials, but they do so at much greater risk of reversal than when they exercise the same kind of control over civil litigation. This risk is, of course, one-sided, given both the nature of the constitutional protections and the longstanding rule barring appeal of acquittals. Yet in a world in which the defense has more leeway, it seems plausible to suppose the government will be given a fair amount of leeway too. Trial judges are likely to be at least roughly reciprocal in terms of their approach to trial management. So the effect of this part of constitutional criminal procedure may be to create a presumptive right to go where the litigators want, with judicial limits imposed only for very good reason. That heightened degree of party control is then enforced by a system of Olden-style, ad hoc appellate policing of discretionary trial coun judgments.

The criminal procedure literature treats that system as relatively unimportant. The partial constitutionalization of trial management has received little comment, drowned out by discussions of other aspects of the criminal procedure revolution of the 1960 s and 1970s. This inattention is a serious mistake. Consider the massive, unwieldy nature of O.J. Simpson's trial. That fiasco had many causes, not least of which was the trial judge's lax management of the case. It has become commonplace to observe that a different judge might have forced the parties to present their cases much more tightly and much more quickly. ${ }^{52}$ Yet the chances of a streamlined Simpson trial were always smaller than this standard line suggests. More aggressive

50. That was the view taken by the Kentucky Coun of Appeals, which emphusiced the harm to the victim's credibility that would have been caused even by a showing that the vieum was involved with a black man at the time of the trial. See id. at 231 (per curtam) (quoting the unreponed opinion of the Kentucky Court of Appeals).

51. Justice Marshall's lone dissent said nothing about the issue or facts in Olden, but rested sulely on his objection to summary dispositions. See id. at 233-34 (Marshall. J . dissenung)

52. See, e.g., JefFrey TOOBIN, The RUN OF His LIFE: THE Plople V OJ SIMPSON 347 (1996) Toobin writes:

Ito floundered. Courroom discipline fluctuated according to the judge's press clippings When, as happened periodically, a big story in the Los Angeles Times or on one of the networks chided him for letting the case drag on. the judge would snap to attentuon for a day or two, refusing to hold sidebars and generally pushing things along $\mathrm{H}_{\text {is }}$ resolve would then fade untul the next critical story. After Newsweek put Ito's picture on the cover under the headline WHAT A MESS, the judge lashed back at the press by permanenuly evicting two reponets trom the courroom, ostensibly for talking. . . When The New York Times published a hostule colturial entitled "Bankers' Hours for the O.J. Case?" Ito lengthened the coun day Fundamentally. though, nothing much changed.

Id. 
management of the trial would have substantially raised the odds that a conviction (had one been obtained) would have been reversed, and trial judges dislike reversals. ${ }^{53}$ The threat of reversal was much weaker before constitutional law began to regulate trial management, which may be why one finds no analogues to the Simpson trial before the late 1960s. The past hundred years have seen many "trials of the century"-Lizzie Borden, Sacco and Vanzetti, the Lindbergh kidnapping case, Lucky Luciano, and the Rosenbergs are the classic examples from roughly the first half of that period. Yet in all the cases just mentioned the defendants' trials lasted between two and six weeks. ${ }^{54}$ Trials in more contemporary cases of this sort-Charles Manson, Patty Hearst, John Hinckley, Jr., Klaus von Bulow, the Menendez brothers, and, of course, Simpson-tend to be considerably longer. The length of those trials ranged from six weeks to more than eight months, with an average length of four months..$^{55}$ (Not coincidentally, defendants also win these cases more often than they used to. $)^{36}$ In short, cases like Simpson's may not be inevitable today, but they are at least understandable. Forty years ago, they weren't. The ad hoc constitutional regulation of trial management helps to explain why.

The third key aspect of the law of constitutional criminal procedure is captured by famous Warren-era cases such as Mapp ${ }^{57}$ and Miranda. ${ }^{58}$ These cases, and the many others like them, are more explicitly regulatory: They tell the police, prosecutors, the court system, and even defense lawyers what not

53. That trial judges dislike reversals is universally assumed though almost never examined. For a rare (brief) examination, see Evan H. Caminker, Precedent and Prediction: The Fonward-Looking Aspects of Inferior Court Decisionmaking, 73 TEx. L. REV. 1, 77-78 (1994). For a more extended discussion that rules out several possible explanations for the judicial taste for affirmance, see Richard S. Higgins \& Paul H. Rubin, Judicial Discretion, 9 J. LEGAL STUD. 129 (1980).

54. Lizzie Borden's trial was the shortest, lasting a mere two weeks. See EDMUND PEARsON, TRIAL OF LIZZIE BORDEN 95 (1937). The Rosenbergs' trial lasted three weeks. See WALTER SCHNEIR \& MIRIAM SCHNEIR, INVITATION TO AN INQUEST 119, 167 (1965). Luciano's trial, which made its prosecutor a national political figure, lasted three-and-a-half weeks. See MARY M. STOLBERO, FIOHTINo OROANIzED Crime: Politics, Justice, AND the Legacy of Thomas E. Dewey 134, 152 (1995). The trial of Sacco and Vanzetti lasted six weeks, see LouIs JOUGHN \& EDMUND M. MORGAN, THE LEGACY OF SACCO AND VANZETTI 10-11 (1948), as did Bruno Hauptmann's trial, see GEORGE WALLER, KIDNAP: THE STORY OF THE LiNDBERGH CASE 254, 467 (1961).

55. Hearst's and Hinckley's trials lasted seven weeks each. See THE TRIAL OF PATTY HEARST 1, 602 (1976) (reprinting the trial proceedings); LINCOLN CAPLAN, THE INSANITY DEFENSE AND THE TRIAL OF JOHN W. HINCKLEY, JR. 89 (1984). Von Bulow's first trial lasted more than two months; his second trial went six weeks. See ALAN M. DERSHOWITZ, REVERSAL OF FORTUNE: INSIDE THE VON BULOW CASB 42 , 182, 229 (1986). The Menendez brothers' first trial lasted five months. See HAZEL. THORNTON, HUNO JURY: THE DiARY OF A MENENDEZ JUROR at xix (1995). The trial of Manson and his "family" lasted seven months. See GEORGE BISHOP, WITNESS TO EVIL 416 (1971). Simpson's lasted more than eight months. See TOOBIN, supra note 52 , at $242,429$.

56. Of the more recent cases mentioned in the text, John Hinckley, Jr., Klaus von Bulow, and O.J. Simpson won, while the Menendez brothers gained a mistrial before being retried and convicted; Charles Manson and Patricia Hearst both lost. Of the earlier defendants, only Lizzie Borden was acquitted; all the others-Sacco and Vanzetti, Bruno Hauptmann (the defendant in the Lindbergh kidnap-murder prosecution), Lucky Luciano, and the Rosenbergs-were convicted.

57. Mapp v. Ohio, 367 U.S. 643 (1961).

58. Miranda v. Arizona, 384 U.S. 436 (1966). 
to do and what will happen if they do it. This par of criminal procedure has no real analogue in civil procedure doctrine. It is more like a species of ton law, defining liability rules for a given set of actors in the criminal justice system but using the threat of reversal in criminal litigation rather than damages or injunctive relief to enforce those standards.

The massive bodies of law governing police investigation are the largest and best example. When the police frisk a suspect on the street, make an arrest, search or impound a car, enter a dwelling or office, or ask a suspect questions, Fourth and Fifth Amendment rules govern their conduct. Violation of those rules generally leads to suppression of evidence discovered during the course of the violation, and often to suppression of the fruits of that discovery as well, ${ }^{59}$ so the rules themselves are developed and enforced in criminal proceedings.

The most striking thing about this law is its sheer size. Fourth and Fifth Amendment law (along with a few scattered doctrines based on the Sixth and Fourteenth Amendments) do not just set outer boundaries for police conduct, with the day-to-day judgments governed by state or local law or custom. With respect to police misconduct, constitutional criminal procedure occuptes the field. Professor LaFave's treatise on the law of search and seizure spans five volumes, ${ }^{60}$ and those five volumes do not touch Miranda's constitutional code of police questioning, with its elaborate doctrines defining when suspects are in custody, ${ }^{61}$ what counts as police interrogation, ${ }^{62}$ and (especially) the

59. Evidence discovered as a result of a Fourh Amendment violation is ordinunly indemissible Sec

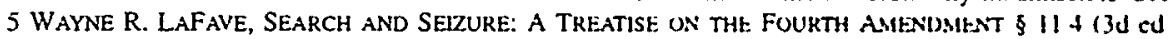
1996) (discussing the fruit-of-the-poisonous-tree doctnne) There is an exception for sume tllegal seafihes conducted in good faith, but as of now that exception apphes only in warrant cuses See United States $v$ Leon, 468 U.S. 897 (1984). With respect to police interrogation. Miranda establishes its uwn exclusionary rule. See Miranda, 384 U.S. at 444. But untike Fourh Amendment violations, Mftranda violutuons do nut ordinarily require suppression of fruits of the volation; suppression is hmiled to the illegully ubtuned statements themselves. See Oregon v. Elstad, 470 U S 298. 304-09 (1985)

60. See LAFAVE, supra note 59.

61. The major Supreme Court cases give some flavor of the doctrine's cumplexuly See Berkemer v McCarty, 468 U.S. 420 (1984) (holding that traffic stops are not necessanly custodisl, though arrests are). Minnesota v. Murphy, 465 U.S. 420 (1984) (holdıng that questioning by a probstion oflicer in a prubstion office during a regular appointment is not custodial). Calıfornı $\vee$ Behcler. 463 U S 1121 (1953) (per curiam) (holding that the defendant's presence at a police station was voluntury even though an officer accompanied him there); Oregon v. Mathiason, 429 U S 492 (1977) (per cunam) (holdıng that questioning in a police station is not custodial if the suspect's presence w'ds voluntary) The boltom line is that custudy tums on all the circumstances; is usually, but not always, present when the suspect is in a police station. is usually absent at brief street stops but (agan) not always, and does not necessanly track any uther legal categories such as arrests or stops.

62. "Interrogation" is present when officers have engaged in "ether express questioning or its functional equivalent." Rhode Island v. Innis, 446 U S 291. 300-01 (1980) The "functuonsl equivalent" of direct questioning, in turn, consists of "words or actions on the pan of police officets that they should have known were reasonably likely to elicil an incrimınaung response " Id tt 302 The "reasonsbly likely" test, however, is to be applied with an eye not merely to the reasonable foresecability and litelihood of incriminating responses, but with an emphasis on the coerciveness (or lack thereof) of the relevant police tactic. See Illinois v. Perkins, 496 U.S. 292 (1990) (holding that an undertover poltec ofticer had nut triggered Miranda safeguards when he elicited a voluntary confession trom an inmule). Aricons v Mauro. 481 U.S. 520 (1987) (holding that a police officer's tape recording of a conversation beiween the suspect 
conditions that must be met for a valid waiver of the suspect's rights. ${ }^{63}$ All these doctrines amount to a vast constitutional tort law for the police.

The tendency is to think that constitutional regulation of this sort begins and ends with the police. In fact, criminal procedure regulates much more than police investigation. A wide variety of constitutional doctrines aim to channel the conduct of some set of actors in the system in order to get them to behave in a way that will make the system as a whole function better.

The examples are endless. Consider the large bodies of law that govern grand jury ${ }^{64}$ and petit jury selection ${ }^{65}$ (and that require automatic reversal of criminal convictions in case of violation $\left.{ }^{66}\right)$. Selection practices that were close to universal a couple of decades ago, such as the use of "key man"

and his wife did not constitute interrogation for purposes of Miranda). None of this answers a question that has cropped up repeatedly in lower courts: Does a police question or comment given in response to a question by the suspect count as interrogation? For analyses of that question, see, for example, United States v. Taylor, 985 F.2d 3 (1st Cir. 1993); and People v. Clark, 857 P.2d 1099 (Cal. 1993) (in bank).

63. Miranda waiver doctrine breaks down into several distinct bodies of law. First are the cases that define whether the warnings given to the suspect were adequate. See, e.g., Duckworth v. Eagan, 492 U.S. 195 (1989). Then there are the many cases that define whether, once the suspect received the requisitc warnings and agreed to talk, the decision to talk was voluntary, knowing, and intelligent. See. e.g., Moran v. Burbine, 475 U.S. 412 (1986). Next are the cases that determine whether the suspect invoked either his right to counsel or his right to remain silent. See, e.g., Davis v. United States, 512 U.S. 452 (1994). These lead to the several lines of cases that define the consequences of such invocations. See, e.g., Minnick v. Mississippi, 498 U.S. 146 (1990) (barring police-initiated post-invocation questioning even where the suspect was allowed to consult with his attorney); Arizona v. Roberson, 486 U.S. 675 (1988) (barring postinvocation questioning about different crimes); Edwards v. Arizona, 451 U.S. 477 (1981) (barring most questioning after an invocation of the right to counsel); Michigan v. Mosley, 423 U.S. 96 (1975) (permitting questioning after an invocation of the right to remain silent, where the questioning was conducted by different officers and two hours had elapsed). Finally, there are cases in which the suspect invoked his rights but reinitiated contact with the police, thereby re-triggering the more lenient Mirandawaiver regime. See, e.g., Oregon v. Bradshaw, 462 U.S. 1039 (1983). And this is only a capsule summary.

64. Constitutional law regulates grand jury selection in three distinct ways. First, the Equal Protection Clause forbids discriminatory selection practices. See Castaneda v. Partida, 430 U.S. 482 (1977). Discrimination must be intentional, of course, but intent seems to mean something different (and to be less difficult to prove) in grand jury cases than in other kinds of equal protection cases. See Danicl R. Ortiz, The Myth of Intent in Equal Protection, 41 STAN. L. Rev. 1105, 1119-26 (1989). Second, the Equal Protection Clause forbids intentional discrimination in the selection of the grand jury foreman. See WAYNB R. LaFave \& Jerold H. IsRael, Criminal Procedure $\S 15.3(\mathrm{~b})$, at $624-26$ (1985). Third, the Fifth Amendment requires that grand juries be selected from a fair cross-section of the community. See idl. $\S$ 15.4(d), at 702-03.

65. Petit jury selection is governed both by the Sixth Amendment's fair cross-section requirement, see Duren v. Missouri, 439 U.S. 357 (1979), and by the Equal Protection Clause, see Batson v. Kentucky, 476 U.S. 79 (1986). Fair cross-section violations apply only to the pool from which the jury is drawn, not to the jury itself. See Lockhart v. McCree, 476 U.S. 162, 173-74 (1986). Equal protection violations include intentional race- or sex-based use of peremptory challenges. See J.E.B. v. Alabama ex rel. T.B., 511 U.S. 127, 130-31 (1994); Batson, 476 U.S. at 89. The law regulating use of peremptory challenges has, of course, exploded in the decade since Batson was decided.

66. The Supreme Court has explicitly held that grand jury discrimination is subject to an automatic reversal rule. See Vasquez v. Hillery, 474 U.S. 254, 260-64 (1986). Elsewhere, automatic reversal seems to be assumed without discussion. See, e.g., Batson, 476 U.S. 79 (1986) (reversing a defendant's conviction based on an equal protection violation in the selection of a petit jury, without discussing prejudice); Duren, 439 U.S. 357 (1979) (reversing a defendant's conviction without discussing prejudice to the defendant from a violation of the fair cross-section requirement in the selection of the jury venire). For an interesting discussion of what the automatic reversal rule says about the substance of the law governing jury selection, see Eric L. Muller, Solving the Batson Paradox: Harmless Error, Jury Representation, and the Sixth Amendment, 106 YALE L.J. 93 (1996). 
systems and free play for peremptory challenges, are now either flatly unconstitutional or pose a serious risk of unconstitutionality in particular cases. ${ }^{67}$ Or, consider the less massive but also less penetrable double jeopardy doctrines governing the granting and effect of mistrials ${ }^{\text {as }}$ and the effect of reversing convictions on appeal. ${ }^{69}$ Or the law of ineffective assistance of counsel ${ }^{70}$ including conflict-of-interest doctrine, ${ }^{71}$ which plays the role that legal malpractice and legal ethics together play in civil litigation. All these bodies of law are substantial and detailed, each is the prime source of the regulated actors' legal obligation within its sphere, and all are enforced through ordinary criminal litigation. Along with the law of police investigation, these areas have one more thing in common: All have seen vast doctrinal expansion over the past generation.

Many of these doctrines are accuracy-enhancing in a broad sense. Perhaps, all else being equal (a huge qualifier), a system that follows current Sixth and Fourteenth Amendment rules on juries will lead to fewer wrongful convictions than a system that ignores those rules. Law of this sor is thus different from most of criminal procedure's extensive regulation of the police, in which accuracy plays a very small role. But this sort of law should not be confused with doctrines that seek simply to tilt errors in the defendant's favor, like the beyond-a-reasonable-doubt standard of proof. The point of criminal procedure's regulatory doctrines is sometimes accuracy, but not accuracy in any particular case-rather, the point is to get prosecutors, court personnel, and defense attorneys to behave properly.

So the law of criminal procedure establishes a detailed regulatory system. That law covers a wide range of issues that elsewhere are not part of the law of procedure at all-consider search and seizure, or ineffective assistance of counsel. With respect to more paradigmatically procedural issues, criminal procedure leaves less room than does civil procedure for discretionary control by the court system on the ground-recall Olden. ${ }^{22}$ There is an enormous

67. On the constitutional problems with "key man" systems, see Casfaneda, 430 U S at 497 , where the Court noted that although such systems are facially conslituuonal, they are "highly subjectuve" and therefore "susceptible of abuse." Peremptory challenges are now unconstututional if they are motuvaled by race or gender. See J.E.B., 511 U.S. at 130-31; Batson, 476 U.S. at 89

68. Reprosecution following a mistrial is permitied only if the misinal was manifesily necessary See Illinois v. Somerville, 410 U.S. $458,461-65$ (1973). What constututes manifest necessity is impossible to explain concisely. For the leading Supreme Court cases other than Somenille, see Oregon v Kenntedy. 456 U.S. 667 (1982); Arizona v. Wasitungton, 434 U.S. 497 (1978): United States v Jorm. 400 U S 470 (1971). and Downum v. United States, 372 U.S. 734 (1963).

69. Whether the defendant may be retned following reversal of a conviction depends on the reason for the reversal. Compare Lockhan v. Nelson, 488 U.S. 33 (1988) (permutung retnal when reversal was based on the improper admission of a prior criminal conviction), wilk Burks v Uniled Ststes. 437 U S 1 (1978) (barring retrial when reversal was based on insufficient evidence) If reversal is based on the wetg/t of the evidence rather than its insufficrency, retrial may be allowed See Tibbs * Flonds, 457 U S 31 (1982).

70. For the basic test, see Strickland t: Washington. 466 U S 668. 687.96 (1984)

71. See Cuyler v. Sullivan, 446 U.S. 335 (1980).

72. Olden v. Kentucky, 488 U.S. 227 (1988) (per curtam), see supra text accompanying nutes $\$ 7.51$ 
amount of regulation, and appellate courts are the dominant regulators.

This vast body of law depends for its enforcement on criminal defense counsel, the private attorneys general of the Fourth, Fifth, and Sixth Amendments. ${ }^{73}$ One might suppose, therefore, that constitutional law would contain a well-developed set of doctrines ensuring that defense counsel actually play the role for which the system casts them. Such doctrines do not exist. Ineffective assistance law is important and claims arising under that law are frequently raised, but the doctrine does very little about the failure adequately to enforce constitutional rules. Defendants tend to win ineffective assistance claims only when their lawyers had a conflict of interest or made some discrete error of great magnitude ${ }^{74}$ The failure to raise claims that constitutional law might otherwise make available (and, even more so, the failure to investigate such claims) is rarely the ground for a finding of attorney ineffectiveness. ${ }^{75}$ And, of course, most legal claims in most cases are probable losers, so it is easy for the government to argue that even a given winning claim that counsel failed to make did not look like a winner ex ante. Given the standard used for a finding of attorney ineffectiveness-basically, gross negligence-that argument tends to be quite successful.

To put it another way, ineffective assistance doctrine tolerates a very low activity level by defense attorneys. The law operates from the premise that effective representation can be minimal-as in many cases it can. (Think about the many plea-bargained cases that are resolved based on a few minutes' meeting between defense counsel and her client and a similarly brief meeting between defense counsel and the prosecutor. $)^{76}$ Once that proposition is

73. See Daniel J. Meltzer, Deterring Constitutional Violations by Law Enforcement Officials: Plaintiffs and Defendants as Private Attomeys General, 88 CoLUM. L. REv. 247 (1988).

74. Proving this statement is impossible; I can only invite the reader to test this characterization against the reported cases, which are far too many to cite. The pattern in question is the natural consequence of two features of ineffective assistance doctrine. The first is Strickland's emphasis on avoiding hindsight in assessing defense attomey performance. See Strickland, 466 U.S. at 687-91. Ironically, this stance leads to a good deal of hindsight, but only in one direction: After-the-fact rationalizations of defense attomey choices carry weight, while after-the-fact assessments of the consequences of those choices do not. The upshot is that only the kind of choice that is unjustifiable on its face can be the basis for a finding of attorney ineffectiveness. The second key feature of the doctrine is the absence of a required showing of prejudice to establish conflicts of interest (as opposed to other sorts of ineffective assistance, where prejudice must be shown). See Cuyler, 446 U.S. at 349-50. The test laid out in Cuyler allows for reversal based on a conflict of interest whenever the conflict adversely affected the representation, not merely when the effect was unreasonable or seriously harmful. See id. at 348-50. Thus ineffective assistance doctrine regulates counsel's loyalty a good deal more stringently than it regulates counsel's performance.

75. The exceptions to this general rule are revealing. For example, in Kimmelman v. Morrison, 477 U.S. 365 (1986), counsel for a rape defendant failed to move in a timely fashion to suppress the bedshect and associated lab tests that proved his client had indeed had sex with the victim. The sheet was obtained in a warrantless search of the defendant's apartment. See id. at 368-70. With it, the government could convict Morrison with ease; without it, there was no case. Given the circumstances, it is hard to imagine a more serious error than failing to move to suppress. Although the Supreme Coun found that the defendant in Kimmelman had received constitutionally deficient assistance of counsel, less extreme errors of this sort tend not to generate a finding of attorney ineffectiveness.

76. On the frequency of such cases, see, for example, Milton Heumann, Plea Baroainino 35 (1978); and Stephen J. Schulhofer, Effective Assistance on the Assembly Line, 14 N.Y.U. REv. L. \& Soc. 
granted, it becomes difficult to separate low-activity but good representation from laziness or incompetence. Current Sixth Amendment doctrine responds by basing findings of ineffective assistance mostly on identifiable gross errors rather than on inactivity.

And nothing in the law of criminal procedure regulates how much states must spend on lawyers for defendants. This too is a consequence of ineffective assistance doctrine. In order to make out an ineffective-assistance-of-counsel claim, a defendant must show, first, that his lawyer failed to provide constitutionally adequate assistance in his case and, second, that this failure may well have caused the defendant to lose his case. ${ }^{77}$ This test rules out claims based on inadequate resources. If defense counsel did indeed fail to provide constitutionally adequate assistance, the state's pay scale is irrelevant - the defendant wins no matter how well or poorly counsel was paid. If, on the other hand, defense counsel met the constitutional performance standard, the state's pay scale is again irrelevant-the defendant loses regardless of attorney pay because he got what the Sixth Amendment guarantees him: constitutionally adequate representation. This doctrinal box explains why very few cases even address the question whether states' compensation of appointed counsel can give rise to a constitutional clam. ${ }^{78}$ Existing law simply leaves no room for the claim.

Criminal procedure's regulatory system is thus incomplete. It covers the police in great detail, as it covers some aspects of prosecutors' and trial judges' conduct in great detail. It also seriously' regulates some aspects of defense counsel behavior; in contrast to the lenity of most ineffectuve assistance doctrine, the law governing conflicts of interest has substantal bite. $^{79}$ But the law leaves the level of defense litigation, on which all other constitutional regulation in this area depends, basically unregulated. Decisions not to contest plausibly contestable cases, along with decisions not to raise plausible legal claims, are close to unchallengeable. It goes without saying that the same has long been true for police and prosecutors: Decisions not to arrest, not to charge, or to press some charges rather than others are traditionally unregulated. ${ }^{80}$

CHANGE 137, 144 (1986).

77. See Strickland, 466 U.S. at 687-96.

78. For notable exceptions, see Stase : Smuh, 681 P2d 1374 (Ant 1984). and State s Peart, 621 So. 2d 780 (La. 1993). See also Kennedy v Carlson, 544 N W 2d I (Minn 1996) (holding that a public defender lacked standing to raise a Sixth Amendment challenge to a funding statule whale lesving open the possibility that such a challenge might be valud) A few courts have bypassed inelfectuve assistance doctrine, holding that underpaid appointed counsel are the victums of an uncompensaled taking of property See Arnold v. Kemp, 813 S.W.2d 770 (Ark. 1991). Stale ex rel Sicphen v Smith. 747 P2d 816 (Kan 1987); State v. Lynch, 796 P.2d 1150 (Okla. 1990)

79. See supra note 74; see also Wheat v. Unted States, 486 U S 153 (1988) (holding that a tnal court may disqualify counsel for a conflict of interest agannst the defendant's wishes)

80. The leading case is Inmates of Atrica Correcnonal Facilin , Rockefeller. $477 \mathrm{~F} 2 \mathrm{~d} 375$ (2d Cir 1973). The tradition of unreviewable arrest and charging discretuon is considerably strengthened by DeShaney v. Winnebago Count, Deparment of Social Senices. 489 U S 189 (1989), which shurply limis 
To put the point differently, constitutional criminal procedure defines what the criminal process looks like, but is agnostic about how much of that process the system should have-for that is what prosecutors and defense counsel determine, and that is the aspect of their behavior that the law leaves most to their discretion. How many cases are prosecuted, how many of those are contested, and how aggressive are the contests - these issues are left to the lawyers, subject to essentially no legal regulation.

One might fairly ask, so what? Common law regulation always has this characteristic. Products liability law alters some manufacturing processes, but says nothing about how many products are to be manufactured. Indeed, most legal regulation seeks to limit how certain things are done without limiting how much of them regulated actors do. The usual and familiar result is that we get somewhat less of the regulated activity (because regulation makes it more costly) but what we get is of better quality (assuming the regulation is sensible). If that were true in this setting, constitutional criminal procedure would simply mean fewer but fairer arrests, prosecutions, and convictions. Were that the whole story, it would hardly be worth telling.

But the relationship is more complicated than that, and much more problematic. Decisions about resources have important feedback effects on what the system looks like. And what the system looks like-the size and scope of constitutional criminal procedure-may in turn shape decisions about resources. To these issues I now turn.

\section{How CRiminal Litigation Is Rationed (ANd How CRiminal PRocedure Changes IT)}

Lawyers always ration legal claims and arguments; that is an important part of their job. Particular claims cost particular amounts to raise, and each claim has its own ex ante probability of success. If the market functions as it should, lawyers raise claims when their ex ante value, measured by their likelihood of success times the likely payout and subtracting the cost of litigating the issue, is positive. This process should serve to screen out foolish arguments while encouraging substantial ones.

Criminal litigation too is rationed, and as elsewhere, the rationing is done by lawyers. But the rationing is importantly different, for both the prosecution and the defense. On the government's side, prosecutors are bureaucrats; like other bureaucrats, their activity level is largely governed by their budgets. Rationing in this setting is akin to queuing, albeit in a system where the prosecutor defines one's place in line. On the defense side, a market mechanism sometimes functions, but the state sets the price through its appropriations for public defenders' offices or its pay scales for appointed 
counsel. These prices are vastly lower than the value of the nonmonetary sanctions to which defendants are subject. (Who would refuse to pay more than, say, a thousand dollars to avoid a long prison term, assuming he had more than a thousand dollars to pay?) The consequence is a strong incentive to litigate up to the state-set ceiling, but no farther.

Both kinds of rationing shape the effect of legal rules. Because of the path of American crime rates and because of the way prosecutors and defense attorneys are paid, the constitutionalized expansion of the law of crimnal procedure has probably done more to alter the distribution of crimnal litigation-and hence the distribution of criminal punishment-than its level. Prosecutors' likely response to more procedural rules is to charge different cases than they otherwise would, and defense counsel's likely response is to make different claims. Instead of less-but-better criminal litigation, criminal procedure may make for equally frequent litigation that is different and, in some ways, worse.

\section{A. The Prosecution}

\section{Crime Rates and the Level of Prosecution}

Like other government agencies, prosecutors' offices operate under a budget constraint. They also operate under a political constrant: Any prosecutor's office where everyone works half time while murder cases go uncharged will soon see a rise in unemployment. The relationship between those constraints-roughly, the ratio of serious crimes to prosecutors-determines whether prosecutors are working at anywhere near capacity. And whether prosecutors are working at capacity, in curn, determines the effect of legal doctrines that give some criminal defendants litigation opportunities.

Suppose, for example, that the ratio of crimes to prosecutors is moderately low; that is, suppose prosecutors have enough time, but only enough time, to handle all the cases that they both might plausibly win and would want to win. ${ }^{81}$ In that event, pro-defense changes in the law will lead to less prosecution. Some cases that were previously winners will become losers, and some cases that were previously cheap to prosecute will become expensive. Since prosecutors were using all their time and exhausting their dockets, those cases will no longer be worth prosecuting. The picture is of a prosecutor with five "winners" on his desk and just enough time to go forward with all five. A change in the law that makes one of these five cases unattractive will mean

81. This means only that they will spend enough tume to win Keep in mind that prosecuturs have no incentive to maximize the amount of tume they will spend on work 
filing charges in four cases rather than five-or perhaps litigating all five, but losing one.

Now suppose the ratio of crimes to prosecutors is much higher; that is, prosecutors have more strong cases than they have time to pursue those cases. The same legal change will cost the government little, and the cost will tend to be hidden. Instead of five winning cases on his desk, the prosecutor now has ten, with just enough time to go after seven ${ }^{82} \mathrm{~A}$ legal development that ruined one of the ten cases for the government would simply mean that the prosecutor now had to choose seven of nine. There would be some change in the distribution of cases prosecuted-some movement on the prosecutor's preference curve away from the kinds of cases in which the particular legal claim would be most likely to arise. But even that change might be hard to detect. And overall prosecution and conviction rates might change only slightly, if at all.

Indeed, the effects of the crime-to-time ratio-the relationship between the government's litigation opportunities and its litigation resources-almost certainly dwarf the effects of variations in legal doctrine on both the number of charges filed and conviction rates. If the crime-to-time ratio is bad enough, changes in the law will have little or no effect on the size of criminal dockets. Prosecutors will be able to fill their available time by taking only easy guilty pleas (making for very high conviction rates). Note how closely some urban jurisdictions, where this ratio is at its worst, approach this state of affairs: The percentage of felony convictions obtained by plea has exceeded $97 \%$ in some places, while the nationwide rate is closer to $90 \% .^{83}$

This point is key to understanding the path the law of criminal procedure has followed over the past thirty-five years. American rates of core serious crime-major theft offenses plus violent crimes-were historically low in the 1950s and early 1960s, but they rose steeply beginning in about 1962. In 1961, before this steep rise, the FBI recorded slightly under 2.1 million index crimes; in 1971 the number was just under six million. ${ }^{84}$ The increase continued, but more slowly; index crimes rose an additional $69 \%$ between 1971 and $1990 .{ }^{85}$

82. I assume that political constraints on prosecutors force them to increase their level of elfort somewhat as caseloads rise; hence the change from five cases exhausting the prosecutor's available time in the first scenario to seven cases in the second. The point, once again, is that "available" time is likely to expand somewhat, though it still functions as a constraint.

83. Compare Bureau of Justice Statistics, U.S. Dep'T of Justice, Sourcebook of CRIMINal. JustiCE STATISTICS - 1995, at 498 tbl.5.47 (Kathleen Maguire \& Ann L. Pastore eds., 1996) (hereinafter 1995 SOURCEBOOK] (showing a nationwide rate of guilty pleas as a percentage of felony convictions of 92\% in 1992), with BARBARA BOLAND ET AL., U.S. DEP'T OF JUSTICE, THE PROSECUTION OF FELONY ARRESTS, 1987, at 91 (1990) (showing a rate of 96\% in Denver), id. at 92 (99\% in Littleton, Colorado). id. at 93 (96\% in Los Angeles), id. at 94 (97\% in Manhattan, New York City), and id. at 97 (97\% in San Diego).

84. See 1972 UNIFORM CRIME REPORTS, supra note 11 , at 61 tbl.2.

85. In the 1970 s the method used for calculating the number of index crimes was changed. See FBI, UNIFORM CRIME REPORTS FOR THE UNITED STATES-1973, at 1 (1974). The recalculated 1971 figure was 8.6 million. See 1980 UNIFORM CRIME REPORTS, supra note 10, at 41 tbl.2. By 1990 the number had risen 
The cumulative increase is staggering. In less than three decades, index crimes nearly quintupled, while the population grew by only one-third. ${ }^{\text {so }}$

Those numbers actually understate the increase in crime, for they do not include drug offenses. The combination of a substantial increase in some types of drug crime and a growing public preference for "get-tough" drug policies led to a large increase in the number of drug prosecutions, especially after the mid-1970s. Drug arrests more than quintupled between 1968 and 1988, and by 1990 , drug cases accounted for one-third of state felony convictions. ${ }^{87}$

The data on numbers of criminal prosecutors is very sketchy, but that number has apparently grown a good deal more slowly than the number of serious crimes, especially if one counts drug offenses. The only available study that provides nationwide estimates concludes that the number of state and local assistant prosecutors grew from approximately 17,000 in 1974 to approximately 20,000 in $1990^{88}$ - not nearly enough to keep up with the contemporaneous increase in index crimes, much less the increase in drug crime. Other data suggest a larger increase, but still not large enough. Total personnel in local prosecutors' and city attorney's' offices grew from 25,954 to 58,408 between 1971 and $1990 .^{89}$ Good data on personnel increases in the 1960 s do not exist, but it seems likely that much of the growth after 1970 was an effort to catch up with the $187 \%$ increase in index crimes during the $1960 \mathrm{~s}^{90}$-an increase that surely took legislative budget committees, along with everyone else, by surprise. Moreover, the personnel increase probably overstates the growth in the number of prosecutors, since the personnel figures include city attorneys' offices (the number of employees in prosecutors' offices alone apparently does not exist for most of the relevant time period). Those offices experienced a major increase in their workload beginning in the late 1970s. In 1976, Congress passed legislation granting attomeys' fees to successful civil rights plaintiffs," and in 1978, the Supreme Cour held that municipal governments could be sued directly under $\$ 1983 .{ }^{42}$ Some portion of the personnel increase is probably a response to those events. Given these factors, the index-crime-to-prosecutor ratio is almost cerainly higher today, probably by a wide margin, than it was thirty-five years ago. And, again, that

to 14.5 million. See 1991 UNIFORM CRME REPORTS, supra note 10. at 5

86. In 1961 the American population was close to 184 milhon, by 1990 it had groun to nearly 250 million. See 1996 STATISTICAL ABSTRACT, supra note 8 , at 8

87. See supra notes 12-13 and accompanytng lext.

88. See Bureau of Justice Statistics, US. Dep't of Justict. Prosecutors iN State. CouRTS-1990, at 1-2 (1992).

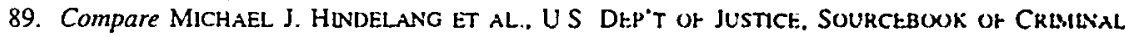
JUSTICE STATISTICS-1976, at 73 tbl.1 13 (1977), with 1993 SOURCEBOKok, supra nute 8 . at 32 tbl 125

90. See supra text accompanying note 11 .

91. See Civil Rights Attorney's Fees Awards Act of 1976. Pub L. No 94-559. 90 Stal 2641 (coditied at 42 U.S.C. $\$ 1988$ (b) (1994)).

92. See Monell v. Department of Soc. Sen's. 436 U S 658 (1978), see also 42 U S C 1983 (199.4) 
ratio understates the relevant phenomenon, since index crimes do not include drug crime, and drug prosecutions grew steeply during the relevant period.

The last three decades' expansion of the law of criminal procedure has taken place against the backdrop of this rise in prosecutorial budget constraint. As the Supreme Court and lower appellate courts created new bodies of law that offered the possibility of new defense claims and arguments, the effect of those rules was reduced because the constitutional revolution was swamped by a revolution in the incidence of crime. Given that second revolution, it seems plausible to suppose that from the late 1960s onward, many more prosecutors could choose among winners; their level of litigation was much more likely to be dictated by their budgets than by the set of cases before them. ${ }^{93}$ In such an environment, pro-defense changes in the law would not seem very costly, since they would neither substantially decrease criminal convictions nor substantially raise the average cost of prosecution. ${ }^{94}$ In a low-crime society (more precisely, a low crime-to-law-enforcement-budget society), the legal changes that the Warren Court inaugurated might have been very costly indeed. In the high-crime society we have inhabited since the late 1960s, those changes appear fairly cheap.

Indeed, the average cost of prosecution has almost certainly fallen during the period of criminal procedure's vast expansion. That seems odd, for the many bodies of law the courts have created to regulate criminal investigation and prosecution are in some sense designed to impose additional costs on the government. More regulation is supposed to mean higher cost and higher quality, coupled with lower quantity. But rising crime rates mean more strong cases, giving police and prosecutors the option of being more selective. The strength of the marginal case is likely to increase, as is the proportion of cases that appear to be clear winners for the government. This seems to be what happened in the 1960s and 1970s: The rate of guilty pleas rose steadily during that period, even while the law of criminal procedure was imposing ever more restrictions on police and prosecutors. ${ }^{95}$

93. This is one of the lessons of the literature on "net widening." See, e.g., James Austin \& Barry Krisberg, Wider, Stronger, and Different Nets: The Dialectics of Criminal Justice Reform, 18 J. RES CRIME \& DELINQ. 165 (1981). Austin and Krisberg point to a number of 1970s-cra reform efforts that followed this pattern: Legislatures created a low-cost case-processing mechanism with the idea of diverting some offenders from the more expensive prison system; prosecutors then used the low-cost mechanism not to reallocate existing categories of cases (as intended), but to add new cases to the system-to widen the system's net. See id. at 169-74. They also note that legislative decriminalization of some kinds of drug and sex offenses, rather than reducing the number of offenders in the system, freed up officials to pursue other crimes. See id. at 176-77. Both patterns suggest prosecutors functioning at capacity, with the constraint on the volume of charges flowing from budgets, not from the number of convictable serious offenders.

94. This point goes far toward explaining Gerald Rosenberg's finding that dramatic changes in the law of criminal procedure had little practical impact. See Gerald N. ROSENBERo, THE HOLLOW HOPB: CAN Courts Bring ABout Social Change? 314-35 (1991).

95. In 1962, a sample of 28 counties found a guilty plea rate of $74 \%$ for defendants with assigned counsel and $48 \%$ for defendants with retained counsel. See SilVERSTEIN, supra note 7, at 22-23. By the mid-1970s, the rate for defendants as a whole had risen significantly, often exceeding 80\%. See DAVID A Jones, Crime Without Punishment 44 tbl.4-1 (1979). By 1987, the rate for felonies was 91\%-and 
I will return below to how this development may have affected the Supreme Court and the rest of the appellate coun system. For now, it is enough to note that the costs of the massive increase in legal regulation of the criminal process have been hidden by a coincidence. Crime rates took off at about the same time that the criminal procedure revolution took off. Critics of the Warren Court tried to claim that the latter phenomenon caused the former. that higher crime rates were the consequence of changes in constututional doctrine. The claim is implausible, as suggested by the past generation's sharp rise in crime rates elsewhere in the Western world, where Earl Warren's writ did not run. ${ }^{97}$ The true causal connection may be close to the opposite of the one claimed by the Court's conservative opponents. Higher crime rates made the post-1960 constitutional revolution cheap and therefore, perhaps, palatable. In another era, one with much less crime, the regime the Supreme Cour created beginning in the 1960 s might have come crashing down, defeated by a public outcry at the spectacle of police and prosecutors sitting on their hands while large numbers of serious criminals walked away free. In our era, a lot of criminals may walk away, but no one is sitting on his hands, and even the police and prosecutors say that constitutional law costs them little. ${ }^{\text {y3 }}$ Far from Earl Warren generating the rise in crime, in all probability the rise in crime has cemented Warren's work in the law of criminal procedure.

\section{Defendants' Wealth and the Cost of Prosecution}

The key effect of criminal procedure doctrines on prosecutorial charging

felonies tend to plead at a lower rate than misdemeanors See BOLAND teT AL. supra nute 83 . at 3

96. See infra Section ill.C.

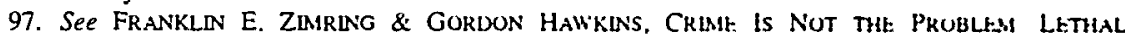
VIOLENCE DN AMERICA $24-29$ (1997) (discussing the parallel nse in theft rales in the linted States and other Western countries between 1950 and 1990) As James Q Wilson notes

When the United States experienced the great increase in crnme that began in the early

1960 's and continued through the 1970's, most Amentans "sere inclined to stubute it to conditions unique to this country. Many conservalues blamed it on judictat restrants on the police, the abandonment of capital puntshment, and the mollycoddling of uflenders, msny liberals blamed it on poverty, racism, and the nse of volent television programs

Now, 30 years later, any senous discussion of cnme must begin with the tatt that. except for homicide, most industrialized natuons have cnme rates that resemble those th the Linted States.

James Q. Wilson, What To Do About Crme. Commentaky. Sept 1944, at 25

98. An American Bar Association survey, pubished in 1988, found widespread dgreement anung police and prosecutors with the proposition that neither the exclusioniry rule nur constutuonal limits un police intertogation impose substantual costs on them. See AMtRICAN BAK ASS'N SPtCLL COMM UN Criminal justice in a Free Societr, Criminal justice in Crisis 12-20, 28-30. 33 (1988) Pul Cassell has criticized the portion of the survey that deals with polsce views stout police interrogetion doatnne, Cassell suggests that the survey understates police opposition to that docinne See Paul G Cassell, $A l l$ Benefits, No Costs: The Grand Illusion of Miranda i Defenders. $90 \mathrm{NW} \cup \mathrm{L}$ R+V IOS4. 1109-10 (19\%6) Even granting Cassell's cnticisms, the surpnsing pount is not that some police oflleces tind biranda doctrine objectionable, but that many do not. The ABA survey is latrly powertul evidence that criminal procedure's regulated actors, who might be expected to be uniformly hustlle to the regulatson. dre mustly indifferent to it. 
decisions is likely to be distributive: Prosecutors probably do not charge less because of the law of criminal procedure (at least not much less), but they may charge differently. The biggest difference is probably an exaggerated class bias. Developments in the law of criminal procedure over the past three decades have substantially raised the cost of prosecuting defendants with money. Clients with the resources to pay for an aggressive defense can take full advantage of the large bodies of Fourth, Fifth, Sixth, and Fourteenth Amendment law that govern the criminal process. In a world where defendants have a high degree of constitutionally protected control over the presentation of their cases, such clients can also drag out criminal proceedings (including pretrial proceedings), making prosecution potentially very expensive.

Given the low level of funding of appointed defense counsel, the law of criminal procedure has a much smaller effect on the cost of prosecuting the run-of-the-mill armed robbery suspect without the funds to hire a lawyer. That suspect cannot fully exploit criminal procedure's many rules, because his statepaid lawyer cannot afford to litigate aggressively enough. For the same reason, the prosecutor need not fear an O.J. Simpson-style drawn-out proceeding: The lawyer's resource constraints are too severe-far more so than any limits trial judges might impose were they free to do so. Constitutional regulation of the criminal process makes some armed robbery cases unwinnable for the government, and may make many such cases slightly more expensive. But it does not make them vastly more expensive.

From the standpoint of prosecutors making charging decisions, it is the relationship between these two sets of cases that matters, the size of the gap between the cost of prosecuting the rich and the cost of prosecuting the poor. Given high crime rates and low pay levels for appointed defense counsel, criminal procedure makes that gap very large indeed. High crime rates make for a large supply of easy cases with either appointed counsel or low-paid private counsel. Low pay rates make those cases cheap to litigate. Thus the opportunity cost of charging one high-profile well-to-do defendant may be dozens of burglaries, robberies, and assaults. Of course, sometimes that cost is worth bearing. Prosecuting an O.J. Simpson or a William Kennedy Smith is a political imperative. But where it is not imperative, where a prosecutor has some room for maneuver, the current regime seems designed to encourage her to substitute poor defendants for rich ones.

A number of phenomena in the system testify to this effect; I will mention two examples. The first is the rise in the percentage of cases in which defense counsel is appointed. Two decades ago, attorneys were appointed in less than fifty percent of criminal cases; today the percentage is eighty. ${ }^{99}$ Courts appoint counsel for defendants who are indigent; the percentage of cases in which courts appoint counsel is thus a decent proxy for the percentage of cases

99. See supra note 7. 
in which the defendant is, by some reasonable measure, poor. And that percentage has risen sharply over the past couple of decades. This is exactly what one would expect in a world where the relative cost of prosecuung poor defendants has declined over time (because the cost of prosecuting rich defendants has increased so much). ${ }^{100}$ To be sure, this change may have its own distinct set of causes; changes in constitutional doctrine are not the only explanation for the phenomenon. It seems plausible to suppose, however, that the combination of higher levels of serious crime (which give prosecutors more flexibility to pick and choose among cases) and heavier constitutional regulation of the criminal process (which pushes prosecutors loward poorer defendants) has been a major contributing factor.

The second phenomenon concerns a category of criminal prosecution that often involves wealthy defendants but that has exploded even as criminal procedure's constitutional revolution has taken hold. As late as 1970, white collar crime was a fairly small field. ${ }^{101}$ Today, there is a large white collar defense bar in major cities, and some United States Altorneys' offices do an enormous amount of white collar work. ${ }^{102}$ But note where the explosion has come. White collar crime has not just grown; it has been federalized. The criminal law of fraud was traditionally a state affair. That kind of white collar criminal prosecution has been superseded by federal mail and wire fraud statutes, securities regulation, banking regulation, and the like.

The system's growing wealth bias cannot explain why white collar criminal enforcement has grown-that phenomenon is probably the product of other, more political forces-but it can explain why this field has become a federal enclave. Almost by definition, white collar crime tends to involve defendants with money. ${ }^{103}$ It also requires investigation of documents and

100. One might respond that the tuming is ofl, and that the percentage of indigent defendants should have risen most dramatically in the 1960s, not in the 1970s and 1980s The response is incorrect lur two reasons. First, the explosion in criminal procedure docinne is not. ds the standard line would hate ul. function of the 1960s. Most constituuonal clams outside the reslm of polsce miscionduct stem Irom leg'sl developments of the 1970s and 1980s. And even within the realm of police miscionduct, these huve been major pro-defense developments since 1970 that have generated latge numbers ol clatus (plus, ut course. the fleshing out of the Warren Court's generalitues) See infra notes 211-219 and accompany ing text

The second reason is more general. One would expect that in umes of grest legisl chunge there would be some time lag-at least a few years, sometumes a decude or more-between doctunal develupments and the litigation those developments spawn. It takes the legal market tume nol simply to absurb the new doctrine, but also to absorb its pracucal ampact on lugatuon strategy That expectatuon is especially lakely to hold true of the criminal process, where the relevant litigation decistons are made quickly. in assembly. line fashion. In such a litigation market, attomey custom is lukely to play a powertul role, and custum iends to change slowly.

101. See, e.g., David Weisburd et al., Crimes of thr Mildile Classts 6-7 (1991)

102. For a good account of the explosion of white collar cnmind practice in New York. Whth a paricular emphasis on the defense bar, see KenNeth MaNis. Derbsidso Whrt: Collak CRLit 19-30 (1985).

103. This is not to say that white collar criminal delendants afe invandbly noh On the contrary, many defendants are close to insolvency, which may help explan why thes fund crime tempung See Weissurd ET AL., supra note 101, at 65 (noting that many white collar offenders "hase the malenal gocods associsted with successful people but may barely be holding ther finsncial selves logether") But even al their 
interviews with witnesses that in turn tend to let the defendant know he is a target. The consequence is often expensive defense maneuvering at the investigative stage, before charges are even filed. ${ }^{104}$ Formal litigation, in those cases that go to trial, can be more expensive still. For local prosecutors, the opportunity cost of this kind of litigation tends to be very high: There are burglaries and rapes and drug deals to prosecute, and those cases cannot simply be dispensed with, for the local population would not tolerate such a policy. For federal prosecutors, the calculus is quite different. On the one hand, federal prosecutors too have a range of cases, many of them easy, that they can choose to pursue, and an expensive securities fraud case may displace a large number of these easier cases. On the other hand, federal prosecutors are not politically accountable to a local population; hence, they can simply dispense with some important categories of crime to concentrate on others. The economics of the two prosecutors' offices may be the same, but the politics are very different.

The point can be generalized. Given high crime rates and a high degree of constitutional regulation of the criminal process, crimes of the wealthy will likely become, more and more, a federal affair. That has obviously happened with offenses like mail fraud, but it extends farther. Federal prosecutors have played an ever greater role in prosecuting drug cases, but the role has not been evenly distributed: Large-scale conspiracy charges and prosecutions of highlevel dealers are increasingly the province of federal officials. ${ }^{105}$ Defendants in these cases often have access to substantial resources, including the resources of a criminal organization that may be funding the defense. These are also cases that commonly raise constitutional claims about the gathering of physical evidence: Most contemporary Fourth Amendment law is made in and for drug investigations. These features make at least a significant slice of drug cases-the cases in which defendants can use the proceeds of the business for their defense--much more expensive for local prosecutors. ${ }^{106}$ The natural response is increasing federalization.

liabilities are substantial, relative to street-crime defendants, white collar defendants' assets are also substantial. White collar defendants are vastly more likely than are street-crime defendants to be employed, to be employed in high status professional jobs, to have college degrees, and to own homes. See id. at 64 65. Not surprisingly, white collar defendants are also much more likely to have privately retained counsel, though a substantial minority do receive appointed counsel. See id. at 100-01 \& tbl.5.2.

104. For a wonderful account, see MANN, supra note 102, passim.

105. From 1982 to 1993, the number of drug trafficking convictions in federal district courts grew from 5377 to 19,228 . See 1995 SourCEBOOK, supra note 83 , at 468 tbl.5.19. One difference between federal and state drug prosecutions is suggested by a recent study showing that while $70 \%$ of defendants in state court drug prosecutions receive appointed counsel, only $48 \%$ of their federal counterparts do. See Smith \& DeFrances, supra note 7, at 3 tbl.4. Presumably this difference llows from federal prosecutors' greater concentration on higher-level defendants, who tend to have more resources.

106. This is so notwithstanding the supposed laxity of Fourth Amendment doctrine in drug cases. The point is not that drug defendants usually have successful Fourth Amendment claims, but rather that they sometimes do, and that successful and unsuccessful Fourth Amendment claims alike are disproportionately located in drug cases. 
There has also been another response. Since the higher cost of prosecutıng stems not only from changes in legal doctrine but also from the defendant's access to money, the law of criminal procedure gives the government a strong incentive to try to take away the money. Hence the increased use of state and federal forfeiture laws as government weapons in criminal litigation. ${ }^{167}$ As in the Caplin \& Dry'sdale case, ${ }^{108}$ the government freezes defense assets that would otherwise be used to pay lawyers on the ground that those assets are probably forfeitable, thereby impoverishing the criminal defense. ${ }^{10 y}$ The statutes that permit this tactic can be seen as legislatures' way of attacking what is otherwise a large wealth advantage enjoyed by a subset of drug defendants. The size of that advantage, in turn, has a lot to do with the law of criminal procedure. Critics of forfeiture proceedings have lended to argue, plausibly, that those proceedings undermine Sixth Amendment law by reducing the level of representation available to the defense. ${ }^{110}$ But constitutional law is itself a major part of the process that has produced forfeiture, because constitutional law has so increased the gap between the cost of prosecuting the rich and the cost of prosecuting the poor.

\section{B. The Defense}

Now consider the rationing process on the defense side. In one sense, that process works the same here as anywhere else: Criminal defendants raise claims if it is worth their while to do so, measured by how costly the claims are to raise and how likely they are to succeed, and not otherwise. That proposition, however, masks the role crime rates and resource allocation decisions play. At least in the many cases where conviction may mean prison, the stakes in criminal litigation have two critically imponant characteristics: They are both extremely large and nonmonetary. The result is a huge wealth effect. If a given defendant has a million dollars in the bank, he might well find it worthwhile to spend it all to achieve a successful outcome-hence the common scenario of white collar defendants impoverishing themselves fighting off criminal investigation. "1" But if the same defendant has only one or two thousand dollars to spend on his defense, the litigation is "worth" one or two

107. The story is told in Pamela S Karlan. Discrete and Relathonal Cruminal Representunon The Changing Vision of the Right to Counsel, 105 HARV L REV 670. 703.11 (1992)

108. Caplin \& Drysdale, Chartered v United States, 491 U S 617 (1989)

109. Pamela Karlan has argued that Caplin \& Drisdale can be seen as an effort to thus urt the use of criminal defense lawyers to add value to crimunal enterprises See Karlan, supra nute 107. At 710

110. See, e.g., Todd Bamet \& Ivan Fox, Trampling on the Strth Amendment The Contumed Threat of Attomey Fee Forfeiture, 22 OHIO NU L. REV 1 (1995)

111. This phenomenon was at the hear of Congress's deciston to suthorke rembursement of attorneys' fees incurred by never-indicted targets of independent counsel invessigations See 28 U S C \$ 593(f)(1) (1993). For a good discussion, see Pamels $S$ Karlan. Commingent Fees and Crumunal cases. 93 COLUM. L. REV. 595, 636-37 \& nn.160-62 (1993) 
thousand dollars-even though the potential sanction and the chances of avoiding it have not changed.

For the roughly eighty percent of defendants who receive appointed defense counsel, the case is "worth" whatever price the state sets. The state, in turn, sets that price in a combination of two ways. The first is by funding public defenders' offices, which are then given all or almost all the indigent cases in the relevant jurisdiction. The second is by fixing an hourly rate up to a fee cap for state-funded private counsel. ${ }^{112}$ At current funding levels, the effective price is low under either regime. ${ }^{113}$

This regime leads to two kinds of biases in the incidence and distribution of criminal defense litigation. In many, perhaps most cases, the existing funding system promotes underlitigation, with defense counsel failing to contest cases as aggressively as they should due to a lack of resources. The second bias is less obvious but may be more problematic. The current regime leads to a different mix of litigation, with constitutional claims displacing factual investigation and argument.

\section{Underlitigation}

At the outset, one might suppose the existing system produces too much litigation, not too little. There are some cases in which the proper level of defense litigation is near zero: The case is easy on the merits, the defendant admits guilt, there are no apparent constitutional claims, and the prosecution has offered substantial sentencing concessions. In a system with state-paid counsel, defendants may contest these cases too aggressively. A defense attorney gets paid whether she wins or loses, and since the pay does not come from the client, the client does not mind litigation that wastes the prosecutor's and the court's time. This is presumably part of the reason why states have low fee caps for separately appointed defense counsel. The fear is that counsel has no reason apart from the cap to stop litigating. The result, one might think, is a regime with too much litigation in easy cases and too little in hard cases.

There are, however, a variety of reasons to discount the "too much" problem. Since fee caps are low, cases taken to trial tend to be money losers. By refusing to make plea concessions, prosecutors often can, in effect, force defense counsel to take cases to trial. Of course, the prosecutor loses when this happens, but defense counsel loses more, particularly since the prosecutor has an option defense counsel does not have: She can get rid of some cases to make room for others; that is, she can control the size of her docket. For

112. A third, less common, method is to contract with firms or individual lawyers for representation of a class of indigent defenders. For a recent survey of methods of assignment and funding, see Robert $L$. Spangenberg \& Marea L. Beeman, Indigem Defense Systems in the United States, LAW \& CONTEMP. PROBS., Winter 1995, at 31, 32-53.

113. See supra notes 20-31 and accompanying text. 
defense counsel, the size of the docket is more like an extemal constrant This asymmetry creates something like a chicken game between a Lexus and a Hyundai. Both sides are harmed by the collision, but one is harmed much more, and the side with more to lose is in the weaker negotiating position. Prosecutors' ability to threaten loss is thus a useful tool for punishing overlitigation by appointed counsel and hence for inducing more cooperatuve (meaning less litigious) behavior. The plea bargaining literature contains some anecdotal evidence that prosecutors behave in precisely this fashion. ${ }^{11+}$

Then too, hourly rates for appointed counsel are, in many jurisdictions, less than generous. ${ }^{115}$ Even for lawyers who enjoy little financial success, these rates may be no greater than the opportunity cost of the lawyer's time. Finally, the incentive to overlitigate is basically absent in cases involvang public defenders. Their compensation is not limited in any given case; it is limited across a set of cases. Consequently, public defenders must ration their time across the board; the marginal benefit of investments in any given case is not discontinuous, as it is for separately appointed counsel subject to fee caps. All of which suggests that, given existing conditions, the degree of overlitigation must be very small. ${ }^{116}$

The more serious problem is too little litigation. Appointed defense counsel litigate less than high-end private counsel because they cannot afford to do otherwise. The resulting shortage of litigation takes three forms. First and most obviously, defense counsel sometimes press their clients to plead guilty, since taking a high percentage of cases to trial is unaffordable. "7 The second form shows up in those cases that do go to trial: Even where charges are contested. the contest is less aggressive than it would be if defense counsel were funded

114. See, e.g., HEUMANN, supra note 76 , at $122-26$

115. See supra notes 23-26 and accompanying text

116. Of course, in different conditions overlitgation might be a grester concern ll fex asps and huutly rates were much higher, separately appointed counsel's meenuve to litigale would stso be much higher, and prosecutors' ability to induce cooperatuve nonlugation would be reduced At current pay idtes, huwerer, overlitigation seems to be a minor problem even for that subset of appointed detense counsel Fur public defenders, one might suppose that overlitggation would remaln a small problem even il lunding were dramatically increased. Because they are sulaned employeses, public detenders gun nuthung trum the marginal hour in coun, and they lose an hour that could be spent sumewhere else

117. This point is barely acknowlodged in the recent outpounng of litersture on spputnted detense counsel, presumably because counsel themselves tend not to diknow ledge " Cf MtCWTrkt, supra nute 22, at 154-56 (reporting that some public defenders concedeal pressing clients to pledd guilty, but dented that this behavior was the result of docket pressure) But delendants do Sre ROBrkT lirkMANT kT AL.

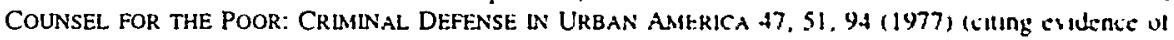
defendants' perceptions that public defenders pressure them to pledd guiliy). of Schulholer \& Frtedman. supra note 32, at 86 (discussing defendants' perception that public detenders ate part of the judictal bureaucracy).

The tendency to push for gulty pleas as a response to resource constrants is une of the primary sources of academic attacks on plea barganning See. e 8 . Stephen J Sihulhoter. Plea Burganung as Disaster, 101 YALE L.J. 1979, 1988-90 (1992) Yet the problem is not ples batgunning but the resuurce constraints. The pressure to plead would exisi even a prosecuturs were lorbidden to vilet explutl concessions, as long as defense attorneys faced severe cost pressures 
more generously. Resources limit the time invested in selecting a jury, the number of witnesses called, and the lines of factual argument pursued. ${ }^{118}$

Third, resources limit constitutional litigation. The regulatory provisions of the law of criminal procedure presuppose that defense counsel will object when constitutional violations occur. That is how regulated actors-chiefly, but not solely, the police-receive the signal that they need to adjust their behavior. Resource constraints impose a ceiling on how many things counsel can object to, how many claims can plausibly be raised. The result is that claims must cross a higher threshold in order to get appointed counsel to raise them, or raise them aggressively. ${ }^{119}$

Of course, less litigation is not the same as too little litigation. Perhaps, one might argue, the current system is wise to ration so severely. The large majority of defendants presumably are guilty, and many of them will have no plausible legal claims. The system would do well to focus its attention on the most problematic cases. On this view, we have created a system with great litigation opportunities coupled with serious resource constraints in order to ensure that the opportunities are used wisely, that litigation dollars are spent on the strongest claims for the most deserving defendants.

That argument is hard to answer in the abstract. One's conclusion depends on how much defense litigation one thinks appropriate, and the right baseline is not obvious. But comparing cases with and without appointed counsel is

118. These statements are obviously true, yet evidence for them is hard to come by. The reason, as Malcolm Feeley has noted, is that the literature tends to compare appointed counsel to all retained counsel rather than to well-paid retained counsel. See Malcolm M. Fceley, Bench Trials; Adversariness, and Plea Bargaining: A Comment on Schulhofer's Plan, 14 N.Y.U. REV. L. \& SOC. CHANGE 173, 174 (1986). It is probably the case that most retained counsel are retained by defendants whose finances place them only slightly above the indigency line. Often such counsel do no better-indeed, may do worse-than the counsel indigents receive. See, e.g., JAMES EISENSTEIN ET AL., THE CONTOURS OF JUSTICE: COMMUNITIES AND THEIR COURTS 289 (1988). But cf. infra notes 120-124 and accompanying text (noting evidence that, on some measures, retained counsel litigate more aggressively and achieve better results).

Feeley concludes that worrying about the level of resources for criminal defense is largely beside the point, for "it is unrealistic to expect that public sector services for the indigent-including criminal defendants-will ever be much better than what is available in the market to those who can barely pay for services." Feeley, supra, at 174-75. The upshot, he says, is that we cannot substantially improve the lot of indigents in the existing system without socializing criminal defense. See id. at 175. This is incorrect. Were the state to fund criminal defense substantially better, it would presumably raise the indigency bar accordingly-indigency logically ought to depend on whether a defendant could purchase a level of representation comparable to what the state gives those with no money. Cf. Donna L. Hall \& Jonathan E. Gradess, Determining Client Eligibility for Appointed Counsel: A Strategy for Reform in New York State, 14 N.Y.U. REv. L. \& SOC. CHANGE 119 (1986) (describing and criticizing the existing system by which indigency is defined). It seems to follow that more money for criminal defense would mean more indigent defendants. But there is a counter-tendency: More money for criminal defense would reduce the gap between the cost of prosecuting defendants with and without resources, which would reduce the government's incentive to prosecute poorer defendants. See supra Section Il.A. Over time, then, the percentage of indigents might actually go down in a better-funded system. It is precisely the poverty of criminal defense in the existing system that pushes toward a socialized system; better funding might have the opposite tendency.

119. See, e.g., Michael McConville \& Chester L. Mirsky, Criminal Defense of the Poor in New York City, 15 N.Y.U. REv. L. \& SOC. CHANGE 581, 766-69 (1986-1987) (summarizing evidence of the failure of appointed defense counsel in New York to engage in substantial motions practice). 
instructive. When defendants do have resources, they spend them. The result is higher levels of litigation among those who can hire lawyers than among those who must take what the state gives them. Privately paid counsel file more motions than do state-appointed counsel. ${ }^{130}$ Defendants with private counsel see their lawyers sooner than do those with appointed counsel. ${ }^{131}$ When they plead guilty, defendants who hire their own lawyers do so later, after the lawyers have had more opportunity to investigate the case."' And though early studies showed that defendants with retained and appointed counsel had similar outcomes, ${ }^{123}$ some more recent studies suggest that defendants with retained counsel do significantly better. ${ }^{13:}$ These effects presumably grow as the level of resources available to pay counsel grows: Consider the length of, and attorney investment in, trials like O.J. Simpson's. If defendants who can afford to hire counsel litigate properly, it follows that indigent defendants do not litigate enough.

\section{Differently Distributed Litigation}

\section{a. Why Some Claims Displace Others}

Thus far the argument has suggested, unremarkably, that poorly funded appointed counsel will litigate a lot less than well-funded privale counsel. The

120. See Pauline Houlden \& Stephen Balkin, Quahn and Cost Comparisons of Pra ate Bar Indigent Defense Systems: Conract is. Ordered Assigned Counsel. $76 \mathrm{~J}$ Ckm L \& Chustivougr 176. 190 (1985)

121. A survey of inmates of local jalls indicalid that $69 \%$ of those who hurd a law yer had met wath her within a week after detention, compared to $47 \%$ of those who recelved stute-appomiled counsel sie Smith \& DeFrances, supra notc 7, dt 4 tbl 7

122. See HANSON ET AL., supra note 22, at $43-1$ (10portung thall. in a study ut nine cours in communities of varying sizes, the average number of days from churging lo adjudicalion was 103 in cases with assigned counsel, 128 in cases with public defenders, and 160 in (ases with fetaned counsel). Puuline Houlden \& Steven Balkin, Costs and Qualin of Indigem Lefense Ad Hoc is Coordinated Assignment of the Private Bar Within a Mixed System, 10 JUST SYS J 159.165 (1985) (reponing the results ul a study showing similar results of 105.7 days for ad hoc assigned counsel and 1203 das sor retained counsel)

123. See Floyd Feeney \& Patrick G Jackson. Public Defenders, Assigned Coumsel. Refunted Counsel Does the Type of Criminal Defense Counsel Matter". 22 RLTGERs L J 361. 365-78 (IW) ) (discussing pte1980 studies).

124. See Dean J. Champion, Prnate Counsels and Public Defenders A Look at lieak Cases Prior Records, and Leniency in Bargaining. 17 J. CRIM JUST 253. 258 (1989) (repontung that retuned cuunsel are more likely to take cases to tnal and more likely to obtan sequituls). Stesens $H$ Claske \& Sus.an $T$ Kurtz, The Importance of Interm Decisions to Felon, Trual Courl Disposuriuns, 7t J CktM L \& CRRMINOLOGY 476, 507 (1983) (finding that retaned counsel are more likely lo ubisin dismissal and that their clients are more likely to avoid proson sentences in nonviolent felony cuses). Joyce $S$ Sterling. Retained Counsel Versus the Public Defender: The Impact of Tipe of Counsel an Charge Barganng. "In THE Defense Counsel 151, 160-62 (Willam F MicDonald ed. 1983) (statung that retuned counsel afe more likely to obtain deferred disposition or charge reduction)

The gap between retaned and appointed counsel would no doubs be larger but lor the lat that 4 significant portion of retained counsel are patd esther no better of only slightly better then sppounted counsel. See EISENSTEIN ET AL., supra note 118, at 289 For example, when white collat delendants, who are likely to exceed the indigence threshold by a substantial margin. are compared wath ordinary streetcrime defendants, the large majority of whom are esther indigent or cluse to 11 . a substantual gap in the tate of guilty pleas appears. See WEISBURD ET AL, supra note 101. a 113-14 (finding that white collat defendants go to trial four tumes as often as defendants in street-crime cases) 
more interesting and more disturbing possibility is that appointed counsel will litigate differently. Imagine two civil defendants, both sued for $\$ 50,000$, one of whom has privately paid counsel while the other is given state-appointed counsel paid a modest hourly fee up to a $\$ 2000$ cap. Three different legal defenses are potentially available to these civil defendants. Any of the defenses would win the case if successful; each is independent of the others; each costs $\$ 1000$ to raise; and each has a $10 \%$ chance of success. In this scenario, the defendant with private counsel will press all three claims, while his counterpart will litigate only two.

Now add another piece to the puzzle: Suppose the relevant jurisdiction has just generated a new defense claim. It too costs $\$ 1000$ to litigate, but it has a slightly higher chance of success-say, $15 \%$. The richer defendant will now raise four claims rather than three. The poorer defendant will substitute the new claim for one of the others, thereby slightly raising his likelihood of success. But he will still raise only two claims.

Note the effect of the new claim. For the defendant with resources, it raises the level of litigation, since the stakes make it worthwhile to use all weapons the law might make available. For the poorer defendant, the stakes are not the decisive factor; the attorney's fee is. Consequently, for that defendant, the legal change alters the distribution of defense litigation but not its level.

The picture is of an archery contest where each contestant is given three arrows and three shots at the target. Just before the contest is to begin, all the contestants receive three more arrows. But while a few contestants are, like the rich defendant, allowed to fire all the arrows they have, the large majority must still make do with only three shots. For most contestants, more ammunition does not mean more shots fired, and (depending on the difference in quality of the arrows) it may have only a slight effect on how particular contestants perform. Its primary effect may be to change which arrows contestants pull from their quivers.

That is a fairly accurate picture of criminal litigation and its relationship to changes in the law of criminal procedure. For defense attorneys paid at an hourly rate up to a low fee cap, the picture captures attorneys' litigation incentives quite well. For public defenders the story is more complicated, though the essential point remains the same. Recall that salaried public defenders, like prosecutors, must ration their time across a set of cases. If the set is large enough (as it appears to be in most public defenders' offices), the level of litigation is essentially at capacity. Additional claims and arguments in one case must mean less aggressive litigation somewhere else. Once again, the prime effect of more constitutional regulation is not so much to increase the level of litigation as to change its distribution. Some claims displace others.

It follows that, given anything like the current allocation of funds to the system, constitutional law faces a different set of choices than the ones usually 
discussed in Supreme Court opinions and law review articles. The question is not whether greater regulation of jury selection or police searches and seizures is a good thing in itself, but whether it is worth some loss of enforcement of, say, Miranda or double jeopardy law. Given the enforcement regume, defendants' rights are in competition with each other.

In itself, that is not necessarily a large problem. It is not obvious that the system does or should have strong preferences among various crimnal procedure claims. Encouraging litigants to select among possible claims based on the cost and strength of each claim may be sensible. To be sure, the presence of tradeoffs between different claims may say something about the regulatory weight the system can carry. One might value Mirunda, search and seizure law, double jeopardy law, and Batson doctrine equally, yet still prefer aggressive enforcement of any two of these bodies of law to low-level enforcement of all four. But one might also have the opposite preference Large numbers of potential claims coupled with severe resource constraints may allow the law to regulate a wide variety of areas without having the system grind to a halt.

The real problem with the archery contest stems from the possibility that some arrows are special, that some claims matter more than others. If, for example, we should prefer the marginal valid Miranda claim to the marginal valid grand jury discrimination claim, or vice versa, the compettion among claims becomes a serious issue.

\section{b. Procedural Claims and Factual Claims}

Enter merits litigation. One kind of argument defense counsel can make on behalf of her client goes to whether the client, in fact, committed the crme charged. Perhaps the defendant has an alibi, or acted in self-defense, or lacked the requisite mens rea. Those arguments do matter more than other sorts of arguments raised in criminal litigation; most people would agree that the system should seek to minimize convictions of innocent defendants. This preference for skewing the risk of error in the defendant's favor does not apply to most constitutional claims, where the system can tolerate a much higher level of pro-government error: Better that an occasional Fourth Amendment violation or Batson claim be overlooked than that an occasional innocent defendant be imprisoned. This explains the system's different rules on burdens of proof: Guilt must be proved beyond a reasonable doubt, ${ }^{125}$ but exclusionary rule claims (for example) are often rejected unless the defendant proves by a preponderance of the evidence that the search was illegal. ${ }^{130}$

125. See In re Winship, 397 U.S. 358 (1970)

126. The standard rule in search and seizure cases is that the detendant bears the burden of prowng that a "search" or "seizure" took place; at that point, the burden of proving reasunableness shults to the government if the search or seizure was warrantless, but the burden remains on the delendant if the police 
Crucially, though, satisfying these common preferences concerning the distribution of errors on different kinds of claims also requires adequate levels of litigation in the respective categories. If marginal search and seizure claims tend to be raised while marginal merits claims are not, the error rates in the two categories will have the wrong relationship. Too many innocents will be convicted, not because their arguments are pressed unsuccessfully, but because those arguments are never raised. And, perhaps, too many marginal search and seizure claims will succeed-again, not because courts are too favorable toward such claims, but because too many are litigated.

To some degree, the current system encourages that result. Consider the relative cost of raising a search and seizure claim and a self-defense argument. The search and seizure claim has many advantages. Such claims are easy to raise; counsel need only file a boilerplate motion. The facts on which they rest usually do not involve much independent digging by defense counsel. The typical suppression hearing is nothing more than an adjudication of the plausibility and legality of the police officer's version of events. This adjudicative process requires neither detailed papers nor a complicated jury proceeding, merely a brief hearing with one or two witnesses before a judge. ${ }^{127}$ And the benefits of a successful claim are sometimes enormous-it can mean dismissal of all charges. Even where that is not the case (as it often is not), ${ }^{128}$ suppressing some evidence can bring about a charge reduction and a more favorable plea bargain. This leads to one final, critically important point about the cost of invoking the exclusionary rule: One can file and litigate suppression motions without going to trial. The system is designed to facilitate fast-track pretrial litigation that can then set the stage for either dismissal or a plea agreement, precisely the kind of process that is least expensive for overburdened defense counsel to invoke.

The self-defense claim, meanwhile, will likely involve substantial digging. Among other things, counsel will have to investigate in detail any prior relationship between the victim and the defendant, since that relationship will

acted pursuant to a warrant. In addition, defendants bear the burden of establishing both standing to raisc a Fourth Amendment claim and the causal connection between the asserted constitutional violation and the discovery of evidence. See 5 LAFAVE, supra note $59, \S 11.2(\mathrm{~b})$, at 37-57.

127. Sometimes no papers need be filed; an oral motion will suffice. $C f .2$ Anthony G. AMSterdaAm, TRIAL MANuAL for the DEFENSE of CRIMINAL CASES $\$ 222(A)$, at 3-4 (1989) (advising defense counsel to submit a written motion even where an oral motion is permitted). Interestingly, the leading defense trial manual advises counsel to keep suppression motions spare in order to avoid giving police information about the defendant's legal theory. See id. $\S 222(B)(2)-(3)$, at 4-5. The same manual, in discussing the presentation of evidence at suppression hearings, focuses on the testimony of the arresting officer and the defendant, see id. $\S 253(\mathrm{E})$, at $169-72$, presumably because most suppression hearings involve testimony from no one else.

128. The link between suppressing evidence and dismissal depends on the kind of evidence suppressed. Peter Nardulli's study of exclusionary rule litigation in Chicago found that the vast majority of successful motions to suppress physical evidence resulted in dismissal or acquittal, while the conviction rate dropped by less than one-third when incriminating statements were suppressed. See Peter F. Nardulli, The Sociefal Costs of the Exclusionary Rule Revisited, 1987 U. ILL. L. REV. 223, 233. 
tend to determine the plausibility of any claim that the victim was the true aggressor. It is also costlier to pursue than the Fourth Amendment claim. If the government fights the suppression motion, the upshot is a brief suppression hearing; if the government fights a self-defense argument, the upshot is a jury trial, and jury trials are more involved and require more preparation than suppression hearings. And the self-defense claim is generically no more likely to succeed. Defendants win about one-sixth of contested suppression motions; ${ }^{129}$ the acquittal rate for felonies that go to trial is similar. ${ }^{130}$

That much suggests a substantial incentive on the part of defense counsel to prefer some kinds of procedural litigation to some kinds of merits litigation. Of course, other incentives operate: A successful merits claim usually leads to complete victory, ${ }^{131}$ while a successful suppression motion often does not. Moreover, the successful merits claim may offer more satisfaction to defense counsel than victory via Fourth Amendment litigation. Counsel have other motivations besides minimizing cost; many public defenders have their jobs precisely because of their desire to prevent serious injustices. That desire, one might suppose, would counterbalance the cost differences that seem to tilt against factual arguments on the merits.

Yet even if this is so, ${ }^{132}$ defense counsel are rarely put in the position of

129. See Peter F. Nardulli, The Societal Cost of the Exclustonan Rule: An Empincal Assessment, 1983 AM. B. FouND. REs. J. 585, 590, 596 (finding a success rate of $169 \%$ on motions to suppress phystcal evidence in a study of nine counties). One might faurly ask why this perientage is so high in exonomic terms, defense counsel have an incentuve to invest in clams unul their marginal return is equal to the marginal return of alternative investments. Given the low cost of suppression hearings relattve to thals. that should produce a mix of litigation that is ulted heavily toward suppression motions-lawyers should be much more willing to press low-probability Fourth Amendment clums than low-probabluty ments claims The rough equivalence of success rates at inal and in suppression heanngs suggests this dues not happen

There are two likely explanations. Furst, suppression motions are less likely to produce tolal vitury than are trial defenses-that is, even successful Fourth and Fifth Amendment clatms often produce convictions on some charge, see stupra note 128 , while successtul clams on the ments generally lead to a dismissal or an acquittal. Second, defense attorneys and prosecutors are repeat players in the pled bargaining process, and prosecutors have both the incentuve and the sbility to punish what they see as excessive pretrial litigation by defense altomeys See HeUManN, supra note 76, at 131-38 Defense attorneys who make a habit of filing one-in-a-hundred suppression motions will find, in many junsdictiuns. that their clients do not receive the charging and sentencing concessions that other detendants get

130. See 1993 SouRCEBOOK, supra note 8, al 546 tbl 573 (finding in a survey of the nation's 75 largest counties that $6 \%$ of all defendants are convicted of telonies $d$ inil while $1 \%$ of 4 ll delendants dre acquitted). An earlier study, closer in time to Nardullı's study of suppression mutions, see Nurdullı, supra note 129 , found $5 \%$ of all defendants convicted of felonies al inal and $1 \%$ acyumlled Sre Bukbau or Justice Statistics, U.S. DeP'T OF JUSTICE. SOURCEBOOK ON CRIMINAL Justick-1989. al 525 ibl 550 (Timothy J. Hanagan \& Kathleen Maguire eds., 1990).

131. Usually, but not always. Successful mens rea argumenis ean reduce the grade of ollense without leading to nonliability, as where a murder charge leads to a manslaughter conviction Imperfect self-defense and provocation claims function the same way. These kinds of ments arguments have results analogous to successful suppression mottons that remove some. but not all. of the government's case, and thereby set the stage for a more favorable plea bargain.

132. It may not be. Far from counteracting the cost differences, the culture of enminal defense counsel may reinforce them. In pan because so many of their clienis are certan to lose. public defenders have long seen themselves not as defending the innocent or helping the system separate the innocent from the guilty. but as fighting the system, gaining victories (whole or parual) as often as possible and :n any (legal) way possible. See, e.g., HERMANN ET AL., supra note 117, at 85 (discussing a 1970s study of cnmmal delense counsel noting that New York City Legal Aid lawyers were cnucized for trying to "fight the system and 
choosing whether to file this suppression motion or raise that factual claim - the kind of choice that would highlight the tradeoff between merits and non-merits litigation. The far more common choice is whether to file the motion or investigate the factual claim. Factual arguments are not merely harder to prepare and pursue than legal claims; they are harder to evaluate. And quick evaluation is key. In a system in which ninety-plus percent of convictions are by guilty plea ${ }^{133}$ and in which public defenders represent hundreds of felony defendants per year, ${ }^{134}$ defense lawyers' most important job is triage: deciding which (few) cases to contest somewhat, which (very few) cases to contest seriously, and which ones not to contest at all. Nor can clients be trusted to sort themselves: If it is worthwhile for defendants to claim innocence, all will do so. ${ }^{135}$ In such a world, factual arguments-claims that the defendant did not do the crime, or acted in self-defense, or lacked the requisite mens rea-tend to require nontrivial investigation simply to establish whether there is any argument to make. Most possible challenges to the legality of a police search, meanwhile, appear on the face of the police report. (If the police searched the defendant's house, did they get a warrant? If they discovered drugs in the course of a traffic stop, was the stop justified?)

The relevant choice, therefore, is not whether to file a suppression motion or make a self-defense argument, but whether to file the motion or find out if the argument even exists, in a world where it probably doesn't. Given how cheap is the process that decides the suppression motion, and given the expense of both determining whether the self-defense argument is worth making and actually taking that argument to trial, the system places substantial pressure on counsel to opt for the procedural claim rather than the (potential) substantive one.

This point extends beyond Fourth Amendment claims and self-defense arguments. In general, arguments about the merits of criminal charges are factintensive and hence require significant investigation even to determine whether

make a statement" or wage "personal warfare against the system"). For a more recent study that reaches a similar conclusion, see Debra S. Emmelman, Defending Indigents: A Study of Criminal Defense Work 30, 367 (1990) (unpublished Ph.D. dissertation, University of California (San Diego)) (on file with the Yale Law School Library). For a defense of this "fight the system" mentality, sec DAVID LUBAN, LAWYERS AND JUSTICE: AN ETHICAL STUDY 58-65 (1988). This psychology is probably inevitable and it may be, on balance, socially beneficial. But it pushes defenders to think of suppression motions and self-defense claims as substitutes-different tools toward the same end. Society no doubt has a rank ordering in mind, with some kinds of defense victories strongly preferred to others. Defense counsel may not share the same vision, and their natural incentive is to value all victories equally.

133. See supra note 83 and accompanying text.

134. See supra note 20 and accompanying text.

135. This is presumably why criminal defense counsel report a high level of dishonesty among their clients. Milton Heumann quotes the following statement of a state court criminal defense attorney: "[T]he first year you practice law you believe everything your client tells you. The second year you practice, you believe everything that the other side tells you. The third year you don't know who's telling the truth. Most people tend not to believe their clients that much, justifiably." HeumanN, supra note 76, at 59 . For a discussion of the problem this sort of client dishonesty creates for plea bargaining, see Robert E. Scotl \& William J. Stuntz, Plea Bargaining as Contract, 101 Y ALE L.J. 1909, 1935-49 (1992). 
the argument is worth raising, and such investigation is costly, especially in a regime with severe resource constraints. Some constitutional claims require factual investigation as well (think of grand jury discrimination claims ${ }^{136}$ ), but most do not (consider most challenges to the jury selection process ${ }^{137}$ ), and those that do require some digging rarely require much (as with police interrogation or search and seizure claims, where adjudication often turns on the testimony of the police officer and oral argument by the attorneys). Finally, as with search and seizure claims, a large number of constitutional claims can be raised in low-cost pretrial motions that tend to serve as preludes to either dismissal or a plea. Factual claims are placed on a much costlier litigation track. These differences give constitutional litigation a major cost advantage over most kinds of challenges to the merits of criminal charges.

None of this means there is a one-to-one displacement of merits arguments by procedural claims. On the contrary: One can file and litigate several suppression motions in the time it takes to prepare and try one felony case. But there is some displacement, and its effects may well be large, if only because the number of procedural claims is so large. ${ }^{138}$ Peter Nardulli's famous study from the early 1980s showed suppression motions filed in $11 \%$ of felony cases. $^{139}$ Roughly contemporaneous data showed $9 \%$ of felony arrests that lead to indictment going to trial, and only $6 \%$ of felony arrests for which some charges are filed going to trial. ${ }^{1+0}$ If any significant portion of time spent on suppression motions otherwise would be spent on investigation, some of which presumably would lead to trials, abolition of the exclusionary rule would lead to a significant increase in the trial rate.

In short, constitutional law has gone some distance toward proceduralizing criminal litigation, and this proceduralization tends, at the margin, 10 reduce

\footnotetext{
136. Such claims tend to require a great deal of informstion both sbout hou other grind junes have been selected and about the demographics of the local population See, e g. Castaneda r Partuds. 430 U S 482, 486-88, 494-96 (1977).

137. Since Batson v Kentucky, 476 US 79 (1986), objections to the govemment's use ut pertmplury challenges require no more than what defense counsel knows trom situng in the courtroum when the relevant challenges were made. See $1 d$. at 96.

138. This is a controversial statement; the leading work on the empines of the exclusionary rute concludes that the number of claims is surprisingly small See Nardullt, supra nute 129. al 606 ("[l]t seems clear that the exclusionary rules .. have a truly marginal elfect on the cominal cuurt system ") As always, one's conclusion depends on one's baseline. Exclusionary rule litigatuon is rare in the sense that all criminal litigation is rare-the huge majonty of convictions are obiatned by guiliy ples, and in must of those cases there is, basically, no litigation al all For a discussion of one study that makes the punt nucely. see infra notes 141-144 and accompanying text. On the other hand, tf one compures the inculente of suppression motions to the incidence of enminal tnals, the former number looks yulte large Ser infra nutes 139-140 and accompanying text. Resource constrants place a very low celing on criminal lituguliun Within the fairly small universe of cases that generate claums of any son, procedural clasms, including exclustonary rule claims, loom large.

139. See Nardulli, supra note 129. at 593-94. Unusually hgh numbers from one jurisdiction may have distorted this figure; with that jurisdiction excluded the number was approximately $8 \%$-sull higher than the trial rate. See id. at 594. Nardulli's later study of exclusionary rule litugation in Chicago lound suppression motions filed in approxımately $10 \%$ of cases See Nardullt, supra note 128. A 228

140. See BOLAND ET AL., supra note 83, at 6.7 tbls 3. 4
} 
defense litigation of the merits. That claim is hard to prove (or disprove), but it does square with a variety of aspects of the current system. In their thorough study of appointed counsel in New York City, ${ }^{141}$ Michael McConville and Chester Mirsky found low levels of both factual investigation and motions practice. The levels were not, however, equally low. So-called "18-B Panel Attorneys," private lawyers assigned criminal cases, visited the crime scene in $12 \%$ of homicide cases ( $4 \%$ for other felonies) and interviewed witnesses in $21 \%$ of homicide cases and $4 \%$ of other felony cases. ${ }^{142}$ Use of experts was similarly rare, occurring in $17 \%$ of homicide cases and only $2 \%$ of other felony cases. ${ }^{143}$ Written motions were filed, meanwhile, in approximately $26 \%$ of homicide cases and $11 \%$ of other felony cases. ${ }^{144}$

The picture McConville and Mirsky paint is of a regime in which most cases receive almost no investment of attorney time and energy; resource constraints presumably make such an investment impossible. ${ }^{145}$ In the universe of cases in which attorneys do invest, pretrial motions practice leading to dismissal or negotiated settlement - the kind of process used for adjudicating almost all Fourth and Fifth Amendment claims and some Sixth and Fourteenth Amendment claims - is common. Homicide cases aside, factual investigation is exceptional. Even in homicide cases, motions practice seems to take precedence over factual inquiry. In a world in which defense attorney time is scarce, these activities must, to some degree, be substitutes for one another. And the greater the resource constraints placed on defense counsel, the higher the likely ratio between time spent on motions practice and time spent on investigation, because investigation is so much more expensive.

A parallel phenomenon exists in criminal appeals, as any scan of reported state court appellate decisions will show. Forty years ago, appellate opinions in criminal cases tended to focus on challenges to jury instructions and claims

141. McConville \& Mirsky, supra note 119.

142. See id. at 762 .

143. See id. at 764 .

144. See id. at 767.

145. McConville and Mirsky contend that resource constraints are part of a larger picture of nonadversarial criminal defense, with "those in control of indigent defense want[ing] low-cost, efficient processing of criminal defendants through guilty pleas and other non-trial dispositions." $/ d$. at 582 . This claim is similar to the hypothesis that appointed defense counsel function as case-processing burcaucrats closely allied to the prosecutors and courts, rather than as advocates for defendants-a hypothesis that used to be common in the social science literature but is now generally rejected. See, e.g., HANSON ET AL., supra note 22, at 66-69 (discussing and criticizing this view); MCINTYRE, supra note 22, at 46-49 (same).

The more plausible claim is that defense counsel do function as advocates, but only very selectively. because resource constraints make a more aggressive course impossible. Lisa McIntyre's excellent book on Chicago public defenders notes that the defenders see themselves as, and function as, adversarial litigants. See MCINTYRE, supra note 22, at 148-50. Yet McIntyre also notes that new public defenders receive essentially no training, apparently because caseloads make training impossible. See $i d$. at 102-04. (One lawyer described his early days in the public defender's office as follows: "I had a partner for one week and then I was put on my own. It was crazy, we used to do fifteen bench trials a cay and I had, on the average, forty clients a day." Id. at 103.) Finally, Mcintyre notes that defenders pushed clients to plead guilty with some frequency. See $i d$. at 154-56. These findings suggest that resources constrain litigation more than does any native disposition toward cooperation. 
that the proof of guilt was insufficient. Today, appellate opinions contain much less discussion of these sorts of claims; the dominant focus is on search and seizure, police interrogation, jury selection, and the like. ${ }^{\text {ts }}$ If reported decisions are a fair guide, appellate criminal litigation is criminal procedure litigation. Again, part of the reason is the cost advantage constitutional claims enjoy. That advantage extends beyond defense lawyers. Appellate judges can do a good job of deciding Fourth or Fifth Amendment claims by reading briefs. Sufficiency-of-the-evidence arguments are harder to evaluate. They require more familiarity with the record, which in turn requires a greater judicial investment in the case. This difficulty probably leads to greater judicial receptivity to legal claims than to factual ones (that cerainly seems consistent with the reported decisions), which only tends to reinforce defense attorneys' incentive to skew their investment in the direction of more constitutional litigation and less litigation about the facts.

Finally, a similar phenomenon may help to explain current perceptions of capital punishment litigation. Constitutional law has regulated such litigation extensively, and the regulation has focused almost exclusively on process. ${ }^{127}$ All this procedural Eighth Amendment law has generated a large number of claims, especially on appeal and habeas corpus, and the claims have been surprisingly successful-for a time, capital murder defendants enjoyed a more than fifty percent success rate in federal habeas corpus litigation. ${ }^{1+3}$ Yet in the face of all this procedural litigation, there remains a widespread distrust of the system's outcomes, a conviction that we are sentencing the wrong people to death. As Carol and Jordan Steiker have noted, ${ }^{149}$ this situation breeds two opposite criticisms of the current system of capital punishment: One side says the system is overregulated, that Eighth Amendment law is paralyzing (as shown by the volume of litigation and the long delays that attend executions). and the other says it is underregulated, that the law does not adequately guard against unfair outcomes (as shown by studies suggesting a bias against killers of white victims, ${ }^{150}$ and also by the disturbingly frequent Thin Blue Line-type cases $^{151}$ of convicted capital murder defendants subsequently shown to be probably innocent ${ }^{152}$ ). Steiker and Steiker contend that both sets of critics

146. I am aware of no systemauc study of this point. It rests unly on my own ubservalions from reading reported cases.

147. See Carol S. Steiker \& Jordan M. Steker. Sober Second Thoughts Reflechons on Two Decades of Constitutional Regulation of Capital Puntslment, 109 HARV L REV 355 parsin (1995)

148. See Donald P. Lay, The Writ of Habeas Corpus A Complex Procedure for a Simple Process, 77 MaN. L. REV. 1015, 1044 n.166 (1993) (collecung sources)

149. See Steiker \& Steiker, supra note 147, it 358.59

150. For the most famous study, see David Baldus el al. Comparanve Review of Death Sentences An Empirical Study of the Georgia Experience. $74 \mathrm{~J}$ CRIM L \& CRLMinolocr 601 (1983)

151. See THE THIN BLUE LNE (Miramax Films 1988) (documenting a case in which a defendant was convicted and sentenced to death notwithstanding substanual joubt about his guili)

152. See Hugh Adam Bedau \& Michael L. Radelet, Miscarriages of Justuce in Potentually Captal Cases, 40 STAN. L. REV. 21, 38 tbl.4 (1987) (finding 17 such cases in the 1970s and carly 1980s), see also EDWARD CONNORS ET AL., NATIONAL INST. OF JUSTICE. CUNVICTt.D BY JURIES. EXONE.RATED BY SCIENCE. 
have a point, largely because the Supreme Court has paid too little attention to regulating substantive outcomes. ${ }^{153}$

Steiker and Steiker have it right. But the problem goes deeper. It is not only that constitutional law has been too loath to regulate substance in the law of capital punishment. The point is that heavy procedural regulation has tended to drive substance away. In murder cases as elsewhere, arguments on the merits are costly, and the cost must be borne at the initial stages of the litigation: Witnesses must be interviewed and evidence must be marshalled if the argument is to be made at trial. Objections to things like the organization of the verdict form in the capital sentencing proceeding (a subject of heavy litigation that has spawned a significant body of law) $)^{154}$ are, by comparison, easy. So defense counsel operating under severe time and resource constraints may tend to substitute the latter for the former. The result is the seeming paradox we now have: a system with elaborate and carefully constructed procedures that cannot reliably generate sound results. Not only does more process not mean more accuracy, more process may actually mean less accuracy, because it encourages defense lawyers and courts to shift energy and attention away from the merits and toward procedure. In their desire to construct the best possible process for determining who must die, appellate courts may make the determinations worse.

In all three areas-trial litigation, appellate litigation, and capital murder litigation-the tradeoffs between constitutional litigation and other sorts of claims or arguments do not merely change the mix of claims a particular defendant raises. They also change which defendants aggressively contest the charges against them, meaning that they change the distribution of defense victories. Appointed defense counsel usually represent many criminal clients. Legal ethics doctrine treats these relationships as wholly distinct; decisions made in one case are not supposed to affect decisions made in others. ${ }^{155}$ But resource constraints make that impossible. Whatever ethical rules may say, lawyers must to some degree trade off claims and arguments across clients. A decision to take case $X$ to trial makes trial marginally less likely in case $Y$, simply because counsel cannot afford to try too many cases; rationing applies to the whole of counsel's caseload, not to any one case. The same thing is true

CASE STUdies IN THE USE OF DNA Evidence TO ESTABLISH INNOCENCE AFTER TRIAL 13-14 exh.2 (1996) (finding three cases of defendants sentenced to death and subsequently exonerated by DNA testing).

153. See Steiker \& Steiker, supra note 147, at 415-21.

154. The leading Supreme Court decisions are McKoy v. North Carolina, 494 U.S. 433 (1990); and Mills v. Maryland, 486 U.S. 367 (1988).

155. This follows from counsel's duty of loyalty, which is to the individual client, not to the class of counsel's clients taken as a whole. See generally 1 GEOFFrEY C. HAZARD, JR. \& W. WILLIAM HODES, THE LAW OF LAWYERING $§ 1.3: 106$ to :108 (2d ed. 1990 \& Supp. 1997) (discussing the formation of attorncyclient relationships in terms specific to individual clients). For a provocative article that explores the crossclient effects of public defenders' work, and how legal ethics should respond to those effects, see Kim Taylor-Thompson, Individual Actor v. Institutional Player: Alternating Visions of the Public Defender, 84 GEO. L.J. 2419 (1996). 
with suppression motions and self-defense claims, which do not necessarily arise in the same cases. More of the former must mean fewer of the latter, again because there is only so much time and it must be spread across so many cases.

None of this suggests that huge numbers of innocent defendants are incarcerated because of the law of criminal procedure. The dearth of factual investigation by appointed defense counsel is mostly the product of resource constraints. Even if Fourth and Fifth Amendment law were abolished, defense lawyers would find it impossible to do a thorough job of representing most of their clients. And the likelihood that innocents are being convicted may be lower than it was in the days when there was much less crime-a high ratio of crimes to prosecutors is the best protection for innocent defendants because it allows for more selectivity; it tends to keep prosecutors from casting their net too broadly. ${ }^{156}$ But criminal procedure probably does cause the system to do a poorer job of separating the guilty from the innocent than it otherwise would, holding resources constant. Constitutional law helps some defendants-and probably raises the overall level of defense victories-by giving their lawyers claims and arguments that otherwise would not exist. But those claims and arguments displace something. Some part, and quite possibly a large part, of what is displaced is attorney investigation and litigation of the merits. That harms defendants with marginal but colorable merits claims, claims that are less likely to be investigated and hence less likely ever to see the light of day.

\section{Reacting to the Defense: The Prosecution (Continued)}

Concern over the system's skill at separating the guilty from the innocent presupposes that the latter category exists. Not everyone accepts this premise. In a high-crime society in which police and prosecutors have many possible cases from which to choose, perhaps only the clearly guilty make it through the initial screening process. Perhaps Ed Meese's (in)famous claim that only the guilty are charged with crime ${ }^{157}$ was right.

This argument highlights an important and underrated feature of our current system: the degree to which the soring of defendants is done by prosecutors rather than by judges and juries. One-fifth of felony arrestees in state cases are never charged; another fifth are not convicted, and still another fifth are never incarcerated (meaning, for the most part, they received favorable

156. For the same reason, prosecutors' view of what constututes a sufficiently senous oflense to justufy criminal intervention is likely to change with crime rates. $C f$ Austun \& Knsterg. supra note 93, at 177 (discussing the tendency of criminal justıce "insıders" to suppor decrnminalizang marginal uffenses)

157. Actually, Meese's claim was more extreme: that only the guilly dre suspects See Marc Miller \& Martin Guggenheim, Pretrial Detention and Punslunent, 75 MINN L REV 335. +14 n +19 (1990) 
charging decisions). ${ }^{158}$ In a system with those kinds of numbers, the prosecutor represents the best shot any defendant, guilty or innocent, has at a favorable outcome. So the prosecutor's incentive to screen cases well, to separate those who are clearly guilty from those who are not, is key to the system's success at separating those categories. That incentive, in turn, depends on the litigation that takes place in contested cases. Criminal litigation is the price prosecutors pay for charging errors. The nature of that price, and when it is paid, helps determine who will be charged with what. ${ }^{159}$

That is the real answer to the claim that innocents probably do not exist in sufficient numbers to be worth worrying about. The claim is likely to be correct only in a system in which prosecutors screen well. But prosecutors are likely to screen well only if criminal litigation encourages them to do so; otherwise, successful sorting of criminal defendants depends on nothing more than prosecutorial good will.

And criminal procedure diminishes this incentive to screen well; or, to be more precise, it encourages prosecutors to screen differently than they otherwise would. In the criminal process, the presence of plausible constitutional claims is a poor proxy for plausible claims on the merits. Discriminatory jury selection may lead to biased juries, which then do a bad job of deciding whether the defendant is guilty. Yet there is no good reason to treat any particular instance of discriminatory jury selection as a signal that this jury erred in finding this defendant guilty; a much better way to identify likely errors would be to look at the evidence in particular cases. A great many

158. See 1991 SOURCEBOOK, supra note 10, at 546 tbl.5.53 (reporting the results of a study of felony arrests in eight states showing that $81 \%$ of arrestees are prosecuted, $59 \%$ are convicted, and $39 \%$ are incarcerated).

159. This idea-that decisions not to litigate are made against the backdrop of legal rules that would govern litigation if it happened-is commonplace in discussions of civil settements. Curiously, it is not such a common idea in the literature on prosecutors. That literature has done little to address the question of why prosecutors charge in some cases rather than in others. The most thorough descriptive work, FRANK W. Miller, Prosecution: The Decision To Charge a SusPeCt WITH A CRIME (1969), cmphasizes both resource constraints and prosecutors' substantive goals, but offers no approach to predicting outcomes when these factors point in different directions.

Discussion of prosecutorial incentives is fairly advanced in analyses of the effects of the federal sentencing guidelines, see Jeffrey Standen, Plea Bargaining in the Shadow of the Guidelines, 81 CAL. L. REV. 1471 (1993), and of successive prosecution, see Danicl C. Richman, Bargaining About Future Jeopardy, 49 VAND. L. REV. 1181 (1996), but elsewhere we have not advanced beyond the proposition that prosecutors are generally interested in both high conviction rates and the avoidance of unnecessary work, see Stephen J. Schulhofer, Criminal Justice Discretion as a Regulatory System, 17 J. LEGAL STUD. 43, 50. 52 (1988). The first of these goals follows from prosecutors' political status-most district attorneys' offices are headed by an elected official. See Daniel C. Richman, Old Chief v. United States: Stipulating Away Prosecutorial Accountability?, 83 VA. L. REV. 939 (1997) (explaining connections among electoril accountability, litigation incentives, and conviction rates). The second goal follows from prosecutors' payment mechanism: They are paid on salary, not by the case.

For purposes of my argument, I assume that, whatever else prosecutors are secking to do (and there is no doubt a good deal else), they are indeed seeking to maintain high conviction rates and to avoid needless labor, as Schulhofer suggests. That is, I assume prosecutors prefer winning to losing, and prefer less litigation to more. Both preferences push prosecutors, where possible, to substitute cases likcly to generate little or no litigation for cases likely to generate a lot. The content of the latter category depends, in turn, on what sons of claims, and what sorts of cases, are litigated. 
criminal procedure claims are like that: They correlate (if at all) only very slightly with strong claims on the merits.

For much of criminal procedure, the correlation is actually negative: Defendants with strong constitutional claims are more likely to be guilty than defendants as a whole. This is obviously true of search and seizure law, which is invoked in criminal proceedings only when there is incriminating evidence to suppress. It is very likely true of Miranda doctrine as well, since that doctrine requires the suppression of incriminating statements and since most Miranda violations probably have little to do with the reliability of the statements being suppressed. ${ }^{160}$ For these sorts of claims, defense litigation not only fails to advance separation of the guilty from the innocent, it actually retards the system's ability to separate. Defense lawyers shifting time and energy from factual investigation to criminal procedure litigation are probably shifting time and energy from one set of defendants to another, and the losers in this shift are likely to be defendants with colorable but undiscovered factual arguments.

This shift may be fairly small, but its effects are magnified by prosecutors. If defense litigation is skewed toward some claims and away from others, prosecutors' incentive to screen cases will be skewed in the same way. The effect that matters most may not be the change in defense attomey litigation, but the ancillary change in prosecutors' charging decisions.

An extreme example should make the point. ${ }^{161}$ Imagine two jurisdictions, one with very pro-defendant procedural doctrines that seem to help innocent

160. The core of Miranda is its bar on police-initiated internogation after a suspeat has invoked his right to counsel. See William J Stuntz, Waning Rights in Crimmal Procedure. 75 VA L REV 761. 818.22 (1989); supra notes 61-63. Recent empirical work suggests that (the overwhelming mujority of invocittuns of the right to counsel occur shorly after arrest, not after extended questuoning See Puul G Cussell \& Bret S. Hayman, Police Interrogation in the 1990s: An Emprical Srudv of the Effects of Mirands. +3 UCLA L REV. 839, 859-61 (1996); Richard A. Leo, The Impact of Miranda Revistied. 86 J CkiM L. \& CRIMINOLOGY 621, 653 (1996). In other work, Cassell has also shown that the duminant eflect of Meranda stems not from the famous warnings but from the bar on post-invocstion questioning by the police See Paul G. Cassell, Miranda's Social Costs: An Empirical Reassessmen. 90 NW U L REY 387.492 .96 (1996). It follows that violations of the bar on post-invocition questuoning. which probably constitute the majority of Miranda violations, are unlikely to involve the kind of pressure thal would lead innucent defendants to confess. Such violations are more lakely to take the form of routune polite questioning at a time when questioning is forbidden.

Ironically, cases that may involve the kind of cocretion that would lead innocents tu contess may nut raise Miranda violations in the first place, because once Miranda wamngs are given and the suspect agrees to talk, courts seem to indulge a strong presumption that any statement that folluws is voluntary See Luuts Michael Seidman, Brown and Miranda, 80 CAL L REv 673. 744-16 (1992) Peter Arenella nutes that homicide interrogations tend to last a good deal longer than anterrogations for uther ullenses See Peter Arenella, Miranda Srories, 20 HARV. J.L. \& PUB POL'Y 375. 379 n 25 (1997) (culung David StMos: HOMICIDE: A YEAR ON THE KILLING STREETS 206 (1991)) These are precisely the sun uf cises in which suspects may become confused or worn down, leading to contessions that are not necessunly reliable Miranda's focus on the warnings rather than the interrogation process provides litle protection against errors in such cases. Thus it is possible that Miranda makes it both harder to get conlessions from the guilty and easier to get them from the innocent

161. This argument is developed at greater length in Willam J Stunu, Luwyers, Deception. and Evidence Gathering, 79 VA. L. REV. 1903, 1929-34 (1993) 
and guilty defendants alike, the other with few such doctrines. In the jurisdiction with very pro-defendant doctrine, innocent defendants, on average, face a $25 \%$ chance of conviction once charged; for guilty defendants, the average is $40 \%$. Odds vary in particular cases. In the more hard-line jurisdiction, the average chance of conviction for innocent defendants is $40 \%$, while the average for guilty defendants is $90 \%$. In neither jurisdiction do prosecutors know who is guilty and who is innocent. To prosecutors, all defendants look (very probably) guilty. But prosecutors can do a decent job of estimating the odds, ex ante, that the defendant will win. ${ }^{162}$ Finally, assume that both jurisdictions have high ratios of crimes to prosecutors: Many cases must be dismissed and many others must be bargained down, because there is not enough time to pursue all plausible charges. Which jurisdiction would innocent suspects prefer?

If prosecutors filed charges in all plausible cases, the answer would be clear: Innocents would prefer the first, more pro-defendant jurisdiction, because a defense victory would be more likely there. But given a high crime-toprosecutor ratio, meaning a good deal of selectivity in charging, innocents are better off in the second jurisdiction. In the first, more pro-defendant jurisdiction, prosecutors lose little by guessing wrong about defendants' innocence or guilt, because the odds of convicting the guilty are not vastly higher than the odds of convicting the innocent. Mistaking a probable loss for a slightly more probable loss is, from the prosecutor's point of view, a shame but hardly a disaster. And, of course, in any system where defense victories are so common, any given defense victory would tend not to be terribly salient-the fear of losing is much higher when losing is a rare event than when it is the norm.

In the second jurisdiction, on the other hand, prosecutorial misjudgments about innocence and guilt (or about the odds of conviction, which correlate strongly with innocence and guilt) are much more costly. A prosecutor who mistakes a " $40 \%$ case" for a " $90 \%$ case" has substituted a likely loser for an almost-sure winner. If there are many such mistakes, the prosecutor significantly lowers her success rate, for which she pays a political price. And in a world filled with "90\% cases," individual government losses will tend to

162. It may seem contradictory to suppose that (1) on average, innocent delendants have a much better chance of prevailing at trial than guilty ones; (2) prosecutors do a reasonably good job of estimating defendants' odds of conviction at trial; and (3) prosecutors believe all defendants are guilty. Yet all three propositions are very probably true of the existing system. (The only doubtful point is the first one: As no one knows how many innocent defendants there are, no one knows how well they fare at trial. Still, if the trial process accomplishes anything at all, it must be that innocents win a disproportionate share of acquittals.) The seeming contradiction disappears on either of two grounds. First, prosecutors do not know the average odds of acquittal for guilty and innocent defendants; they know only the odds for individual defendants. Second, the averages are just that-averages. In the hypothetical in the text as in life, guilty defendants are usually easy to convict but not always; innocent defendants often have strong cases but sometimes not. That being so, prosecutors could fairly easily convince themselves that a given defendant is guilty notwithstanding that he has a good chance of victory if the case goes to trial. 
be salient, at least relative to a world where defendants win much more often. Finally, of course, if prosecutors must be selective, they do not have the option of taking all the clear winners and then picking from among the likely losers; every losing case the prosecutor pursues represents a winner (probably several winners, given the greater ease with which $90 \%$ cases can be turned into guilty pleas) that was passed up. These costs encourage prosecutors to avoid charging the $40 \%$ cases. That helps innocent defendants-indeed, it helps them more than anything else the system does, for it prevents them from becoming defendants in the first place.

Now consider the lesson from this stylized example. In a high-crime, highdiscretion system, innocent defendants should probably care more about the gap between their own chances at trial and the chances of guilty defendants than about their chances of success in absolute terms. The size of the gap determines prosecutors' incentive to pay close attention to strong and weak cases, to do a good job of deciding who is plainly guilty and who might not be. And, as a practical matter, prosecutors decide most cases. Criminal procedure litigation tends to narrow the gap between the odds of convicting the guilty and the odds of convicting the innocent, because it bestows its victories either indiscriminately (innocent and guilty defendants alike might be indicted by improperly selected grand juries) or perversely (only the guilty are likely to have strong Fourth Amendment claims). It thereby reduces prosecutors' incentive to separate the guilty from the innocent at the charging stage.

Like other litigators, prosecutors prefer winning to losing. Like other bureaucrats, they also prefer cheap matters to expensive ones. Both preferences push prosecutors to screen cases according to the way (and the likelihood that) those cases will be litigated if charged. The more criminal litigation focuses on procedure, the bigger the incentive for prosecutors to screen cases with procedure in mind. The less criminal litigation focuses on the mertis, the smaller the incentive for prosecutors to make sure they are charging only in strong cases-which is to say, the smaller the incentive to charge only guilty defendants.

\section{Distribution, Discretion, and Discrimination}

Given the way the criminal justice system is presently organızed, defendants' rights have complicated, and to some degree perverse, distributive consequences. Those consequences are, in turn, tied closely to the discretıonary nature of the relevant decisions. Prosecutors are free to steer therr charging decisions in one direction or another. Defense counsel are free to steer their litigation toward some claims rather than others. Legislatures are free to fund criminal defense generously or not. And, of course, legislatures can define substantive criminal law broadly or narrowly. The law of criminal procedure 
alters the calculus of these decisions in some harmful ways, without changing the power of the people who make them.

That suggests an important constraint on the law of criminal procedure-something it probably cannot do, at least in its current form. It cannot stop discrimination. According to the conventional understanding, much of the reason for the criminal procedure revolution of the 1960s was the need to rein in a discriminatory criminal justice system, to keep police and prosecutors from victimizing, not just criminal defendants in general, but black defendants in particular. ${ }^{163}$ Defendants' rights were to serve as the reins. But defendants' rights address only one form of discrimination, and it is probably the least important form that the system engages in. Because of Fourth, Fifth, and Sixth Amendment law, the system cannot give jury trials or lawyers to white defendants but not to black ones, and the police cannot use search warrants only when searching Latino suspects' houses. Constitutional standards prevent discrimination that takes the form of violating those very standards. But constitutional law has little to say about the decisions that are most likely to be made discriminatorily, because constitutional law leaves intact a high level of discretion on the part of legislatures, prosecutors, police officers, and defense attorneys. Selection of suspects or defendants-charging black drug dealers more readily than white ones-is basically unregulated. ${ }^{164}$ The manner in which suspects are arrested-how much force the police use, and whether they tend to use more force on some kinds of suspects than others-is regulated only slightly, because police violence tends not to be tied to police evidence gathering, and only evidence gathering is likely to give rise to exclusionary rule claims. ${ }^{165}$ Most importantly, the definition of crimes and the fixing of sentences is constitutionally unregulated, meaning that the law of criminal procedure leaves legislatures free to adopt drug and sentencing policies that lead to massive increases in the proportion of black prisoners-as

163. See supra note 4 and accompanying text. For a good discussion of this point and its relevance to originalist arguments in criminal procedure generally and the debate about the exclusionary rule in particular, see Steiker, supra note 3, at 838-52.

164. McCleskey v. Kemp, 481 U.S. 279 (1987), shows how hard it is to make out a claim of discriminatory prosecution, since the substantial race-of-the-victim bias shown in that case did not suffice. McCleskey, a black man convicted of killing a white man, relied on a study that showed, inter alia, that the death penalty was imposed in $22 \%$ of cases with black perpetrators and white victims, $8 \%$ of cases with white perpetrators and white victims, $3 \%$ of cases with white perpetrators and black victims, and only $1 \%$ of cases with black perpetrators and black victims. See id. at 286. The Court rejected McCleskey's equal protection claim on the ground that his data did not establish any intentional discrimination in his casc. See id. at 292-97. United States v. Armstrong, $116 \mathrm{~S}$. Ct. 1480 (1996), shows how hard it is even to trigger discovery obligations, so that claimants might obtain the information they need to meet the standard McCleskey sets. In Armstrong, the claimants proffered evidence that the pool of federal crack defendants in the relevant district was entirely black. The Supreme Court held that the claimants had to prove the existence of cases involving white suspects that might have been charged but were not. See id. at 1483-84. 1488-89.

165. This point is elaborated in William J. Stuntz, Privacy's Problem and the Law of Criminal Procedure, 93 MICH. L. REV. 1016, 1060-68 (1995). 
legislatures have done. ${ }^{166}$ If one is looking for race discrimination in the administration of criminal justice, these are the places to find it. And the law of criminal procedure has almost nothing to say about them.

Indeed, that law raises the potential for discrimination, or at least the potential for policies with a racially disparate impact. If poor defendants are disproportionately black, ${ }^{167}$ the law of criminal procedure not only makes the universe of defendants poorer, but blacker as well. Similarly, steering litigation away from factual innocence claims may have a race effect, because black defendants may have a disproportionate share of plausible-but-not-ironclad claims: Consider the strong evidence that cross-racial eyewitness identifications are worth vastly less than juries tend to believe, ${ }^{108}$ and note that black-onwhite crime vastly exceeds the white-on-black variety ${ }^{169}$ (so that cross-racial identifications will tend to victimize black defendants much more often than white ones).

And criminal procedure raises the cost of pursuing some sorts of crime more than others. Fourth Amendment law makes drug investigations somewhat costlier, because it forbids most sweeps, blanket searches, and suspicionless street stops. ${ }^{170}$ This may have played some par in legislatures' decisions to ratchet up drug sentences over the past generation: The costlier it is to catch offenders, the more important it is to punish them severely when caught. ${ }^{171}$

166. For an excellent discussion of this phenomenon as 11 applics to federal sentencing of crack and cocaine powder defendants, see David A. Sklansky, Cocaune, Race, and Equal Protechon, 47 STdx L. REV. 1283 (1995). For an equally good discussion that covers drug and sentencing policy more generally. see Michael Tonry, Malign Neglect-RaCe, Crime. AND PUNishment w Aliekica (1995)

167. They almost certainly are. Defendants as a whole are disproportionately black See, e $g$. Developments in the Law-Race and the Crunmal Proccss. 101 HakV L REV 1472. 1525.28 (1988) (citing sources). Defendants as a whole are also dispropontionately poor Eighty percent of them receive appointed counsel. See Smith \& DeFrances, supra note 7. dt \& Finally. white collar defendants, a substantial slice of the universe of defendants with money. are much more often white than defendants as a whole and slightly whiter than the general population See WEISBUKI) FT AL, supra nute 101. al 70

168. See Sheri Lynn Johnson, Cross-Racial denuficanon Errors in Crumual Cases. 69 CokNell L REV. 934, 937-38 (1984).

169. The gap is best established for murder According to the FB1. 1924 sall 790 blatk-on-white murders and 337 white-on-black murders. See FBI, UNItoks CRIMt RtPOkTS. CRLMt W nit (NITt) STATES 1994, at 17 tbl.2.8 (1995).

170. Delaware v: Prouse, 440 U.S. 648 (1979), forbids suspicionless stops of autumubules, Ybarra 、 Illinois, 444 U.S. 85 (1979), and Terny : Oho. 392 U S 1 (1968), stund tor the sime proposition for individuals. Group seizures are, for now, permissible only in the context of drunk dnving roadblocks, see Michigan Dep't of State Police v. Sitz, 496 U.S. 444, 451-55 (1990), though that ealtegory may grow Even if a brief seizure is justifiable, under current law the police may not search absent either consent or reasonable suspicion that weapons are present-suspicton that drugs muy be present does nut sutfice See Sibron v. New York, 392 U.S. 40 (1968); Tern: 392 U S at 24-27

171. For a rare acknowledgment of this connection between criminal procedure and sententing polity. see William T. Pizzi, Punislument and Procedure: A Differen View of the Anterican Crumunal Justice System, 13 CONST. COMMENTARY 55.65-69 (1996). As Piza nghtly notes, the connectuon runs both ways "Harsh punishments in tum encourage even more emphasis on procedure." als cours seck to protect defendants from the consequences of legislatuve seventy. Id at 67

For another example of more expensive process producing higher sentences, see RosteNBtRO. supra note 94 , at 314-16, which notes that, after juvenile defendants were afforded the nght to counsel. sentences of juveniles using lawyers were higher than sentences of uncounseled juvenules 
As Michael Tonry and others have noted, the rise in severity of drug sentences has dramatically increased the proportion of blacks in prison. ${ }^{172}$ Of course, other factors entered into those sentencing policies; Fourth Amendment law was not the sole or even primary cause. But Fourth Amendment law did make those policies marginally more attractive and hence, perhaps, marginally more extreme.

The point is that constitutional criminal procedure not only carries some perverse distributive consequences; it also fails in the task that, more than anything else, prompted its design. The reason is that the law of criminal procedure is part of a larger system in which a variety of actors have a great deal of freedom of movement. Those actors respond to the law; they also respond to other forces outside the law, to crime rates and caseloads and funding levels. The combined effect of these forces is complicated. Any fair evaluation involves a good deal of guesswork. Still, two propositions seem fairly clear. First, defendants' rights do not live up to their billing: Resource constraints make constitutional enforcement spotty, and constitutional law leaves discrimination almost untouched. Second, defendants' rights advantage some defendants at the cost of disadvantaging others, and the selection of winners and losers does not do the system credit.

\section{Defining CRiminal Procedure}

Why is it so hard to protect the interests criminal procedure protects without disadvantaging the poor and the innocent, at least marginally, relative to the rich and the guilty? One answer, as I have tried to suggest, lies in crime rates and resource decisions that might change over time. Indeed, they already have-crime rates are falling, dramatically in some places. ${ }^{173}$ Resources may continue to rise. The problems that produce these perverse distributive effects are probably less severe now than they were five years ago. Perhaps they will be less severe still five years from now. On this view, the perverse dynamics of the criminal process may not be worth worrying about.

172. For the best discussions, see TONRY, supra note 166, at 81-83, 104-115; and Sklansky, supra notc 166 , at 1283-90.

173. On the recent nationwide drop in crime rates, see, for example, Fox Butterfield, Large Drop in Violent Crime Is Reported, N.Y. TMES, Sept. 18, 1996, at A14. On the more dramatic drop in New York City's crime rate, see Clifford Krauss, New York Crime Rate Plummets to Levels Not Seen in 30 Years, N.Y. TIMES, Dec. 20, 1996, at A1.

The decline in serious crime does not necessarily equal a decline in prosecutors' dockets. One approach to crime control that has achieved a great deal of popularity of late is to raise sharply the level of prosecution for low-level street offenses such as vandalism, as a means of signaling a commitment to public order. See generally GEORGE L. KELLING \& CATHERINE M. COLES, FIXINO BRoKEN WINDOWS: RESTORING ORDER AND REDUCING CRIME IN OUR COMMUNITIES (1996) (advocating this approach). That can lead to an increase in case pressure, even if the strategy is successful in lowering crime rates. See Clyde Haberman, Crime Down, But Courts Are Clogged, N.Y. TMES, Jan. 3, 1997, at BI (reporting this effect). 
Another answer is less pleasant. The most fundamental structural feature of rights in the criminal process is that appellate courts define them. Almost no one argues with this regime; the constitutionalization of criminal procedure, in a society in which judges define constitutional law, today goes unchallenged. That is a serious mistake, for the current allocation of authonty between courts and legislatures encourages each side to undermine the other. The problem with the criminal process may not be particular rules or practices, but rather the system that defines what that process should look like.

\section{A. The Structure of the System}

A growing body of literature argues that constitutional law is a lot more majoritarian-even measuring majoritarian preferences over the short-tomedium term-than we tend to think. ${ }^{174}$ However well this argument may describe constitutional law generally, it plainly does not fit criminal procedure. Fourth, Fifth, and Sixth Amendment law is nothing if not countermajoritarian. No legislature has passed anything like Miranda. On the contrary, the only legislative response to that decision was a congressional effort to overrule it. ${ }^{175}$ The same is generally true of Mapp 1 : Ohio's imposition of the exclusionary rule, ${ }^{176}$ the law defining effective assistance of counsel, most of double jeopardy doctrine, the several bodies of law that regulate jury selection-indeed, almost everything in the law of constitutional criminal procedure. ${ }^{177}$ Elsewhere, constitutional law may be in the habit of adopting standards that at least some political majorities have adopted for themselves. In criminal procedure, the strong pattern is to impose standards on the federal and state governments that those governments would not have imposed on themselves, and for which the population at large would not vote if given the chance. ${ }^{178}$

174. The argument has been most thoroughly developed by Michacl Klaman Sec Mlichael J Klarman. Rethinking the Civil Rights and Cisl Liberties Reiolutions. 82 VA L REV 1 (1\%\%) For two vanultuns on the theme, see ROSENBERG, supra note 94, which denies courts abilities to engender countermajoritansan social reform, and Barry Friedman, Dialogue and Judecul Reverw. 91 MicH L REV 577 (1993), which treats judicial review as part of a majontanan dialoguc with legislitures

175. See 18 U.S.C. \$ 3501 (1994) (making confessions admissible in any federal cruminal procerding if voluntarily given and investing trial judges with the discretion to determune any tssues ds to voluntariness).

176. 367 U.S. $643(1961)$.

177. The only major exceptions are the existence of \& broad nght to jury ind. which was well enshrined before the Supreme Cour required it in Duncan y. Lousiara, 391 U S 1.5 (1968). and the nght to appointed counsel for indigent defendants, which most states already provided, after a fushuon, when the Coun decided Gideon v. Wainwright, 372 U.S. 335 (1963)

178. To be sure, legislatures could overum some cnminal procedure doctnnes Both bapp and Miranda are now deemed to be not quite constitutionally required rules subject to legislative revision See. e.g., United States v. Leon, 468 U.S. 897. 906-07 (1984) (holding that the exclustonary rule is not constitutionally required); New York v. Quarles, 467 U.S 649.654 (1984) (holding the same for bturanda) Even for doctrines in that category, however, legislatuve overruling is extremely nsky Cuurts could conclude that the regime substituted for the overtumed criminal procedure doctnne is nut an adequate replacement. And under current retroactivity doctrines. that would place at nsk every cominal conviction 
Not surprisingly, this state of affairs leads to a fair amount of concern with judicial overreaching. The court system has not ignored that concern. On the contrary, it is probably a large part of why courts (the Supreme Court in particular) have limited the sphere of judicial intervention in the criminal justice system-why they have placed constitutional law securely in the confines of the criminal process. Constitutionally speaking, substantive criminal law is almost entirely unregulated. ${ }^{179}$ And as is generally true elsewhere in constitutional law, resource allocation, the funding of the system, is left to the politicians.

So the law of constitutional criminal procedure conforms to a classic constitutional model. It is plainly, even aggressively, countermajoritarian within its sphere, but the sphere is carefully limited. In good Hart and Sacks fashion, ${ }^{180}$ the law focuses on process rather than substance, and it seeks to avoid directing government taxing and spending decisions. Note the familiar combination of judicial aggressiveness on procedure, the sort of thing courts are supposed to be good at, with deference to political majorities on substance and funding, issues that seem more political and value-laden. It is not only a familiar structure, but a profoundly conservative one. Perhaps that is why the character of constitutional law in this area is so rarely contested in the cases or literature. The system seems to exhibit a sense of balance, at once protecting minorities and leaving room for majorities to govern as they wish.

Yet given the dynamic outlined in Part II, this system is less a careful balance than a vicious circle. Countermajoritarian criminal procedure tends to encourage legislatures to pass overbroad criminal statutes and to underfund defense counsel. These actions in turn tend to mask the costs of procedural rules, thereby encouraging courts to make more such rules. That raises legislatures' incentive to overcriminalize and underfund. So the circle goes. This is a necessary consequence of a system with extensive, judicially defined regulation of the criminal process, coupled with extensive legislative authority over everything else.

There is another consequence of this structure. The system may well need something that neither legislatures nor courts can provide: It may need, not more money for criminal defense or less constitutional regulation of the process, but both at the same time. More money without less law might only make for more procedural litigation. Less law without more money would not

in the trial and appellate pipelines in which evidence obtained under the new regime had been used. See Griffith v. Kentucky, 479 U.S. 314 (1987) (holding that new rules are to be applied retroactively on direct review). The magnitude of this risk explains why no state has undertaken any serious effort to experiment with altematives to Mapp and Miranda. And, of course, the risk is even greater for rules that are, at least nominally, constitutionally required: There, any legislative alteration is presumptively impermissible.

179. For an elaboration of this point and its consequences, see Stuntz, supra note 5. See also infra Part IV.

180. See Henry M. Hart, Jr. \& Albert M. Sacks, The Legal Process (William N. Eskridge, Jr. \& Philip P. Frickey eds., 1994). 
address the resource constraints that so severely limit attomey investigation. But since courts control the law and legislatures control the money, changing both at the same time in the right directions is impossible. Instead, the current regime encourages change in the wrong directions: Overregulation and underfunding feed on each other.

\section{B. Legislatures' Incentives}

Consider first the legislative half of this dynamic. Legislatures presumably fund enterprises more or less generously according to some mix of their political and social value (measuring the latter by legislators' lights, not by courts'). The more criminal defense counsel litigate claims of which legislatures disapprove-the more counsel serve as watchdogs for rights legislatures did not enact and do not like-the less funding counsel can be expected to receive, all else being equal. ${ }^{181}$

The natural consequence is constrained funding for criminal defense. Overall funding for criminal defense has declined on a per case basis since the late $1970 \mathrm{~s}^{182}$ a period in which the law of criminal procedure mushroomed-which ought to have raised litigation costs. And, of course, there is a good deal of anecdotal evidence that funding for criminal defense is very low in absolute terms, that public defenders in many jurisdictions must cope with mind-boggling caseloads. ${ }^{183}$ Finally, in some jurisdictions criminal defense spending has actually been cut-not just per case spending, but total

181. One sees this dynamic most starkly in recent congressional efforts to rein in the Legal Services Corporation. See Omnibus Consolidated Rescissions and Appropnatsons Act of 1996. Pub L No 104-134. 110 Stat. 1321 [hereinafter OCRAA]. Congress cut funding for legal services not primanly to save money. but because of "the conviction of many Republicans in Congress that legal and lawyers promote a left-wing agenda through lobbying and litigation." Robert Pear, As Welfare Osertiaul Looms, Legal Aid for Puor Dwindles, N.Y. TMES, Sept. 5, 1995, at Al.

The cuts in legal aid went beyond funding: most famousiy. Congress barred the filung of class actions by federally funded legal services agencies. See OCRAA $\$ 504(a)(7)$. This resinction is already running into problems in the courts, however. See Don Van Natu, Jr. Legal Senices Wins on Sun for the Poor, N.Y. TMMES, Dec. 27, 1996, at B1 (reporting on a stalc cour decision that the class betion ban is unconstitutional); see also Recent Legislation, Constututhonal Law-Congress Imposes New Restrtctons on Use of Funds by the Legal Senices Corporation, $110 \mathrm{HAkV}$ L REV 1346 (1997) (arguing thal the restrictions are unconstitutional). Even if a similar approach to cnminal defense-secking to reın in some claims but not others-were administratuvely possible. It would plannly be constitutionally suspect. given the constitutional status of the relevant clams.

182. See supra notes $16-19$ and accompanying text

183. See, e.g., KLEIN \& SPANGENBERG, supra nole 20, al 1-4, supra noles $20-22$ and accompanying text.

The surprise is that funding for criminal defense has been treated as well as $t$ has As a proportion of total state and local budgets for criminal jusuce, cnminal defense actually grew between 1979 and 1990 - defense budgets rose $274 \%$ during that penod, as comparod to an overall nse in criminal justuce budgets of $187 \%$ (one must keep in mind that these are non-inllation-adjusted dollars) See 1993 SOURCEBOOK, supra note 8 , at 3 tbl.1.3. Yel these figures must be read aganst the backdrop of nsing caseloads, including a steep rise in the proportion of cases in which defendants receive appointed counsel See supra notes 7,11-32 and accompanying text 
spending. ${ }^{184}$ Spending cuts for prosecution and the court system are unknown.

The standard politician's gripe about defendants winning on "technicalities" suggests that constitutional law has played some role in these developments. That would be quite natural. From the politicians' perspective, the law of criminal procedure has reduced the benefit of the marginal dollar of defense funding, because it ensures that a substantial part of that dollar will be spent in ways legislators do not want. The logical result is less money for defense than in a world with fewer of the hated "technicalities." The law of criminal procedure thus may give defense counsel more arguments to raise-more arrows in the quiver - but at the cost of also giving them less time and money to work with-fewer shots at the target.

Given the tendency of legal claims and arguments to drive out factual ones (because the former are cheaper to evaluate and litigate than the latter), this dynamic is self-reinforcing. Lower funding of criminal defense reduces all sorts of defense litigation, but the reduction may not be evenly distributed. Factual litigation probably suffers more-as resource constraints become more severe, procedural litigation's cost advantage becomes more compelling. The result is likely to be a system where litigation is more concentrated on procedural issues. The sense that technicalities dominate the system thus is bound to grow even as legislatures seek to combat those very technicalities.

A similar dynamic is at work for wealthy criminal defendants, though here the dominant legislative lever is not money but substantive law. Recall that criminal procedure tends to raise the cost of criminal prosecution, but does not do so evenly. Rather, it tends to raise the relative cost of prosecuting defendants with money, who can best afford to litigate aggressively. One result, as I suggested in Part II, is to encourage federal rather than local prosecution of such defendants. Another result is to drive Congress to broaden the definition of crimes (and raise sentences, which has much the same effect as more broadly defined crimes) that better-off defendants commit. By defining crimes more broadly, legislatures make proof of guilt easier, which converts otherwise contestable cases into guilty pleas, thereby avoiding most of the costs criminal procedure creates. ${ }^{185}$ The same, to some degree, is true of higher mandatory sentences, which raise the risk to defendants of taking their cases to trial and thus once again tend to convert otherwise contested cases into guilty pleas. ${ }^{186}$

184. For examples, see Robert L. Spangenberg \& Tessa J. Schwartz, The Indigent Defense Crisis is Chronic, CRIM. JUST., Summer 1994, at 13-14; and Taylor-Thompson, supra note 155, at 2431 \& n.59. The Chief Justice of the Louisiana Supreme Court has noted that his state's spending on indigent defense was cut during the late 1980 s while the caseload was undergoing a $45 \%$ increase. See Pascal F. Calogero, Jr., The State of Indigent Defense in Louisiana, 42 LA. B.J. 454, 456-57 (1995).

185. See Stuntz, supra note 5, at 7-19.

186. For an elaboration, see Scott \& Stuntz, supra note 135, at 1960-66. 
One sees this effect in several areas of federal criminal law that tend to involve a heavy proportion of wealthy defendants. Prosecuting organized crime used to mean proving conspiracy. RICO does away with proof of agreement, ${ }^{187}$ and also ratchets up penalties. ${ }^{188}$ Forfeiture laws make it much easier for the government to tie up defendants' resources based on a showing that those resources were probably (not beyond a reasonable doubt) the product of a criminal enterprise, ${ }^{189}$ which obviously helps prosecutors to neutralize the wealth advantage of major drug dealers. And the sharp rise in drug sentences since the early 1980s has made it possible to use possession or possession with intent to distribute, which are more easily proved than distribution and conspiracy to distribute, as proxies for those more serious offenses. ${ }^{190}$

The most striking example is the range of federal statutes that cover white collar crime-mail and wire fraud, securities fraud, currency and banking offenses, and so forth. The number of such statutes has grown substantially in the past thirty years, and a number of older offenses (including mail and wire fraud, which are probably the most important ones) have been legislatively broadened. ${ }^{191}$ The upshot is that white collar offenses, unlike traditional street crimes such as burglary, robbery, or homicide, cover a vast range of conduct that neither Congress nor prosecutors could plausibly wish to punish. Mail and wire fraud include deprivations of so-called "intangible rights," meaning that tangible injury need not be proved. (It also means that federal fraud offenses extend to cases of low-level influence peddling that involve no overt dishonesty.) $)^{193}$ Currency fraud includes not only the intentional

187. That is, RICO effectively broadens the scope of conspiricy liabulity by substututing cruminal enterprises for criminal agreements. See Gerard E. Lynch, RICO: The Crume of Besng a Crumumal (pis. 3 \& 4), 87 COLUM. L. REV. 920, 945-55 (1987); see also Racketeenng Inlluenced and Corrupt Organizations (RICO) Act, 18 U.S.C. \$§ 1961-1968 (1994).

188. See Lynch, supra note 187 , at $924-28$.

189. See, e.g., 21 U.S.C. $\S 853(\mathrm{c})(1)(\mathrm{A})$ (1994) (permutung the government to freeze assets upon the filing of an indictment or information charging a qualıfyıng cnme)

190. Between 1982 and 1992, the average federal sentence for drug trafficking offenses (whuch unclude possession with intent to distribute) rose more than $40 \%$, from 59.3 months to 843 months See 1995 SOURCEBOOK, supra note 83, al 473 tbl.5.24.

191. On the expansion of mail and wire fraud, see Peler J. Henning, Maybe It Should Just Be Called Federal Fraud: The Changing Narure of the Mail Fraud Statuse, 36 B.C L. REV 435 (1995) On the expansion of other sorts of federal crime, sec, for examplc. Pamela $\mathrm{H}$. Bucy. Crmes by Heallh Care Providers, 1996 U. ILL. L. REV. 589; Brian T. FitzPatnck, Congressional Re-Elechon Tirough Symbolic Politics: The Enhanced Banking Crime Penalies, 32 AM CRLM L. REV I (1994): Richard J. Lazarus, Meeting the Demands of Integration in the Evolution of Entronmental Law: Reformung Entronmental Criminal Law, 83 GEO. L.J. 2407 (1995); and Rachel Ratliff. Thurd.Party Mloney Launderng Problems of Proof and Prosecutorial Discretion, 7 STAN. L. \& POL'Y REV. 173 (1996).

192. 18 U.S.C. $\$ 1346$ (1994). For an example of the kind of intangible harm that this statute covers, see Unired States v. Margionta, 688 F.2d 108 (2d Cir. 1982). See also John Calvin Jeffnes. Jr., Legality. Vagueness, and the Construction of Penal Statuses, 71 VA. L. REV 189. 23+-42 (1985) (discussing Margiotta).

193. The "intangible rights" protected by federal fraud statules include the nght to honest government services; the consequence is to crnminalize the use of private inlluence of as sor that has been the norm in many jurisdictions on matters such as government hinng If, for example, a pnvate citizen who plays a 
violation of reporting requirements for large cash transactions, but also the intentional structuring of those transactions to avoid reporting. In other words, altering one's course of action to comply with the reporting rules can be just as much a crime as violating those rules, and this is so even if the defendant did not know that such behavior was prohibited. ${ }^{194}$ Criminal insider trading does not necessarily require either proof of breach of a fiduciary duty or proof that the defendant profited from the inside information. ${ }^{195}$ There are many other examples.

The breadth of these statutes, like the breadth of RICO and drug forfeiture laws, does not mean that Congress intends actually to punish the entire range of conduct it criminalizes. The more likely goal is to reduce the burden of proving core offenders guilty. The government may wish to punish people who satisfy criminal elements $X, Y$, and $Z$, but if $Z$ is difficult to prove it is cheaper to criminalize $X$ and $Y$ and let prosecutors separate the wheat from the chaff. Hence the removal of elements like reliance, tangible injury, breach of duty, and knowledge of possible illegality from a range of regulatory crimes-elements that are probably present in almost all of the cases Congress and federal prosecutors wish to pursue, but that are costly to prove.

Federal law and practice is where overcriminalization and oversentencing seem most prevalent-and, not coincidentally, that is also where defendants with resources are concentrated (which makes overcriminalization especially useful from the government's perspective). Yet a version of the same phenomenon occurs on a smaller scale at the state level, and not only to wealthy defendants. Criminal sodomy laws, where they remain on the books, serve as useful devices for extracting guilty pleas in sexual assault cases. ${ }^{196}$ The same is probably true of marijuana laws in jurisdictions where those laws go largely unenforced; such unenforced prohibitions may be used as vehicles

major role in local Republican or Democratic politics tries to get a friend a government job in return for the friend's help on a business transaction, the private citizen has committed mail or wire fraud. See Stuntz, supra note 5, at 14 \& n.37 (citing sources).

194. In Ratzlaf v. United States, 510 U.S. 135 (1994), the Supreme Court held that such conduct was not criminal. The defendant in Ratzlaf was charged under 31 U.S.C. $\$ 5322$, which made it a crime "willfully" to violate 31 U.S.C. § 5324, which in tum forbade particular sorts of strategic structuring of currency transactions. The Ratzlaf majority read the word "willfully" in $\$ 5322$ to require proof of knowledge of illegality. See 510 U.S. at 141-49. Congress overturned this result by taking $\$ 5324$ offenses out of $\S 5322$, and by adding to $\S 5324$ a new subsection, defining criminal violations without use of the term "willfully." See Act of Sept. 23, 1994, Pub. L. No. 103-325, 108 Stat. 2253, 2254 (codified at 31 U.S.C.A. § 5324(c) (West Supp. 1997)).

195. One can criminally violate 15 U.S.C. $\$ 78 \mathrm{n}(\mathrm{e})(3)$ and Securities and Exchange Commission Rulc 14e-3, 17 C.F.R. $\$ 240.14$ e-3 (1997), without either breaching a fiduciary duty or profiting from the inside information. See United States v. Chestman, 947 F.2d 551 (2d Cir. 1991) (en banc). The Supreme Court reinforced this conclusion last Term by holding that the SEC did not exceed its rulemaking authority in adopting Rule $14 \mathrm{e}-3$ (a) without making breach of a fiduciary duty an element of the rule's violation. See United States v. O'Hagan, 117 S. Ct. 2199, 2214-19 (1997).

196. For examples of this phenomenon, see Sylvia A. Law, Homosexuality and the Social Meaning of Gender, 1988 WIS. L. REV. 187, 189 \& n.9; and Mitchell Lloyd Pearl, Note, Chipping Away at Bowers v. Hardwick: Making the Best of an Unfortunate Decision, 63 N.Y.U. L. REV. 154, 156-57 \& nn.14-15 (1988). 
for prosecuting people suspected of other, more serious offenses. Those are examples of legislative passivity, of broadening criminal liability by leaving on the books prohibitions that once were taken seriously but no longer are. Other examples of state-law substantive manipulation are more straightforward. Facing an Eighth Amendment proportionality challenge, Michigan defended its high mandatory sentences for cocaine possession as a means of punishing distribution without having to prove it. ${ }^{197}$ And traffic offenses are farnously used to create authority to stop drivers suspected of other crimes. ${ }^{198}$ Like unenforced crimes used to prosecute more traditional offenses, these practices use substantive law to evade what would otherwise be expensive criminal procedure requirements.

The greater the burdens these requirements impose, the more the government gains from following this strategy. Jury trials are expensive, especially given the way constitutional law regulates jury selection. But overbroad offenses and high nominal sentences may save the government the cost of a good many jury trials by making trials either pointless or risky for defendants, who are thereby pushed to plead guilty. This effect applies not just to the law surrounding juries, but to virtually everything in criminal procedure. At the margin, every pro-defense procedural rule raises the gain to the government from overcriminalization. ${ }^{199}$

And, ironically, overcriminalization tends to make criminal litigation ever more focused on procedure. If tangible injury and reliance are elements of mail fraud, defense counsel in some mail fraud cases will devote their energies to those issues. If, on the other hand, fraud does not require proof of those elements, fewer defendants will have potential merits claims to raise-for them, litigation can only mean procedural litigation, challenges to grand jury subpoenas and the like. The natural legislative response to too much procedure works, in the sense that the government wins more cases more easily, but it also makes for litigation that is more procedure-intensive than ever.

I do not mean to overstate the imponance of this dynamic. Overcriminalization and high mandatory sentences are not solely or even primarily the product of criminal procedure; other, more visible forces are at work as well. But the coincidence of these trends is at least interesting, and perhaps telling. Federal criminal liability has broadened considerably over the past generation, at the same time that constitutional criminal procedure has exploded. And broader liability, together with other devices that tend to combat defendants' wealth advantage, has been most marked in those areas where criminal procedure rules have most raised the cost of prosecution.

197. See Harmelin v. Michigan, 501 U.S 957, $1024-25$ (1991) (Whute. J. dissentung) (nutung and rejecting the argument).

198. See Whren v. United States, 116 S C 1769 (1996) (allowing the prattuce)

199. The preceding three paragraphs, with some modification. dre drawn from Stuntz, supros note 5 . at $14-15$. 


\section{Appellate Courts' Perceptions}

Part of the genius of the common law is its self-correcting process. Appellate courts make law, the consequences of which tend to show up in cases that make their way back to appellate courts. If new doctrines have (unanticipated) bad consequences, appellate courts usually see them, and can move to correct their mistakes.

Not so with the law that governs the criminal process. That law tends to generate legislative moves-lower funding for criminal defense and broader criminal liability for wealthier defendants-that hide its costs. In the past generation, these moves have been reinforced by a social phenomenon: higher levels of crime, which raise the ratio of crimes to prosecutors. Taken together, these forces have made constitutional criminal procedure seem, from the courts' perspective, surprisingly inexpensive. If prosecutors' offices had a great deal of slack, expanded rights for criminal defendants might lead directly to large numbers of government losses in the courtroom. In a world where prosecutors work at or near capacity, where there are more good cases to bring than there is time to bring them, expanded rights are more likely to prompt prosecutors to substitute some cases for others. The courts see no sharp rise in defense victories, and hence see the relevant constitutional rules as cheap. So too, if criminal defense were funded generously, developments in constitutional criminal procedure might tend to raise the level of defense litigation: More cases might go to trial, and trial length might increase. But when funding is low, criminal procedure tends to shift defense litigation from some claims to others. Again, courts see no dire consequences from the law they create.

This is not to say that courts see no consequences at all. For reasons spelled out in preceding sections, a world with heavy procedural regulation and low levels of defense funding will tend to produce criminal litigation focused on procedure-a fairly high number of suppression motions coupled with a low level of factual investigation and an even lower level of factual litigation. The level of criminal prosecution may not decline (as it hasn't), and the frequency of government victories may remain constant or even increase (as it has), but the kind of litigation courts see-perhaps especially the kind of litigation appellate courts see-will tend to shift from fact claims to law claims, from the merits of the criminal charge to the merits of the criminal process.

So, in a world like ours, appellate courts are likely to see a system that appears to function as it should: Defendants' many procedural rights seem to work (hence the fairly high level of Fourth, Fifth, and Sixth Amendment litigation on appellate courts' criminal dockets, which suggests aggressive enforcement), but those same rights seem not to prevent the government from catching and punishing criminals (hence the continuing high level of government success on outcomes and especially the high level of guilty pleas). 
Meanwhile, the absence of large numbers of serious sufficiency-of-theevidence claims tends to suggest that such claims must not exist-that absent the very, very rare exception, all convicted defendants are guilty.

There are two natural responses to this misleadingly happy picture, and appellate courts have exhibited both over the course of the last generation. The first is not to worry much about guilt and innocence. The absence of strong merits claims and the huge proportion of guilty pleas suggests to courts (wrongly) that the system must be doing a good job of separating those who committed crimes from those who did not. And rigorous attention to the merits is costly, for it requires a serious analysis of the whole record. If the system is doing a good job of sorting, that cost need not be borne.

One sees this reaction mostly in the paths the law of criminal procedure has declined to follow. As the scope of various constitutional protections has continued to expand, judicial review targeted at potential errors on the merits-at cases where the wrong person was convicted-has been surprisingly muted. When, for example, the Supreme Court established constitutional sufficiency-of-the-evidence review in 1979, Justice Stevens predicted that federal judges would be swamped by the resulting additional work. ${ }^{200}$ The flood of new work never materialized, in part because appellate treatment of the relevant claims has been so perfunctory. Ineffective assistance doctrine, created in the 1970s and 1980s, has regulated conflicts of interest much more rigorously than it has regulated attorney decisions not to make plausible factual arguments. ${ }^{201}$ The Court's 1985 decision in Ake v. Oklahoma, ${ }^{202}$ requiring appointment of mental health experts to assist in preparing a criminal defense, has had few ripple effects, remaining basically restricted to the very small pool of insanity defense claims that go to trial. ${ }^{203}$ The constitutional requirement that the government disclose material exculpatory evidence has yet to be extended to and enforced at early stages of plea negotiation, where the defense has most need of disclosure (because counsel has usually done no investigating of her own). ${ }^{204}$

Most strikingly, as the Supreme Court and lower appellate courts have developed standards of review for different kinds of constitutional claims, the courts consistently have adopted more favorable standards of review for non-

200. See Jackson v. Virginia, 443 U.S. $307,337-39$ (1979) (Stevens, J , concumng in the judgment)

201. See supra note 74 and accompanying text

202. 470 U.S. 68 (1985).

203. See David A. Harris, Ake Revisited: Expert Psychratric Wimesses Reman Beyond Reach for the Indigent, 68 N.C. L. REV. 763, 769-80 (1990).

204. See Kevin C. McMunigal, Disclosure and Accuracy in the Gulty Plea Process, 40 Hastwos LJ 957, 957-58 (1989) (noting that the applicabiluty of Brady v Manland. 373 U S 83 (1963). to guilly pleas remains unresolved). The Supreme Coun has never addressed the issue A few lower coun eases state that the government's disclosure obligation does apply to guilty pleas but go on to conclude that Brady was not violated. See, e.g., Sanchez v. United States, 50 F.3d 1.448 (9th Cir. 1995): United States v Wright, 43 F 3d 491 (10th Cir. 1994). Cases overtuming guilty pleas based on Brady volutions are almost nonexistent See McMunigal, supra, at 962-64 (discussing the lower court cases) 
guilt-related claims than for those claims most likely to be tied to guilt and innocence. The erroneous denial of Fourth Amendment and Miranda claims must be harmless beyond a reasonable doubt for the government to escape reversal on appeal. ${ }^{205}$ But a defendant making an ineffective-assistance-ofcounsel claim (again, outside of conflicts of interest, which may be least tied to guilt or innocence and which require no showing of prejudice at all $)^{206}$ must show a reasonable probability-substantially more than a reasonable doubt-that counsel's error or errors caused the defendant's conviction. ${ }^{207}$ The same tougher standard applies to claims that the government wrongfully withheld material exculpatory evidence. ${ }^{208}$ Nonconstitutional claims of newly discovered evidence, of course, must meet an even tougher standard: The new evidence must not only have been unavailable at the time of trial but must also prove that the result reached at trial was probably wrong. ${ }^{209}$

The second natural response to the picture of criminal litigation that appellate courts see is to tilt toward more constitutional regulation of the process, since such regulation seems both effective and (unlike more careful attention to the merits) cheap. That may help to explain the unusual pattern of the past generation in criminal procedure. Beginning in the early 1970s and running through the 1980 s, the ideological composition of the Supreme Court shifted dramatically, and a parallel, less dramatic shift occurred in the federal judiciary as a whole. The general expectation was that this personnel change would be the undoing of the constitutional revolution in criminal procedure of the 1960s. Nothing of the sort happened. Some Warren Court decisions suffered cutbacks, but the dominant pattern of the 1970s and 1980s was further expansion of protections for criminal defendants. It is as if, after the late 1930s, the Roosevelt Court had not only left Lochner ${ }^{210}$ intact but actually used it to bar new kinds of government regulation.

Consider the bodies of criminal procedure doctrine that either did not exist when Earl Warren retired or that were fairly trivial then but are both enormous and important now: everything concerning jury selection-both the fair crosssection doctrine $\mathrm{e}^{211}$ and the line of equal protection cases that govern peremptory challenges ${ }^{212}$-the doctrine of ineffective assistance of

205. See Brecht v. Abrahamson, 507 U.S. 619, $629-30$ (1993) (Miranda violations); Chambers v. Maroney, 399 U.S. 42, 52-53 (1970) (Fourth Amendment violations).

206. See supra note 74 and accompanying text.

207. See Strickland v. Washington, 466 U.S. $668,691-96$ (1984).

208. See United States v. Bagley, 473 U.S. $667,680-83$ (1985) (plurality opinion); id. at 685 (White, J., concurring in the judgment).

209. See Strickland, 466 U.S. at $693-95$ (contrasting the newly discovered evidence standard with the reasonable probability standard the Court adopted for ineffective assistance claims).

210. Lochner v. New York, 198 U.S. 45 (1905).

211. See Duren v. Missouri, 439 U.S. 357 (1979); Taylor v. Louisiana, 419 U.S. 522 (1975).

212. Batson v. Kentucky, 476 U.S. 79 (1986), first made it possible to establish an equal protection violation based solely on the government's use of peremptory challenges in the case at hand. See also J.E.B. v. Alabama ex rel. T.B., S11 U.S. 127 (1994) (applying the Batson rule to gender-based strikes); Georgia v. McCollum, 505 U.S. 42 (1992) (applying the Batson rule to strikes by defense counsel); Powers 
counsel, ${ }^{213}$ virtually all the law related to guilty pleas, ${ }^{214}$ the double jeopardy doctrine governing successive use of criminal and civil penalties, ${ }^{215}$ most of the Sixth Amendment law governing post-indictment or postarraignment police questioning, ${ }^{216}$ the law governing the use of force by police officers, ${ }^{217}$ and the law governing arrest warrants and when police have to get them. ${ }^{218}$ This list does not include the huge mass of law regulating the imposition of capital punishment, all of which has come into being since 1976. ${ }^{219}$ The conventional wisdom is that these developments simply involved the fleshing out of (and often cutting back on) Warren Court decisions, that criminal procedure doctrine has become more conservative, less restrictive, even as the doctrine itself has grown. But most of the areas just mentioned involve no judicial fleshing-out; they represent new departures, constitutional regulation of things that were formerly not regulated. Conservative and liberal Justices alike have led the march toward ever more constitutional restriction of the criminal process. Indeed, the scope of criminal procedure has probably expanded as much in the past two (conservative) decades as it did in the more liberal 1960s.

In a society with lower crime rates, higher levels of funding for criminal defense, and more restrictive criminal statutes, these various sons of procedural regulation would have seemed costlier, more of a hindrance to prosecutors and the police. Changes in the ideological leanings of the judiciary might have played a larger role in the law's development-as they have in a range of other constitutional areas (think of the last two decades' Supreme Court decisions

v. Ohio, 499 U.S. 400 (1991) (holding that the defendant need not be of the same race ds the jurors struck in order to make out a Basson claim).

213. Lower cours began to develop ineffectuve assistance docinne in the 1970s See. e 8 . United States v. Decoster, 624 F.2d 196 (D.C. Cir. 1979) (en banc) The Supreme Court defined the constitutional law governing conflicts of interest in the 1970s and 1980s See Holloway Y Arkansus, +35 U S 475 (1978); Cuyler v. Sullivan, 446 U.S. 335 (1980); Burger v Kemp. 483 U S 776 (1987) With respect to the main body of ineffective assistance doctrine, the Court first entered the field in 1984 See Strickland, 466 U.S. 668 (1984); United States v. Cronic. 466 U S 648 (1984)

214. Constitutional regulation of guilty pleas basically began with Brads , Umied Srates. 397 U S 742 (1970), which expressly permitted some forms of plea bargauming and hence opened the dow to regulation of the bargaining process.

215. See Montana v. Kurth Ranch. 511 U.S 767 (199.4). United States v Halper. $4(00)$ U S 435 (1989)

216. Of course, Massiah i: United States, 377 US 201 (1964). whith establashed the Stxth Amendment right to be free from certain forms of post-charging police questioning. was a Warten Cuurt decision. But Massiah was widely regarded as a dead letter after M/randa v Arzona. 38+4 U S 436 (1966). which established a Fifth Amendment nght to counsel in the police interrogation selung It was the Burger Court that reinvigorated Massiah, giving it independent standing and developing an enture body of doctrine to define its bounds. See Michigan v. Jackson. 475 US 625 (1986). Masune r Muulton. 47t U S 159 (1985); United States v. Henry, 447 U.S. 264 (1980), Brewer v Willams. 430 U S 357 (1977)

217. The seminal cases on the constututional limits on deadly and nondeadly loree were nut decided until 1985 and 1989, respecuvely. See Tennessec y Gamer, 471 U S I (1985). Graham , Cunnor. 490 U.S. 386 (1989).

218. See Steagald v. United States, 451 U S 204 (1981). Payton y New Yutk. 455 U S 573 (1980)

219. The 1976 decisions from which all the law of capital punishment is destended are Raberts Louisiana, 428 U.S. 325 (1976); Woodson :: North Carolma, 428 U S 280 (1976), Juret I Texas, 428 U.S. 262 (1976); Proffitt v. Florida, 428 U.S. 242 (1976). and Gregg , Georgis. 428 U S 153 (1976) 
on affirmative action, campaign finance, religious freedom, and school desegregation). But the very existence of defendant-protective procedural doctrine tends to push toward lower funding and broader substantive criminal law. Together with the coincidence of higher crime rates, those forces make procedures cheap and, relatively speaking, ideologically uncontentious. The judicial right and left have continued to argue about the merits of particular Fourth, Fifth, and Sixth Amendment rules, and there has been some significant retreat from broad Warren Court protections in a few areas. ${ }^{220}$ But to a striking degree, argument about the enterprise of using constitutional law to shape the criminal process has been absent.

Interestingly, in some pockets of cases judges have seen heavy costs from constitutional regulation, and in those areas the Supreme Court has tended to move to cabin the costs. Large-scale drug prosecutions involve defendants with substantial resources; such cases also often raise plausible search and seizure claims. Not coincidentally, the Court has, by and large, cooperated with Congress in making forfeiture remedies effective in such cases, particularly through the device of freezing assets that might otherwise be used to hire expensive attorneys. ${ }^{221}$ More broadly, the Court's Fourth Amendment decisions have facilitated the use of informants and undercover agents in drug cases, even while restrictions on some other kinds of police investigation have grown. $^{222}$

220. One area of retreat has been the law governing the scope of the exclusionary rule. See Carol S. Steiker, Counter-Revolution in Constitutional Criminal Procedure? Two Audiences, Two Answers, $94 \mathrm{MICH}$. L. REv. 2466 (1996) (noting that remedies have been restrained more than have substantive rights). Another example is the law governing eyewitness identifications, where the Warren Court seemed to state a broadly protective standard that was largely undone by the Burger Court. Compare Gilben v. California, 388 U.S. 263 (1967) (finding constitutional error in the admission of in-court identifications of the accused because they may have been tainted by illegal line-up procedures), and United States v. Wade, 388 U.S. 218 (1967) (holding that the Sixth Amendment guaranteed an accused the right to counsel at a post-indictment line-up), with United States v. Ash, 413 U.S. 300 (1973) (holding that there is no Sixth Amendment right to counsel at a post-indictment photographic line-up), and Kirby v. Illinois, 406 U.S. 682 (1972) (holding that the Sixth Amendment right to counsel does not extend to pre-indictment identifications).

221. See Caplin \& Drysdale, Chartered v. United States, 491 U.S. 617 (1989); United States v. Monsanto, 491 U.S. 600 (1989); supra notes 107-110 and accompanying text.

222. The Court decided in 1971 that the use of undercover agents did not constitute a Fourth Amendment "search," thereby facilitating stings and fake buys in drug investigations. See United States $v$. White, 401 U.S. 745 (1971). In 1983, the Court relaxed the standards by which informants' tips could support a finding of probable cause. See Illinois v. Gates, 462 U.S. 213 (1983). This was particularly important for enforcement of drug crime, as the large majority of search warrants that rest on informants' tips are used in drug investigations. See RiChard VAN DUIZEND ET AL., ThE SEARCH WarRaNT Process: PRECONCEPTIONS, PERCEPTIONS, AND PRACTICES 41 \& tbl.2-12 (1985) (noting that, in seven cities studied, drug cases ranged from $55 \%$ to $96 \%$ of those cases in which warrant applications relied on informants' tips).

These developments obviously eased drug enforcement. Yet they were not part of a uniform pattern in constitutional regulation of police investigation. In a number of areas constitutional regulation of the police grew tougher after 1970. In police interrogation, for example, the Court revived Sixth Amendment restrictions, see supra note 216, and both strengthened and extended the prohibition on post-invocation police questioning, see Edwards v. Arizona, 451 U.S. 477 (1981) (holding that the invocation of the right to counsel bars subsequent police-initiated questioning); Arizona v. Roberson, 486 U.S. 675 (1988) (applying the Edwards ban to questioning about a different crime than the one for which the defendant was arrested); Minnick v. Mississippi, 498 U.S. 146 (1990) (holding that the Edwards ban continues to apply 
Similarly, capital murder defendants, though they often have poor-quality. underpaid counsel at trial, also often have very high-quality volunteer representation on habeas corpus. The result has been both a large volume of habeas litigation in capital cases and strikingly high success rates for capital defendants. ${ }^{223}$ The Court responded by moving to cut off habeas relief through restrictive procedural default and retroactivity decisions, decisions that applied to habeas generally but probably were designed with death penalty litigation in mind. ${ }^{224}$

But outside these and a few other categories, the Supreme Cour in particular and appellate courts in general do not see the costs of the procedural regulation the Court has undertaken over the past generation. Because the costs are unseen, because they take the form of cases not brought and claims not made, the Court has kept adding to the regulation. That in turn only raises the incentive for legislatures to limit resources and broaden criminal liability, thereby hiding the law's effects even more. In this particular legal dialogue, each side seems to encourage the worst in the other.

\section{A Different Constitutional Path: Substance and Funding}

To this point I have tried to explain why, given the existing allocation of power between courts and legislatures, our system suffers from a natural tendency toward a series of pathologies-overregulation of the criminal process, proceduralization of criminal litigation at the expense of the merits, overcriminalization, and underfunding of criminal defense-and why these pathologies tend to reinforce one another. I cannot establish precisely how much this natural tendency has caused, for many forces have been at work in the system, and there are a variety of causal stories one can tell about the phenomena I have discussed above. The existence of the pathologies is fairly clear. Their extent is not, and causal responsibility is guesswork.

after a suspect has met with his lawyer).

223. See Lay, supra note 148, at 1044 n 166

224. The Court moved to strengthen procedural default doctrine before death penslty litugution becime a significant problem. See Wainwright v. Sykes, 433 US 72 (1977) Sull. Sikes might huve meant much or little, and in the years since 1977 the Coun has consistendy chosen "much " The key decisions are, not coincidentally, death penalty cases. See Coleman v. Thompson, 501 U S 722 (1991). Murra) 、 Gidrratano. 492 U.S. 1 (1989); Murray v. Cartier, 477 U.S. 478 (1986)

The use of retroactivity doctrine as a vehicle for reining in habeas began wath Teague : Lane, 489 U.S. 288 (1989). Teague was not a death penalty case, but most of the Supreme Coun cases Ileshing it out have been. See Stringer v. Black, 503 U.S. 222 (1992). Sawyer v Smith. 497 U S 227 (1990). Sallle v Parks, 494 U.S. 484 (1990); Butler v. McKellar, 494 US 407 (1990), Penry v L.jnsugh, 492 U S 302 (1989). Other restrictions on habeas relief have likewise been crafted in eapital murder cases See McCleskey v. Zant, 499 U.S. 467, 489-97 (1991) (detalling abuse-ot-the-knt doctnne) th is hard to avotd the inference that the Cour has seen habeas as a vehicle for policing what it sees as excessive capital punishment litigation. See Joseph L. Hoffmann, Is Innocence Sufficient' An Essay on the US Supresne Court's Continuing Problems with Federal Habeas Corpus and the Death Penaln. 68 1No L I 817 (1993) 
Yet the broader trends of the past two decades, in both case law and legislation, do seem to fit the dynamic outlined in preceding sections. We not only have overbroad criminal liability; we have overbroad criminal liability especially with respect to crimes of the well-off, and those crimes are increasingly federal rather than state. And the scope of this liability has grown over the past three decades as criminal procedure has grown. We not only have a universe of criminal defendants that is disproportionately poor; the disproportion appears to be worse than it was two decades ago-again, as criminal procedure has grown. And though the point is necessarily impressionistic, we seem not only to have criminal litigation that focuses heavily on procedural/constitutional issues; that focus appears to have intensified steadily during the time of criminal procedure's growing reach.

All this sounds like an argument for less constitutional regulation-perhaps a lot less. Yet that is not the only message one can derive from the perverse dynamic between courts and legislatures. On the contrary, there is an argument here that constitutional law has been not too interventionist, but merely interventionist in the wrong places. Consider the two main aspects of criminal justice that constitutional law has left alone: the content of substantive criminal law and the allocation of resources within the system.

Serious constitutional regulation of substantive criminal law, if it existed, would have to take some combination of two forms. The first is a proportionality rule, requiring that the conduct criminalized be serious enough to justify the punishment attached to it. The second is an application of the first: a kind of criminal substantive due process, ensuring that the conduct criminalized was serious enough to justify some criminal punishment. The first sort of doctrine (which the Supreme Court briefly, but only briefly, embraced ${ }^{225}$ would bar oversentencing. The second would bar overbroad criminal liability. Both would bear directly on what one would think is the most important question the system faces: whether the people being punished deserve the punishment they receive.

Substantive constitutional regulation of this sort may be more workable than one might think. A proportionality requirement need not mean appellate review of every sentence. Courts might instead require that trial judges be given the power to revise sentences downward, that legislative guidelines be

225. See Rummel v. Estelle, 445 U.S. 263 (1980) (rejecting serious proportionality review); Solem v. Helm, 463 U.S. 277 (1983) (embracing it); Harmelin v. Michigan, 501 U.S. 957 (1991) (plurality opinion) (apparently rejecting it again). In Harmelin, the Chief Justice and Justice Scalia took the position that proportionality review of noncapital sentences is never required. See id. at 990-94 (plurality opinion). Justices Kennedy, $O^{\prime}$ Connor, and Souter concluded that while proportionality review is sometimes required, no comparison of sentences across crimes or across jurisdictions is necessary if the crime in question is serious-in that event, any noncapital sentence is automatically proportionate. See id. at 1004-05 (Kennedy, $\mathrm{J}$. , concurring in part and in the judgment). The same Justices also concluded that possession of a significant amount of drugs was serious. See id. at 1006. The upshot is that proportionality review is now unavailable for all major street crimes, for drug distribution, and for drug possession where the amount possessed was substantial. 
construed to set ceilings for sentences but not floors. Just as the finder of fact in a criminal case may acquit for any reason, notwithstanding the legislature's definition of the offense, ${ }^{226}$ perhaps the sentencer should have the constitutionally guaranteed option of leniency, again without regard 10 legislative instruction. (The parallels between the two are stronger than appears at first blush.) This would involve a dramatic legal change in an increasingly guidelines-dominated world where judicial discretion is receding. Yet dramatic though it is, this sort of legal change is hardly unthinkable, or unadministrable. After all, every American jurisdiction lived with broad sentencing discretion until fairly recently. ${ }^{227}$

Nor would constitutional limits on criminal law mean a wholesale judicial rewriting of criminal codes; two more modest changes could accomplish a great deal. First, courts could require proof of some level of culpability with respect to criminality for especially broad regulatory offenses-a mail fraud defendant charged with something well shy of traditional common law fraud could be entitled to argue that he had no idea his conduct was crimnal. A limited ignorance-of-the-law defense along these lines would provide substantial protection for defendants maneuvering through regulatory minefields. More importantly, it would limit prosecutors' ability to use overbroad statutes to force guilty pleas in questionable cases. The second change is familiar in the literature, ${ }^{228}$ though the legal system has never embraced it: Courts could forbid arrest or prosecution based on crimes that are not regularly enforced (or, as with traffic offenses, not regularly treated as crimes). ${ }^{229}$ A constitutionalized desuetude doctrine would bar the strategic

226. See Sanabria v. Unted States, 437 U.S 54 (1978)

227. See, e.g., Michael TonRY, SentenciNg Matters 4 (1996) ("In 1970, every stute and the lederal system had an 'indeterminate senteneing system' in which judges had wide discretion to decide who went to prison and to set maximum and someumes munimum pnson terms")

228. The argument is most commonly associated with GUibo CALABRESi. A COMMION LAW HOR THE AGE OF STATUTES (1982). For an earlier and much less developed version of the argument, sec Alexander M. Bickel, The Supreme Court, 1960 Tenn-Foreword The Passive Virmes. 75 Hakv L RbV 40.61.64 (1961).

229. This position would undo the decision in Whiren , Unred Srates. $116 \mathrm{~S} \mathrm{Cl} \mathrm{1709} \mathrm{(1996).} \mathrm{in}$ which the Supreme Cour held, in essence, that all "cnmes" are to be treated allke for Fuurth Amendment purposes. Whren permits the police to use traffic offenses in precisely the same way that the police used old-style vagrancy and loitering law: as a grant of discretuonary power to stop, question. and in jurisdictions that classify traffic offenses as crime) search and arrest suspects bused on unariculated suspicion of other crimes, or worse, based on the officer's whim or prejudice the result is fourth Amendment doctrine that appears to limu traffic stops but in pracuce joes nol

What the limit should be is a separate question. There are senous arguments tor the proposttion that the police need broad discretionary authority of the son that vagrancy and loutering buw once guve them-indeed, as Debra Livingston has shown, those arguments are th the hear of the curtent communuy policing movement. See Debra Livingston. Police Discretion and the Qualin of Lste in Public Places Courts, Communities, and the New Policing. 97 CoLUM L REV 551 (1997) Howerer much werght those arguments carry, limits on police discretion ought not to depend on ststes ability to identuly traftic-lype regulations that serve to authorize police action that is undertaken for other reasons 
use of non-crime "crimes," as where a contestable sexual assault case leads to a guilty plea to sodomy. ${ }^{230}$

Restrictions like these would raise the cost of prosecuting defendants charged with marginal or questionable crimes (not rich defendants, as constitutional criminal procedure does). They would thus tend to shift prosecutorial resources away from such crimes-a good thing, if courts would do a decent job of determining which crimes are questionable. To the extent substantive regulation would encourage a particular kind of defense claim at the expense of some other kinds of claims, the claim encouraged is closely tied to innocence; it bears directly on whether the defendant can fairly be punished, or punished to the relevant extent, for what he did. These allocative effects seem a good deal more benign than the effects of heavy regulation of procedure.

For a brief time in the 1960s, the law appeared ready to embrace this type of constitutional regulation. In 1957, Lambert $v$. California ${ }^{231}$ invalidated a law criminalizing nonregistration by felons; in its opinion the Supreme Court seemed to state a broad notice principle. ${ }^{232}$ In 1962, Robinson $v$. California $^{233}$ struck down a law criminalizing drug addiction, in an opinion that established the basis for a broad, constitutionally required voluntary-act norm. ${ }^{234}$ Three years later, the Court's decision in Griswold $v$. Connecticut, ${ }^{235}$ which overturned a criminal conviction under the state's anticontraception statute, suggested that a broad range of private conduct might be outside the scope of criminal law. And in the late 1960s and early 1970s, the void-for-vagueness cases struck down a series of loitering and vagrancy laws that police had used as street-cleaning statutes. ${ }^{236}$ These different strands might all have come together to form a body of substantive due process focused on criminal law, a set of constitutional limits that would prevent legislatures from criminalizing ordinary conduct or from relying on unenforced crimes as grants of discretionary power to law enforcers.

This possibility, the chance that constitutional regulation of criminal justice would be primarily substantive rather than procedural, is largely ignored today but must have seemed quite real to the legal community of thirty-five years

230. Both arguments are developed at more length in Stuntz, supra note 5, at 31-38.

231. 355 U.S. 225 (1957).

232. See id. at 228 ("Engrained in our concept of due process is the requirement of notice.").

233. 370 U.S. 660 (1962).

234. When Robinson was decided, it was widely seen as casting a shadow on a varicly of criminal drug statutes, including laws barring possession and use. See Michael R. Asimow, Comment, Constitutional Law: Punishment for Narcotic Addiction Held Cruel and Unusual, 51 CAL. L. REv. 219, 225-26 (1962); The Supreme Court, 1961 Term, 76 HARV. L. REV. 54, 146 (1962).

235. 381 U.S. 479 (1965).

236. See Papachristou v. City of Jacksonville, 405 U.S. 156 (1972); Coates v. City of Cincinnati, 402 U.S. 611 (1971); Shuttlesworth v. City of Birmingham, 382 U.S. 87 (1965). For a good discussion of the street-cleaning uses of such statutes, see Caleb Foote, Vagrancy-Type Law and Is Administration, $104 \mathrm{U}$. PA. L. REV. 603 (1956). 
ago. By the early- to mid-1960s, it was quite clear that the criminal justice system was being brought under constitutional control. But the nature of the control was up for grabs. Cases such as Mapp and Gideon pointed one way, Lambert and Robinson (and Griswold, a decision that has moved far afield from criminal law in ways that were not necessarily obvious at the (ime) (37 $^{23}$ the other. For a moment, a very different $\mathrm{mix}$ of procedure and substance seemed in the offing.

The moment passed. Powell v. Texas ${ }^{238}$ abandoned the broader reading of Robinson, and today the criminalization of low-level addictive behavior is routine. Inexplicably, Lambert's notice principle turns out not to matter. Almost nothing in existing doctrine tums on it, and Congress continues to criminalize a stunning array of conduct that its perpetrators would not likely suspect is criminal. ${ }^{239}$ Griswold took off, but in directions that were not at all tied to criminal law. ${ }^{240}$ And while vagueness doctrine survives, the overturning of vagrancy and loitering statutes has been all but undone: Traffic "crimes" now play the role that those statutes used to play-they authorize the police to stop and/or arrest whom they wish-albeit with a population in vehicles rather than on foot. ${ }^{241}$ While procedural regulation has continued to grow, substantive regulation has shrunk.

The story is slightly different, but with much the same bottom line, when it comes to the funding of criminal defense counsel. After Gideon :Wainwright, several years passed before the court system took seriously the problem of nominal representation-provision of a lawyer who failed to do the things good lawyers should do, either because of lack of time or because of incompetence. When in the 1970s such claims began to flood the courts, the universal judicial response was to define the issue in terms of the conduct of defense counsel, not the resource structure created by the state. ${ }^{2+2}$ Hence the

237. Though it did not use the word "cnminal," the Hanard Law Revew's discusston of Griswold emphasized that decision's tension with the long history of cnminal regulation of morals See The Supreme Court, 1964 Term, 79 HARV. L. REV. 103, 164-65 (1965). Alexander Bickel's famous commentary on Griswold's predecessor, Poe v. Ullman, 367 U.S. 497 (1961). stressed the virtues of requinng regular enforcement of criminal prohibitions, parly as a means of checking prosecutonal power and partly in order to force legislative reconsideration of outdated statules See Buckel. supra note 228, at 63.6-t These arguments suggest ways in which Griswold might have had more to do with the scope of substantive criminal law than with the scope of constitutionally protected privacy

238. 392 U.S. 514 (1968) (sustaining the conviction of an alcoholic for being drunk in public)

239. See supra notes 191-195 and accompanying text

240. Though the early abortion cases deall with criminal prohibutions, see Rue $Y$ Wade, +10 U' S 113. 117-19 (1973), those cases have consistently focused on privacy and reproductuve sutonomy. see, $\& g$. Planned Parenthood v. Casey. 505 U.S. 833. 850-53 (1992), not on the sorts of arguments that mighi have led to a broader consideration of the limits of criminal hability

241. See Whren v. United States, 116 S. C. 1769 (1996), supra note 229

242. For a good survey and analysis of the early ineffecluve assistance cases, see Gary Goodpaster. The Trial for Life: Effective Assistance of Counsel in Dealh Penaln Cases. 58 N Y U L ReV 299 (1983) As Goodpaster notes, these cases divided along different tests concerning allomey pertormance and prejudice. See id. at 339-52. 
law of ineffective assistance of counsel focuses wholly on defects in counsel's performance and the prejudice that results from those defects. ${ }^{243}$

If this constitutional regulation of defense counsel's performance had worked, it would have regulated funding indirectly. Sixth Amendment law would force counsel to perform to a given level, thereby forcing states to spend whatever it took to permit counsel to perform to that level. But the regime failed. No one has yet figured out a good mechanism for defining a reasonable level of representation-more importantly, no one has figured out a way to define a reasonable level of attorney investigation. The difficulty is that some cases may call for almost no effort while others require a lot; separating the categories is at least expensive, and at most impossible. The law has responded by retreating to the model of the discrete attorney error. Insufficient investigation is basically left alone. The upshot is that Gideon, while not trivial, means vastly less than it seems. Defendants receive counsel, but counsel must bear caseloads that require them to start with a strong presumption against any significant investment in any given case.

As with constitutional regulation of criminal substance, it need not have been this way. Instead of seizing on counsel's performance in the ineffective assistance cases of the 1970s, courts might have sought to enforce minimum levels of funding for public defenders' offices and minimum levels of pay (or higher caps) for separately appointed counsel. The rationale for such requirements seems obvious: Absent sufficient resources, counsel cannot function as counsel; thus, Gideon requires some budgetary floors if it is to fulfill its promise. Arguments of this sort have been explored, tentatively, by a few state courts, but only recently. ${ }^{244}$ The exploration might easily have come sooner and more aggressively.

Had it followed this path, the system would likely be substantially fairer, in ways that are biased in favor of rather than against the poor. As with substantive regulation, the perverse consequences that flow from an aggressive constitutional law of criminal procedure would not necessarily follow from constitutional funding requirements. Nor would funding requirements automatically involve the courts in impossible managerial difficulties akin to those that (on some accounts) have bedeviled litigation over school systems and prisons. A requirement of adequate resources need not mean judicial regulation of how those resources are allocated within public defenders' offices. ${ }^{245}$ No judicial micromanagement would be necessary. Unlike prison

243. See Strickland v. Washington, 466 U.S. $668,687-96$ (1984).

244. See cases cited supra note 78.

245. One important caveat should be noted. Because public defenders are salaried, a rise in budgets could leave caseloads unaffected if, for example, the added funds were spent on raises rather than on hiring more attorneys (along with office space and staff to serve them). Something like this may have happened over the course of the past generation: In her study of Chicago public defenders, Lisa McIntyre reports that the once-enormous salary differential between prosecutors and public defenders had virtually disappeared by the 1980 s. See MCINTYRE, supra note 22 , at $90-91$. The greater the tendency to raise salaries rather than 
cases, testing compliance with judicial decrees would seem to be easy: Either the required appropriations were made or they weren't. And unlike school cases, courts would not need to worry that private parties could defeat regulation, as parents defeated desegregation decrees by moving their children to different districts or by placing them in private schools. Funding requirements would be, as a practical matter, impossible to evade. ${ }^{2+6}$

In short, both substantive regulation and funding requirements would directly address serious and common injustices, would be doctrinally plausible, and would lack the kinds of perverse side effects that fow from extensive regulation of criminal procedure. To be sure, a constitutional law of substance and funding would itself require some limits on the criminal process in order to avoid legislative evasion: Substantive limits and funding requirements are of little value if the state need not prove the defendant guilty of anything. But the provision of counsel, some sort of trial process, and a requirement of a high standard of proof in contested cases should be enough. The kind of criminal procedure doctrine that tilts the risk of error in the defendant's favor would be necessary. The kind of doctrines that regulate everything from trial management to street-level policing would not.

This point is important, for the relationship is not symmetrical. If extensive limits on the criminal process are to work as intended, if they are not to generate perverse side effects, they require serious constraints on legislative definition of crimes and on legislative allocation of resources. Constitutional criminal procedure is imperialist: It demands judicial control over the whole

to expand capacity, the more cours would be pressed to regulate not only overall funding levels but the salary structures of public defenders' offices as well. At the same ume, a wortable baseline exists for that second sor of regulation: It would be hard to justify the need to pay public defenders more than local prosecutors.

246. This is a partial answer to Gerald Rosenberg's claum that judicial reform eflonts of this son are essentially impossible to pull off. See ROSENBERG. supra note 94. At 334-35 A mulder verston of the clum is quite right, and Rosenberg deserves a greal jeal of credil for making $॥$ Judge-dnven suitul and institutional reforms tend strongly to have less real-world impact than one would suspect from reading the cases; this follows from the fact that judicial orders must be filtered through a vanety of uther institutions and actors in order to reach the world on the ground At least withn the criminal justuce system. judgemade rules also tend to have different effects from those one would expect. (This last pattern may extend beyond criminal justice: For an insightul and well-documented argument that the Supreme Coun's desegregation decisions' chief direct effect was to cmpower segregitionist politiclans, who in ium inadvertently helped civil rights leaders mobilize Northern public opinion in the 1960 s, see Michacl J Klarman, Brown, Racial Change, and the Cirll Rights Moremem, 80 VA L. Rev 7 (1(\%)4)) But beyond these mild generalizations, the effects of legal change must depend on what legal change one ts talking about. Some judicial directives are vastly easier to evade than others, some rules are more exposed than others to nullification by official discretion. The example that dnves Rosenberg's book. desegregation. is rife with opportunities for evasion, both by officials and by provate actors That is true to some degree of criminal procedure as well, though for its own paricular reasons. Cruminal procedure has had perverse effects, not because that is a necessary pattem to consututional lawmaking. but because of the system's allocation of authority between courts and legislatures and the incentuves procedural rules created for legislatures, prosecutors, and defense counsel. If that allocation of authority were altered-it, for example. courts had greater control over funding-and if constitutuonal law paud more attention to substance and less to procedure, one should not assume that comparable perverse effects would likely follow Whale limits on substantive criminal law and funding of cnminal defense would no doubi generate therr own enors and unintended consequences, they would not create the same perverse incentuves as commal procedure 
system. That is not true of a constitutional law of criminal substance, nor of constitutional standards for paying appointed criminal defense counsel. Constitutional law can regulate procedure effectively only by also regulating everything else; it can regulate substance and funding and still leave most of procedure alone.

Which leads to an obvious question: Why has constitutional law focused so heavily on criminal procedure, and why has it so strenuously avoided anything to do with substantive criminal law and the funding of defense counsel? By the early 1970s the pattern was probably set, and from that point on constitutional law's path may have been self-reinforcing: Procedure begat more procedure, for reasons I have tried to explore above. Yet that path was not from the first inevitable; powerful reasons counseled a different approach. Why then the turn away from substance and toward process?

Part of the answer is historical. Constitutional criminal procedure has deep roots; constitutional criminal substance and constitutional funding requirements do not. There is something to this answer, but not much. The large majority of the law of criminal procedure is of very recent creation; the field basically did not exist until a few decades ago. It is hard to argue that our constitutional roots require a regime that no one imagined until almost two centuries after the Constitution was ratified, and one century after the Fourteenth Amendment redefined the federal-state relationship. Another part of the answer has to do with constitutional text: The Bill of Rights says a great deal about criminal process and nothing about substantive criminal law or spending for defense lawyers. This too is less of an explanation than first appears. The texts of the Fourth, Fifth, and Sixth Amendments do not dictate the large body of law that exists in their name. We could have a very small and unobtrusive law of criminal procedure - as we mostly did until a generation ago-with no violence to the text. Proof of that proposition lies in the extreme rarity of textual argument in this area. ${ }^{247}$

Meanwhile, substantive criminal law could be constrained quite easily under the authority of the Due Process Clause and the Eighth Amendment. The prohibition of cruel and unusual punishments could plausibly be read to imply a proportionality principle for sentencing, capital and noncapital alike. And, in Lambert, due process already has been read to require notice, which in turn suggests that criminalizing conduct in which ordinary people might innocently engage should be impermissible. ${ }^{248}$ As for funding, a decent level of resources for criminal defense counsel is a natural extrapolation from the Sixth Amendment's requirement to appoint counsel for indigent defendants. None of these arguments requires a huge stretch in terms of text or structure. They

247. Akhil Amar's work is a notable exception to this tendency. See AMAR, supra note 1; Akhil Reed Amar, Double Jeopardy Law Made Simple, 106 YALE L.J. 1807 (1997).

248. See supra notes 231-232 and accompanying text. 
perhaps require abandoning original intent as a baseline, but that bridge has already been crossed: No one thinks current Fourth. Fifth, and Sixth Amendment law is faithful to the Framers' wishes. In shor, neither the Constitution nor history bars a very different relationship between constitutional law and criminal justice than the one we now see.

The real difficulty with regulating substantive criminal law and funding decisions may be more basic. There is no nonarbitrary way to arrive at the proper legal rules, no way to get to sensible bottom lines by something that looks and feels like legal analysis. Whether proportionality review is lodged in appellate or trial courts, the only way to do it is to do it, to decide that this sentence is too great but not that one. There is no metric for determining right answers, no set of analytic tools that defines what a given sentence ought to be. That, after all, was the problem with discretionary sentencing regimes, the problem that produced the current infatuation with guidelines. Similarly, heightened mens rea requirements for overbroad crimes beg the question of which crimes are overbroad. Special culpability rules for, say, mail fraud would inevitably rest on a judicial judgment that mail fraud is badly defined, that Congress criminalized more than it should have. Desuetude appears simpler, as it requires only that courts determine whether a given offense is regularly enforced. But regular enforcement is both hard to define and hard to determine; judges would likely retreat to asking whether they would have expected this behavior to be treated as a crime. All this amounts not just to open-ended judicial regulation-constitutional law has a lot of that, and courts do not seem terribly bothered by it-but also to arbitrary judicial regulation, regulation that produces outcomes untethered to any definable legal principle. This unanchored quality is precisely what defeated serious proportionality review of long prison terms, ${ }^{249}$ and why, this past year, the Supreme Court rejected the argument that traffic "crimes" do not count for purposes of authorizing some kinds of searches and arrests. ${ }^{250}$ Perhaps it is also why Lambert has had so little doctrinal impact.

Similarly, the only way to set funding floors is to set them-to say, states must spend this much on criminal defense, but need not spend more. There is no analytic structure that allows one to specify the right dollar amount. ${ }^{251}$ (Note the contrast with contemporary state cases about equalization of school funding, where some measure of equality across districts provides a workable baseline. $)^{252}$ A good deal of constitutional law may consist of judicial policy

249. See Harmelin v. Michigan, 501 U.S 957.985 .90 (1991) (pluralıy opınion), ud At 998-1001 (Kennedy, J., concurring in part and concurnng in the judgment)

250. See Whren v. United States, 116 S. Ct. 1769. 1774-77 (1996)

251. And note that the right dollar amount will differ from place to place. depending on (among other things) the mix of crimes in the relevant jurisdiction.

252. For a good survey of these cases, see Peicr Enrich, Leaiung Equaling Belind New Direchons in School Finance Reforn, 48 VAND. L. REV. 101 (1995). Ennch notes that funding dispanties have proved remarkably persistent, even in jurisdicuons where courts have intervened to equalize the disparities See 
preferences with a thin legal veneer, but here the veneer seems transparent.

That simple point may be the source of much of constitutional law's troubled relationship with criminal justice. Constitutional law has focused relentlessly on the sorts of issues that are susceptible to legal analysis-how to select juries, when to require warrants, which mistrials permit retrial and which ones mean the defendant must go free. These are classic lawyers' issues; they give rise to classic lawyers' arguments. But courts' decisions on those issues are embedded in a system shaped by more open-ended-and more flagrantly political-judgments: How bad should something be before we call it a crime? How much money should we spend on criminal defense? Perhaps courts would do a sufficiently poor job of making these open-ended political judgments that we are better off leaving them to other actors. That is the system's current premise, and the premise is entirely plausible. But if that premise is right, those other actors-chiefly legislators and prosecutors-are able to defeat courts' work on courts' own turf: All those judge-made procedural rules are likely not to work the way they are supposed to. In the criminal justice system's three-legged stool-procedure, substance, and money-procedure is the least stable leg, the one that most depends on the others for support.

So criminal procedure may be no more than an instance of courts properly recognizing the need to intervene in a system that imposes terrible costs on large numbers of people, and then doing what comes naturally, regulating the kinds of things courts are used to regulating. That includes avoiding a kind of decisionmaking that, for courts, seems unnatural. All of which might be fine if the judicially regulated sphere could be isolated from the rest of the system. Sadly, it cannot.

\section{CONCLUSION}

It is hard to know what to make of the law of criminal procedure. It plainly prevents some serious wrongs: Supposed murderers who refuse to admit guilt cannot be executed without trials at which they have lawyers and juries that find them guilty beyond a reasonable doubt; supposed rapists cannot be sent to prison for decades based on confessions that the police beat out of them; a black suspect in the robbery of a white store clerk cannot be sent to prison by the verdict of a jury from which all blacks were struck. These are very important benefits.

There are other benefits too, ones I have not discussed here. Criminal procedure shapes the behavior of regulated actors in some productive ways:

id. at 102-03. That hardly seems surprising, given the problems in implementing judicially mandated funding orders. Voters in local elections and parents deciding where to live and whether to enroll their children in private school can go far toward defeating most judicial orders. This kind of evasion is harder to imagine for funding requirements for criminal defense. 
Police officers are somewhat less likely to ransack someone's home on a whim than they would be in a system that left police investigation to local regulation. Here as elsewhere, legal prohibitions tend to deter the prohibited conduct (though deterrence is undermined by prosecutors' ability to select among strong cases, and by defense counsel's inability to raise all plausible claims). Where the prohibitions are sensible, that counts as a social gain. I have avoided discussing these benefits not because they are unreal or trivial, but because they are familiar.

Yet there are substantial tradeoffs, and the tradeoffs are not so familiar. The criminal process is much harder to control than courts suppose; it is driven by forces the courts do not, and perhaps cannot, direct. When courts do act, their actions are shaped by those forces in ways the courts themselves may not understand, ways that are at best ambiguous and at worst bad. Some part of what the Fourth, Fifth, and Sixth Amendments protect has probably come at the cost of a criminal justice system that is less focused on the merits and hence more likely to convict innocents, a system that disproportionately targets the poor, and a system that convicts for "crimes" that cover vastly more than anyone would wish to punish. The merits of this bargain are at least open to question.

Does that mean constitutional criminal procedure should be scrapped? No: Limits on police violence are essential to a free society, just as Gideon and the reasonable doubt rule are essential to any adversarial system that takes accuracy seriously. Now ask the question differently: Should the law of criminal procedure be scaled back, perhaps dramatically? Maybe so-not because it is wrong in principle, but because it is at odds with the system in which it operates. Where the scaling back should come and how substantial it should be depend, of course, on piecework evaluation, of both the norms on which particular bodies of law rest and the consequences they generate. But that evaluation should begin with a sense of the limits of the enterprise, the difficulty of doing what criminal procedure seeks to do without also doing other, much worse things.

Curiously, this kind of doctrine-by-doctrine assessment has never really happened. Debate about consequences in the literature on criminal procedure has been thin, to say the least. ${ }^{253}$ And that thinness has corrupted the debate

253. The literature on Miranda is a strikung example Polsce interrogation is generally thaught to be a terribly important feature of the craminal process, and Mtronda marked a sharp chunge in the law's treatment of police interrogation. But as Paul Cassell has noted. until the past couple of years neather courts nor academics paid any attention at all to Miranda's effects. simply assuming that the case did not malter much. Recent work by Cassell, Richard Leo, and Stephen Schulholer has done a greal deal to remedy this inattention. In addition to sources cited supra note 160, see Stephen J Schulholer. MItranda's Prucrical Effect: Substantial Benefits and Vanishingly Small Social Cosis. $90 \mathrm{NW} \mathrm{U} \mathrm{L} \mathrm{Rrv} 500$ (1996)

Of course, one can always complain about the lack of attention to empincs. that gripe is hardly unique to this field. The inattention to consequences an cnmınal procedure goes deeper Cunsequenualist theory has been as thin as empincal testing. The upshot is an inddeyuate sense of the likely cllexts ol doctrinal variation at the margin 
about norms. For the past thirty-five years, the legal system's discussion of criminal defendants' rights has suffered from an air of unreality, a sense that all goals can be satisfied and all values honored-that we can, for example, have the jury selection process we want at no cost to anything else we might want. A sense of rank ordering, of assigning priority to some constitutional norms rather than treating all as equally deserving of regulatory attention, is absent.

That should change. It is time to acknowledge the tradeoffs, to take seriously the nature of the system the law of criminal procedure regulates and the ways in which that system can evade or undermine the regulation. In a regime like ours, countermajoritarian restraints on the criminal process can succeed only at a cost, the cost is probably substantial, and it is disproportionately imposed on those who least deserve to bear it. Leaving more of the process to majoritarian institutions might be better, not least for some of the defendants the process is designed to protect.

That need not mean leaving defendants to the mercies of state legislatures and local prosecutors. If constitutional law's response to criminal justice has failed, it has failed not just from too much intervention but from too little as well. Making Gideon a formal right only, without any ancillary funding requirements, has produced a criminal process that is, for poor defendants, a scandal. Courts' reluctance to police legislatures' criminalization and sentencing decisions-coupled with the way those legislative decisions can be used in a system that gives prosecutors blanket authority to choose whom to go after and for what-has produced its own scandals. Defendants' interests might best be protected by less procedure, coupled with a much more activist judicial posture toward funding, the definition of crime, and sentencing-all areas where judges have been loath to take dramatic stands.

This judicial reticence seems to have been motivated by a desire not to trench on the prerogatives of the politicians, a desire to stick to the more lawlike and presumably less contentious ground of process. That the $1960 \mathrm{~s}$ produced a revolution in criminal procedure may testify to the underrated conservatism of Warren Court constitutional thought, to that radical Court's willingness to confine its intervention to conventional categories. ${ }^{254}$ If so, in this area these conservative instincts may have been misplaced-as, perhaps, was the Court's reformist (procedural) zeal. The system might be better off today had Warren and his colleagues worried less about criminal procedure, and more about criminal justice.

254. For an insightful commentary on the conservatism of the Warren Court, see Louis Michacl Seidman, Romer's Radicalism: The Unexpected Revival of Warren Court Activism, 1996 SUP. CT. REV. $67,70-71,86-96,120-21$. 